Supplement of Geosci. Model Dev., 14, 2867-2897, 2021

https://doi.org/10.5194/gmd-14-2867-2021-supplement

(C) Author(s) 2021. CC BY 4.0 License.

(c) (i)

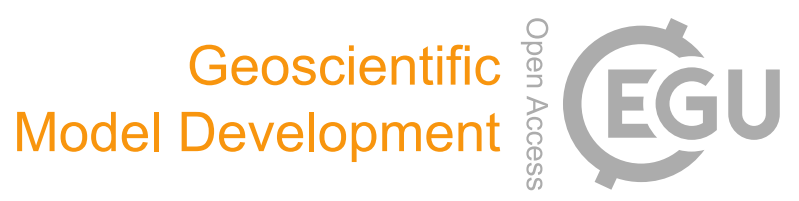

Supplement of

\title{
The Community Multiscale Air Quality (CMAQ) model versions 5.3 and 5.3.1: system updates and evaluation
}

K. Wyat Appel et al.

Correspondence to: K. Wyat Appel (appel.wyat@epa.gov)

The copyright of individual parts of the supplement might differ from the article licence. 
Table S1. New species introduced in AERO7 compared to AERO6. Species 1-21 are new to AERO7i. Other species in AERO7i (including species 22-24) previously existed in AERO6i. All gas-phase semi-volatiles use speciesspecific wet and dry deposition surrogates. Note that underscores are no longer used in species names in any aerosol or non-reactives namelist. For example, SV_ISO1 is now SVISO1 in the non-reactives namelist (i.e. NR*.nml) in CMAQ.

\begin{tabular}{|c|c|c|c|c|c|}
\hline & Species & Phase & Description & Scientific Basis & $\begin{array}{c}\text { Model } \\
\text { Implementation }\end{array}$ \\
\hline 1 & AMT1J & particle & $\begin{array}{l}\text { low volatility particulate matter } \\
\text { from monoterpene photoxidation } \\
\left(\mathrm{OH} \text { and } \mathrm{O}_{3} \text { reaction }\right) \\
\mathrm{C}^{*}=0.01 \mu \mathrm{g} \mathrm{m}^{-3}\end{array}$ & $\begin{array}{l}\text { dark } \alpha \text {-pinene } \\
\text { ozonolysis (Saha and } \\
\text { Grieshop, } \\
\text { 2016,ES\&T) }\end{array}$ & $\begin{array}{l}\text { Xu et al., } \\
2018, A C P\end{array}$ \\
\hline 2 & AMT2J & particle & $\begin{array}{l}\text { low volatility particulate matter } \\
\text { from monoterpene photoxidation } \\
\left(\mathrm{OH} \text { and } \mathrm{O}_{3} \text { reaction }\right) \\
\mathrm{C}^{*}=0.1 \mu \mathrm{g} \mathrm{m}^{-3}\end{array}$ & $\begin{array}{l}\text { dark } \alpha \text {-pinene } \\
\text { ozonolysis (Saha and } \\
\text { Grieshop, } \\
2016, E S \& T)\end{array}$ & $\begin{array}{l}\text { Xu et al., } \\
2018, A C P\end{array}$ \\
\hline 3 & AMT3J & particle & $\begin{array}{l}\text { semivolatile particulate matter } \\
\text { from monoterpene photoxidation } \\
\left(\mathrm{OH} \text { and } \mathrm{O}_{3} \text { reaction }\right) \\
\mathrm{C}^{*}=1 \mu \mathrm{g} \mathrm{m}^{-3}\end{array}$ & $\begin{array}{l}\text { dark } \alpha \text {-pinene } \\
\text { ozonolysis (Saha and } \\
\text { Grieshop, } \\
2016, E S \& T)\end{array}$ & $\begin{array}{l}\text { Xu et al., } \\
2018, A C P\end{array}$ \\
\hline 4 & AMT4J & particle & $\begin{array}{l}\text { semivolatile particulate matter } \\
\text { from monoterpene photoxidation } \\
\left(\mathrm{OH} \text { and } \mathrm{O}_{3} \text { reaction }\right) \\
\mathrm{C}^{*}=10 \mu \mathrm{g} \mathrm{m}^{-3}\end{array}$ & $\begin{array}{l}\text { dark } \alpha \text {-pinene } \\
\text { ozonolysis (Saha and } \\
\text { Grieshop, } \\
\text { 2016, ES\&T) }\end{array}$ & $\begin{array}{l}\text { Xu et al., } \\
2018, A C P\end{array}$ \\
\hline 5 & AMT5J & particle & $\begin{array}{l}\text { semivolatile particulate matter } \\
\text { from monoterpene photoxidation } \\
\left(\mathrm{OH} \text { and } \mathrm{O}_{3} \text { reaction }\right) \\
\mathrm{C}^{*}=100 \mu \mathrm{g} \mathrm{m}^{-3}\end{array}$ & $\begin{array}{l}\text { dark } \alpha \text {-pinene } \\
\text { ozonolysis (Saha and } \\
\text { Grieshop, } \\
2016, E S \& T)\end{array}$ & $\begin{array}{l}\text { Xu et al., } \\
2018, A C P\end{array}$ \\
\hline 6 & AMT6J & particle & $\begin{array}{l}\text { semivolatile particulate matter } \\
\text { from monoterpene photoxidation } \\
\left(\mathrm{OH} \text { and } \mathrm{O}_{3} \text { reaction }\right) \\
\mathrm{C}^{*}=1000 \mu \mathrm{g} \mathrm{m}^{-3}\end{array}$ & $\begin{array}{l}\text { dark } \alpha \text {-pinene } \\
\text { ozonolysis (Saha and } \\
\text { Grieshop, } \\
2016, E S \& T)\end{array}$ & $\begin{array}{l}\text { Xu et al., } \\
2018, A C P\end{array}$ \\
\hline 7 & SVMT1 & gas & $\begin{array}{l}\text { low volatility gas from } \\
\text { monoterpene photoxidation }(\mathrm{OH} \\
\text { and } \mathrm{O}_{3} \text { reaction), } \mathrm{C}^{*}=0.01 \mu \mathrm{g} \mathrm{m}^{-3}\end{array}$ & $\begin{array}{l}\text { dark } \alpha \text {-pinene } \\
\text { ozonolysis (Saha and } \\
\text { Grieshop, } \\
\text { 2016,ES\&T) }\end{array}$ & $\begin{array}{l}\text { Xu et al., } \\
2018, A C P\end{array}$ \\
\hline 8 & SVMT2 & gas & $\begin{array}{l}\text { low volatility gas from } \\
\text { monoterpene photoxidation }(\mathrm{OH} \\
\text { and } \mathrm{O}_{3} \text { reaction), } \mathrm{C}^{*}=0.1 \mu \mathrm{g} \mathrm{m}^{-3}\end{array}$ & $\begin{array}{l}\text { dark } \alpha \text {-pinene } \\
\text { ozonolysis (Saha and } \\
\text { Grieshop, } \\
2016, E S \& T)\end{array}$ & $\begin{array}{l}\text { Xu et al., } \\
2018, A C P\end{array}$ \\
\hline 9 & SVMT3 & gas & $\begin{array}{l}\text { semivolatile gas from } \\
\text { monoterpene photoxidation }(\mathrm{OH} \\
\text { and } \mathrm{O}_{3} \text { reaction), } \mathrm{C}^{*}=1 \mu \mathrm{g} \mathrm{m}^{-3}\end{array}$ & $\begin{array}{l}\text { dark } \alpha \text {-pinene } \\
\text { ozonolysis (Saha and } \\
\text { Grieshop, } \\
\text { 2016,ES\&T) }\end{array}$ & $\begin{array}{l}\text { Xu et al., } \\
2018, A C P\end{array}$ \\
\hline
\end{tabular}




\begin{tabular}{|c|c|c|c|c|c|}
\hline & Species & Phase & Description & Scientific Basis & $\begin{array}{c}\text { Model } \\
\text { Implementation }\end{array}$ \\
\hline 10 & SVMT4 & gas & $\begin{array}{l}\text { semivolatile gas from } \\
\text { monoterpene photoxidation }(\mathrm{OH} \\
\left.\text { and } \mathrm{O}_{3} \text { reaction }\right), \mathrm{C}^{*}=10 \mu \mathrm{g} \mathrm{m}^{-3}\end{array}$ & $\begin{array}{l}\text { dark } \alpha \text {-pinene } \\
\text { ozonolysis (Saha and } \\
\text { Grieshop, } \\
2016, E S \& T)\end{array}$ & $\begin{array}{l}\text { Xu et al., } \\
2018, A C P\end{array}$ \\
\hline 11 & SVMT5 & gas & $\begin{array}{l}\text { semivolatile gas from } \\
\text { monoterpene photoxidation }(\mathrm{OH} \\
\text { and } \mathrm{O}_{3} \text { reaction), } \mathrm{C}^{*}=100 \mu \mathrm{g} \mathrm{m}^{-3}\end{array}$ & $\begin{array}{l}\text { dark } \alpha \text {-pinene } \\
\text { ozonolysis (Saha and } \\
\text { Grieshop, } \\
2016, E S \& T)\end{array}$ & $\begin{array}{l}\text { Xu et al., } \\
2018, A C P\end{array}$ \\
\hline 12 & SVMT6 & gas & $\begin{array}{l}\text { semivolatile gas from } \\
\text { monoterpene photoxidation }(\mathrm{OH} \\
\text { and } \mathrm{O}_{3} \text { reaction), } \mathrm{C}^{*}=1000 \mu \mathrm{g} \mathrm{m}^{-3}\end{array}$ & $\begin{array}{l}\text { dark } \alpha \text {-pinene } \\
\text { ozonolysis (Saha and } \\
\text { Grieshop, } \\
2016, E S \& T)\end{array}$ & $\begin{array}{l}\text { Xu et al., } \\
2018, A C P\end{array}$ \\
\hline 13 & AORGH2OJ & particle & $\begin{array}{l}\text { water associated with organic } \\
\text { species of particulate matter }\end{array}$ & $\begin{array}{l}\text { hygroscopicity } \\
\text { parameters (Petters } \\
\text { and Kreidenweis, } \\
2007, A C P \text { ) as a } \\
\text { function of degree of } \\
\text { oxygenation (Lambe et } \\
\text { al., } 2011, A C P)\end{array}$ & $\begin{array}{l}\text { Pye et al., } \\
2017, A C P\end{array}$ \\
\hline 14 & AAVB1J & particle & $\begin{array}{l}\text { low volatility organic particulate } \\
\text { matter from oxidation of } \\
\text { anthropogenic VOCs (benzene, } \\
\text { toluene, xylene, PAHs, alkanes) }\end{array}$ & $\begin{array}{l}\text { GEOS-Chem VBS } \\
\text { parameterization (Pye } \\
\text { et al., 2010, } A C P \text { ) for } \\
\text { aromatics and PAHs } \\
\text { with long-chain } \\
\text { alkanes following Pye } \\
\text { and Pouliot } \\
\text { (2012, ES\&T) but with } \\
\text { Presto et al. } \\
(2010, E S \& T) \text { VBS } \\
\text { fits; all underlying } \\
\text { experimental datasets } \\
\text { are the same as } \\
\text { in aero6 }\end{array}$ & $\begin{array}{l}\text { Qin et al., in } \\
\text { prep. }\end{array}$ \\
\hline 15 & AAVB2J & particle & $\begin{array}{l}\text { semivolatile organic particulate } \\
\text { matter from oxidation of } \\
\text { anthropogenic VOCs (benzene, } \\
\text { toluene, xylene, PAHs, alkanes) }\end{array}$ & see AAVB1J & $\begin{array}{l}\text { Qin et al., in } \\
\text { prep. }\end{array}$ \\
\hline 16 & AAVB3J & particle & $\begin{array}{l}\text { semivolatile organic particulate } \\
\text { matter from oxidation of } \\
\text { anthropogenic VOCs (benzene, } \\
\text { toluene, xylene, PAHs, alkanes) }\end{array}$ & see AAVB1J & $\begin{array}{l}\text { Qin et al., in } \\
\text { prep. }\end{array}$ \\
\hline 17 & AAVB4J & particle & $\begin{array}{l}\text { semivolatile organic particulate } \\
\text { matter from oxidation of } \\
\text { anthropogenic VOCs (benzene, } \\
\text { toluene, xylene, PAHs, alkanes) }\end{array}$ & see AAVB1J & $\begin{array}{l}\text { Qin et al., in } \\
\text { prep. }\end{array}$ \\
\hline
\end{tabular}




\begin{tabular}{|c|c|c|c|c|c|}
\hline & Species & Phase & Description & Scientific Basis & $\begin{array}{c}\text { Model } \\
\text { Implementation }\end{array}$ \\
\hline 18 & SVAVB1 & gas & $\begin{array}{l}\text { low volatility organic gas from } \\
\text { oxidation of anthropogenic VOCs } \\
\text { (benzene, toluene, xylene, PAHs, } \\
\text { alkanes) }\end{array}$ & see AAVB1J & $\begin{array}{l}\text { Qin et al., in } \\
\text { prep. }\end{array}$ \\
\hline 19 & SVAVB2 & gas & $\begin{array}{l}\text { semivolatile organic gas from } \\
\text { oxidation of anthropogenic VOCs } \\
\text { (benzene, toluene, xylene, PAHs, } \\
\text { alkanes) }\end{array}$ & see AAVB1J & $\begin{array}{l}\text { Qin et al., in } \\
\text { prep. }\end{array}$ \\
\hline 20 & SVAVB3 & gas & $\begin{array}{l}\text { semivolatile organic gas from } \\
\text { oxidation of anthropogenic VOCs } \\
\text { (benzene, toluene, xylene, PAHs, } \\
\text { alkanes) }\end{array}$ & see AAVB1J & $\begin{array}{l}\text { Qin et al., in } \\
\text { prep. }\end{array}$ \\
\hline 21 & SVAVB4 & gas & $\begin{array}{l}\text { semivolatile organic gas from } \\
\text { oxidation of anthropogenic VOCs } \\
\text { (benzene, toluene, xylene, PAHs, } \\
\text { alkanes) }\end{array}$ & see AAVB1J & $\begin{array}{l}\text { Qin et al., in } \\
\text { prep. }\end{array}$ \\
\hline 22 & MTNO3 & gas & $\begin{array}{l}\text { organic nitrates from } \\
\text { monoterpene oxidation }\end{array}$ & $\begin{array}{l}\text { gas-phase SAPRC } \\
\text { yields (should not be } \\
\text { counted as gas-phase } \\
\text { organic nitrate for } \\
\text { evaluation purposes in } \\
\text { CB6r3 mechanisms) }\end{array}$ & $\begin{array}{l}\text { Pye et al., } \\
2015, E S \& T\end{array}$ \\
\hline 23 & AMTNO3J & particle & $\begin{array}{l}\text { semivolatile organic nitrates from } \\
\text { monoterpene oxidation }\end{array}$ & $\begin{array}{l}\text { Fry et al. }(2009, A C P) \\
\text { for vapor pressure of } \\
\text { monoterpene organic } \\
\text { nitrates }\end{array}$ & $\begin{array}{l}\text { Pye et al., } \\
2015, E S \& T\end{array}$ \\
\hline 24 & AMTHYDJ & particle & $\begin{array}{l}\text { organic pseudo-hydrolysis } \\
\text { accretion product from } \\
\text { monoterpene organic nitrates } \\
\text { (AMTNO3J) }\end{array}$ & $\begin{array}{l}\text { Boyd et al. } \\
(2015, A C P) \text { for } \\
\text { hydrolysis timescale } \\
\text { for tertiary nitrates, but } \\
\text { applied to all MTNO3 } \\
\text { following Pye et al. } \\
(2015, E S \& T)\end{array}$ & $\begin{array}{l}\text { Pye et al., } \\
2015, E S \& T\end{array}$ \\
\hline
\end{tabular}

*Species in AERO6/6i that are deprecated in AERO7/7i (these species should NOT appear in an AERO7/7i namelist): ATRP1J, ATRP2J, SV_TRP1, SV_TRP2, ABNZ1J, ABNZ2J, ABNZ3J, SV_BNZ1, SV_BNZ2, AXYL1J, AXYL2J, AXYL3J, SV_X̄XY1, SV_XY'XL2, ATOL1J, ATOL2J, ATOL3J, SV_TOL1, SV_TOL2, APAH1J, APAH2J, APAH3J, SV_PAH1, SV_PAH2, AALK1J, AALK2J, SV_ALK1, SV_ALK2 
Table S2. Namelist options used for WRF version 3.8 simulation.

$$
\begin{aligned}
& \text { \&time_control } \\
& \text { start_year } \quad=2015 \text {, } \\
& \text { start_month } \quad=12 \text {, } \\
& \text { start_day } \quad=21 \text {, } \\
& \text { start_hour } \quad=00 \text {, } \\
& \text { start_minute } \quad=00 \text {, } \\
& \text { start_second } \quad=00 \text {, } \\
& \text { end_year } \quad=2015 \text {, } \\
& \text { end_month } \quad=12 \text {, } \\
& \text { end_day } \quad=27 \text {, } \\
& \text { end_hour } \quad=00 \text {, } \\
& \text { end_minute } \quad=01 \text {, } \\
& \text { end second } \quad=00 \text {, } \\
& \text { interval_seconds } \quad=10800 \text {, } \\
& \text { input_from_file =.true., } \\
& \text { history_interval }=60 \text {, } \\
& \text { frames_per_outfile } \quad=24 \text {, } \\
& \text { restart =.FALSE., } \\
& \text { restart_interval } \quad=1440 \text {, } \\
& \text { io_form_history } \quad=2 \\
& \text { io_form_restart } \quad=2 \\
& \text { io_form_input } \quad=2 \\
& \text { io_form_boundary } \quad=2 \\
& \text { debug_level }=0 \\
& \text { io_form_auxinput2 } \quad=2 \\
& \text { io_form_auxinput4 }=2 \\
& \text { auxinput1_inname } \quad=\text { "metoa_em.d01.<date }>\text { " } \\
& \text { auxinput4_inname = "wrflowinp_d01" } \\
& \text { auxinput4_interval } \quad=180 \\
& \text { auxinput4_end_h } \quad=9025 \\
& \text { write hist_at_0h_rst } \quad=\text {.true., } \\
& \text { io form auxinputs } \quad=2 \text {, } \\
& \text { auxinput8_inname } \quad=\text { 'LTNG_<year }><\text { month }>\text {.nc', } \\
& \text { frames_per_auxinput8 } \quad=1600 \text {, } \\
& \text { auxinput8_interval_m }=30 \text {, } \\
& \text { auxinput8_end_h } \quad=9999 \text {, } \\
& \text { / } \\
& \text { time_step } \\
& \text { time_step_fract_num } \\
& \text { time_step_fract_den } \\
& =60 \text {, } \\
& =0 \text {, } \\
& =1 \text {, } \\
& =\text {.false. } \\
& \begin{array}{l}
\text { use_adaptive_time_step } \\
\text { max_dom }
\end{array} \\
& \text { s_we } \quad=1 \text {, } \\
& \text { e_we } \quad=472 \text {, } \\
& \text { s_sn } \quad=1 \text {, } \\
& \text { e_sn } \quad=312 \text {, } \\
& \text { s_vert } \quad=1 \text {, } \\
& \text { e_vert }=36 \text {, } \\
& \text { p_top_requested } \quad=5000 \text {, } \\
& \text { eta_levels } \quad=1.000,0.9975,0.995,0.990,0.985 \text {, } \\
& 0.980,0.970,0.960,0.950 \text {, } \\
& 0.940,0.930,0.920,0.910 \text {, }
\end{aligned}
$$




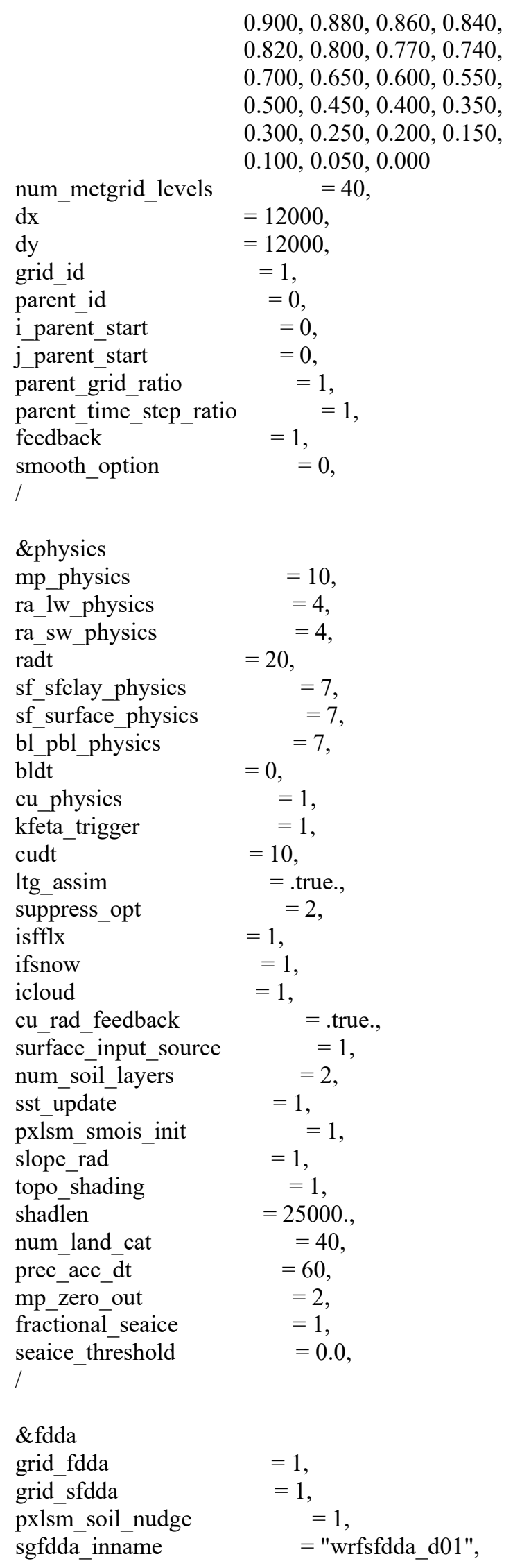




$$
\begin{aligned}
& \text { sgfdda_end_h } \quad=9025 \text {, } \\
& \text { sgfdda interval_m } \quad=180 \text {, } \\
& \text { sgfdda interval } \quad=10800 \text {, } \\
& \text { gfdda_inname = "wrffdda_d }<\text { domain }>\text { ", } \\
& \text { gfdda_end_h } \quad=9025 \text {, } \\
& \text { gfdda_interval_m }=180 \text {, } \\
& \text { fgdt } \quad=0 \text {, } \\
& \text { if_no_pbl_nudging_uv } \quad=1 \text {, } \\
& \text { if no pbl nudging t } \quad=1 \text {, } \\
& \text { if no pbl nudging } \mathrm{q} \quad=1 \text {, } \\
& \text { if_zfac_uv }=0 \text {, } \\
& \text { k_zfac_uv } \quad=13 \text {, } \\
& \text { if_zfac_t } \quad=0 \text {, } \\
& \text { k_zfac_t } \quad=13 \text {, } \\
& \text { if_zfac_q } \quad=0 \text {, } \\
& \text { k_zfac_q } \quad=13 \text {, } \\
& \text { guv }=0.0001 \text {, } \\
& \text { gt } \quad=0.0001 \text {, } \\
& \text { gq } \quad=0.00001 \text {, } \\
& \text { guv_sfc } \quad=0.0000 \text {, } \\
& \text { gt_sfc } \quad=0.0000 \text {, } \\
& \text { gq_sfc } \quad=0.0000 \text {, } \\
& \text { if_ramping } \quad=0 \text {, } \\
& \text { dtramp_min } \quad=60.0 \text {, } \\
& \text { io_form_gfdda } \quad=2 \text {, } \\
& \text { rinblw } \quad=250.0 \\
& \text { / } \\
& =1 \text {, } \\
& =1 \text {, } \\
& =4 \text {, } \\
& =2 \text {, } \\
& =0.12 \text {, } \\
& =3 \text {, } \\
& =290 \text {. } \\
& \text { base temp } \\
& =5000 \text {. } \\
& \text { zdamp } \\
& \text { dampcoef } \\
& \text { khdif } \\
& =0.05 \text {, } \\
& \text { kvdif } \\
& =0 \text {, } \\
& =0 \text {, } \\
& =\text {.true., } \\
& =2 \text {, } \\
& =2 \text {, } \\
& =2 \text {, }
\end{aligned}
$$

$\begin{array}{llr}\text { dfi_opt } & =0 & \\ \text { dfi_nfilter } & =7 & \\ \text { dfi_write_filtered_input } & & =\text {.true. } \\ \text { dfi_write_dfi_history } & =. \text { false. } \\ \text { dfi_cutoff_seconds } & =60 \\ \text { dfi_time_dim } & =1000 \\ \text { dfi_bckstop_year } & =2006 \\ \text { dfi_bckstop_month } & =08 \\ \text { dfi_bckstop_day } & =04\end{array}$




\begin{tabular}{lc} 
dfi_bckstop_hour & $=12$ \\
dfi_bckstop_minute & $=00$ \\
dfi_bckstop_second & $=00$ \\
dfi_fwdstop_year & $=2006$ \\
dfi_fwdstop_month & $=08$ \\
dfi_fwdstop_day & $=04$ \\
dfi_fwdstop_hour & $=13$ \\
dfi_fwdstop_minute & $=00$ \\
dfi_fwdstop_second & $=00$ \\
\hline
\end{tabular}

\section{\&bdy_control}

spec_bdy_width

spec_zone

$=5$,

relax_zone

$=1$,

specified

$=4$,

nested

$=$.true.,

I

$=$.false.,

\&grib2

/

\&namelist_quilt

nio_tasks_per_group $=0$, nio_groups $=1$, 
Table S3. Namelist options used in WRF version 4.1.1 simulation.

\&time_control

$$
\text { start_year }
$$

start_month

start_day

start_hour

start minute

start_second

end year

end month

end_day

end hour

end minute

end second

interval_seconds

input_from_file

history_interval

frames_per_outfile

restart

restart interval

write_hist_at_0h_rst

io_form_history

io_form_restart

io_form_input

io_form_boundary

io_form_auxinput2

io_form_auxinput4

io_form_auxinput8

debug_level

auxinput1_inname

auxinput4_inname

auxinput4 interval

auxinput4_end_h

auxinput8_inname

auxinput8 interval

auxinput8_end_h

frames_per_auxinput8

reset_simulation_start

iofields filename

force_use_old_data

$$
\begin{aligned}
& =\$ Y S \\
& =\$ \mathrm{MS} \\
& =\$ \mathrm{DS} \\
& =00 \\
& =00 \text {, } \\
& =00 \text {, } \\
& =\$ \mathrm{YE} \\
& =\$ \mathrm{ME} \\
& =\$ \mathrm{DE} \\
& =00 \\
& =00 \text {, } \\
& =00 \text {, } \\
& =10800 \\
& =\text {.true., } \\
& =60 \text {, } \\
& =24 \text {, } \\
& =\text {.true. } \\
& =1440 \text {, } \\
& =\text {.true., } \\
& =2 \\
& =2 \\
& =2 \\
& =2 \\
& =2 \\
& =2 \\
& =2 \text {, } \\
& =0 \\
& =\text { "met_em.d01.<date }>\text { " } \\
& =\text { "wrflowinp_d01" } \\
& =180 \\
& =999999999 \\
& =\text { "LIGHTNING" } \\
& =30 \\
& =999999999 \\
& =7344 \text {, } \\
& =\text {.false., } \\
& =\text { "output.var.txt" } \\
& =\text {.true. }
\end{aligned}
$$

$$
\text { I }
$$

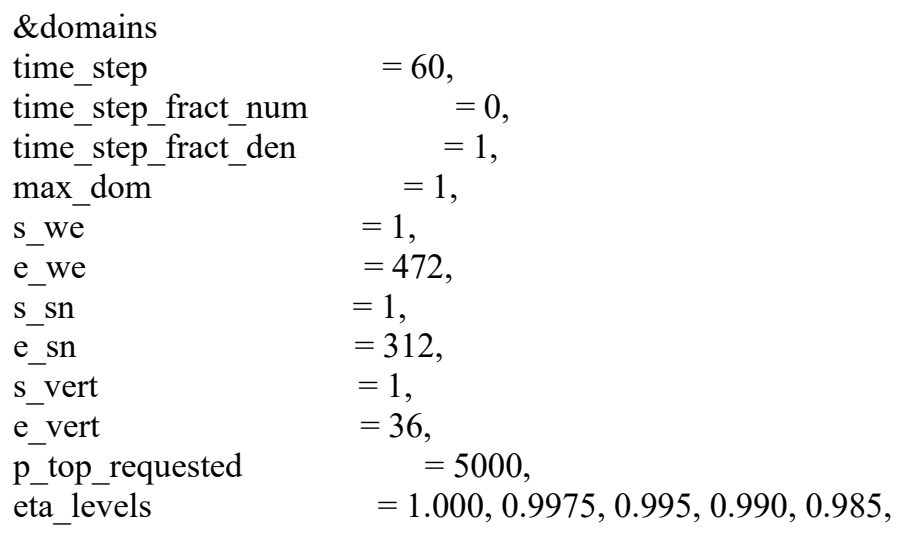




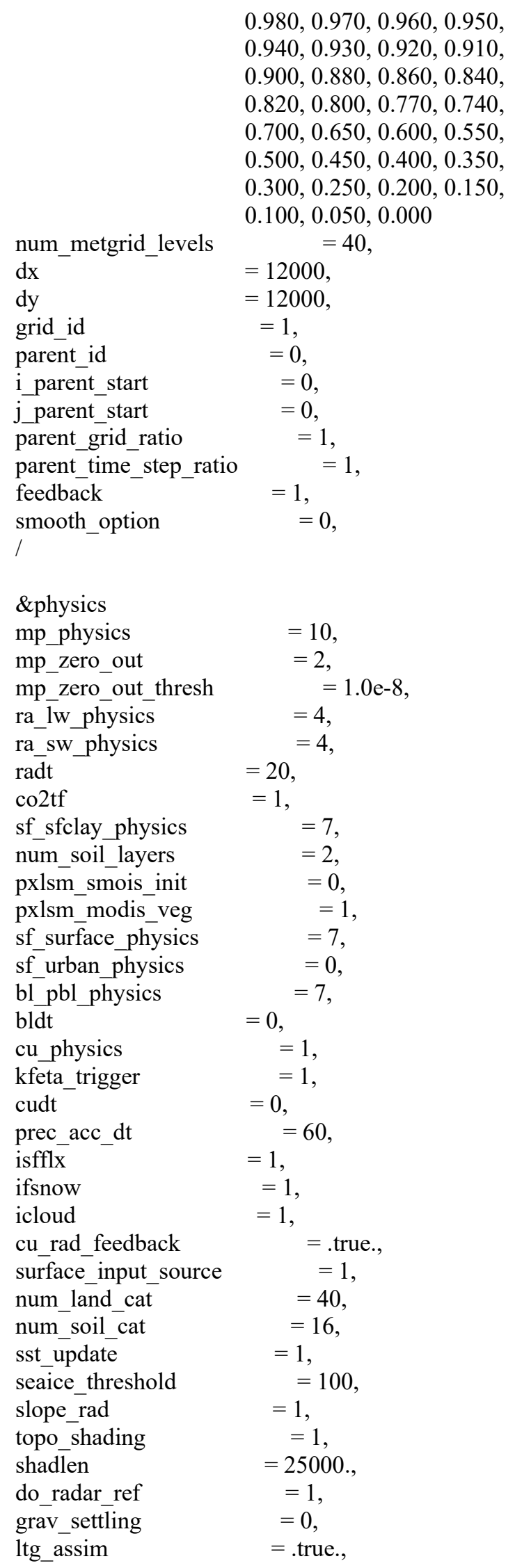




$$
\begin{aligned}
& =1 \text {, } \\
& =4 \text {, } \\
& =2 \text {, } \\
& =0.12 \text {, } \\
& =3 \text {, } \\
& =290 \text {. } \\
& =5000 \text {., } \\
& =0.05 \text {, } \\
& =0 \text {, } \\
& =0 \text {, } \\
& =\text {.true., } \\
& =2 \text {, } \\
& =2 \text {, } \\
& =2 \text {, }
\end{aligned}
$$




$\begin{array}{lc}\text { spec_zone } & =1, \\ \text { relax_zone } & =4, \\ \text { specified } & =. \text { true., } \\ \text { spec_exp } & =0.0, \\ \text { nested } & =\text {.false., } \\ / & \end{array}$

\&grib2

\&namelist_quilt

nio_tasks_per_group $=0$, nio_groups $=1$, 


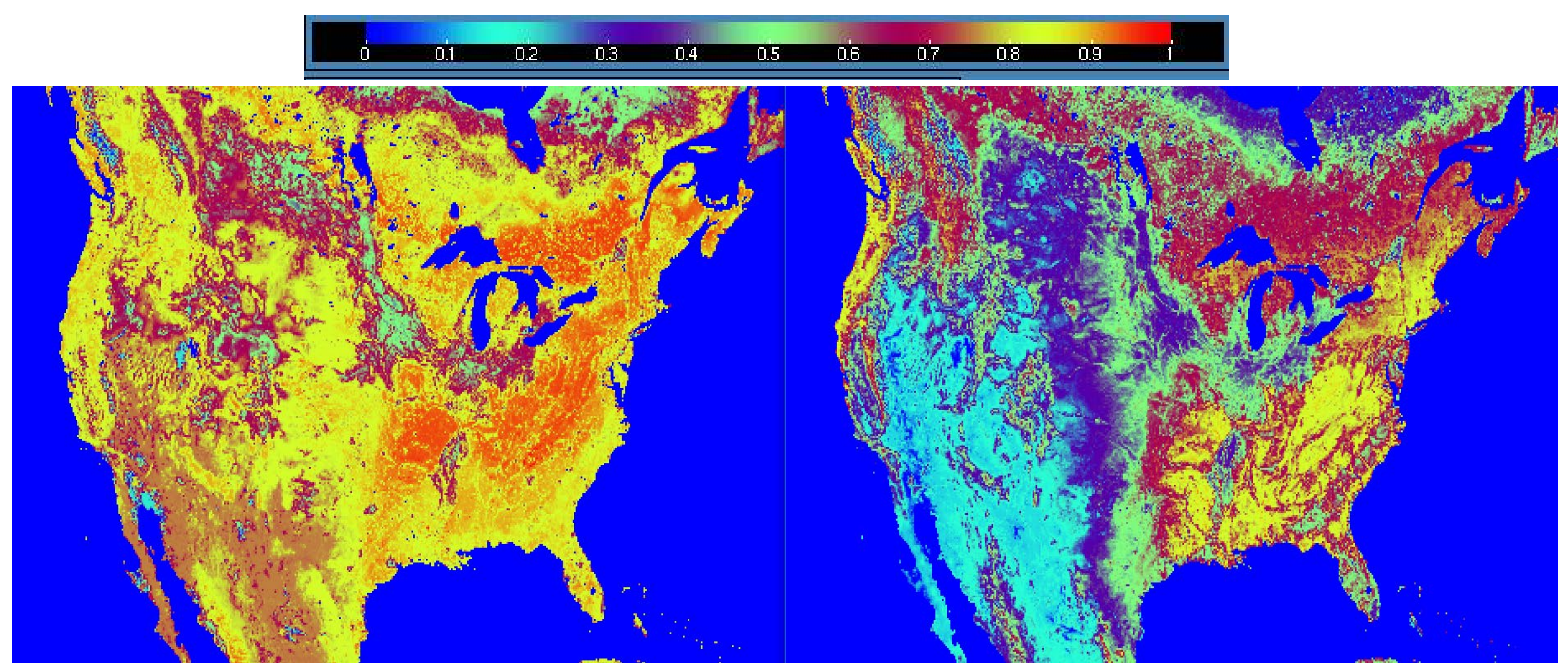

Figure S1. Vegetation Fraction (VF) on June 1, 2016 from WRF38 (left) and WRF411 (right). 


\section{U.S. Climate Regions}

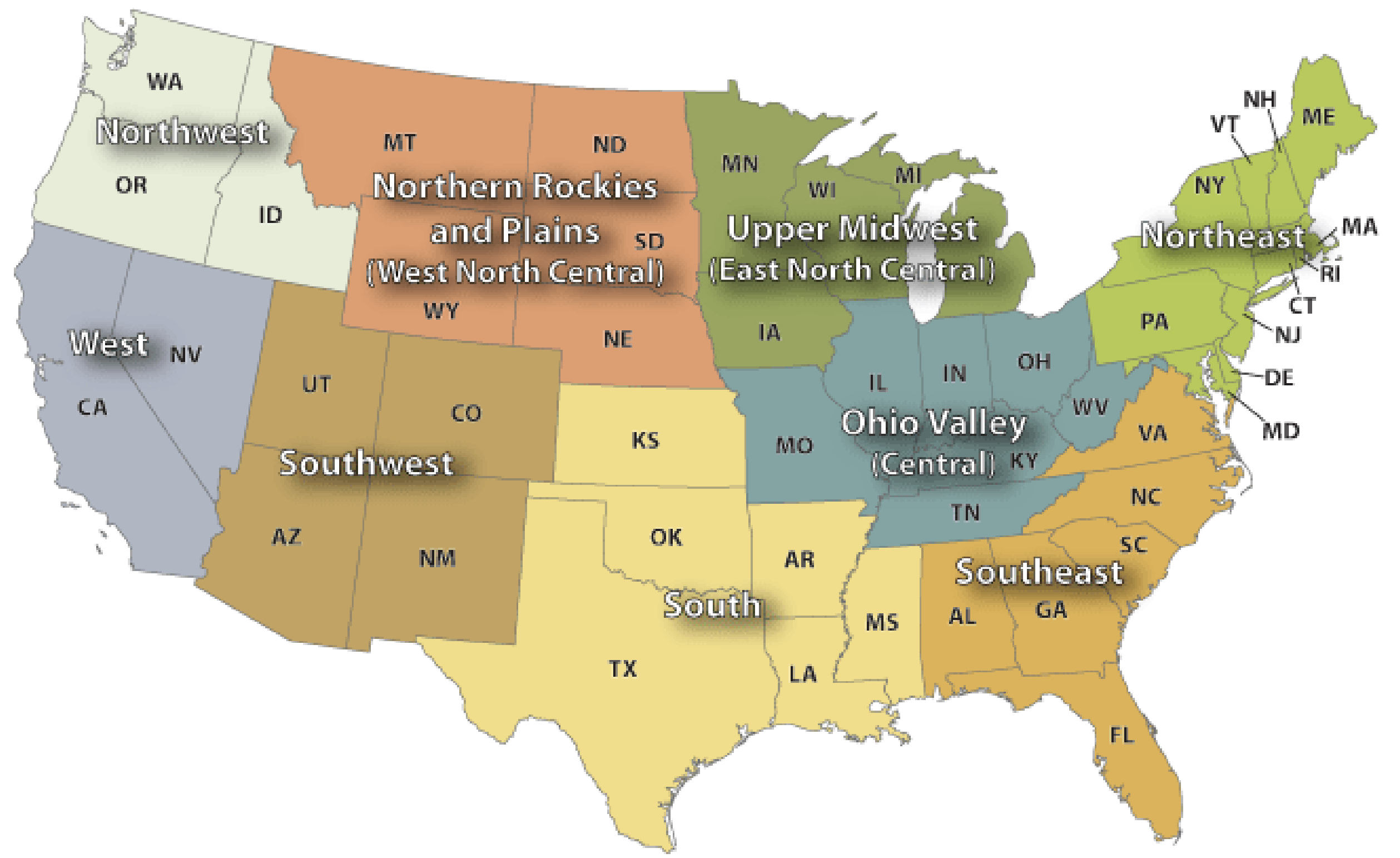

Figure S2. Map of the NOAA U.S. climate regions. Image source: https://www.ncdc.noaa.gov/monitoring-references/maps/us-climateregions.php. 


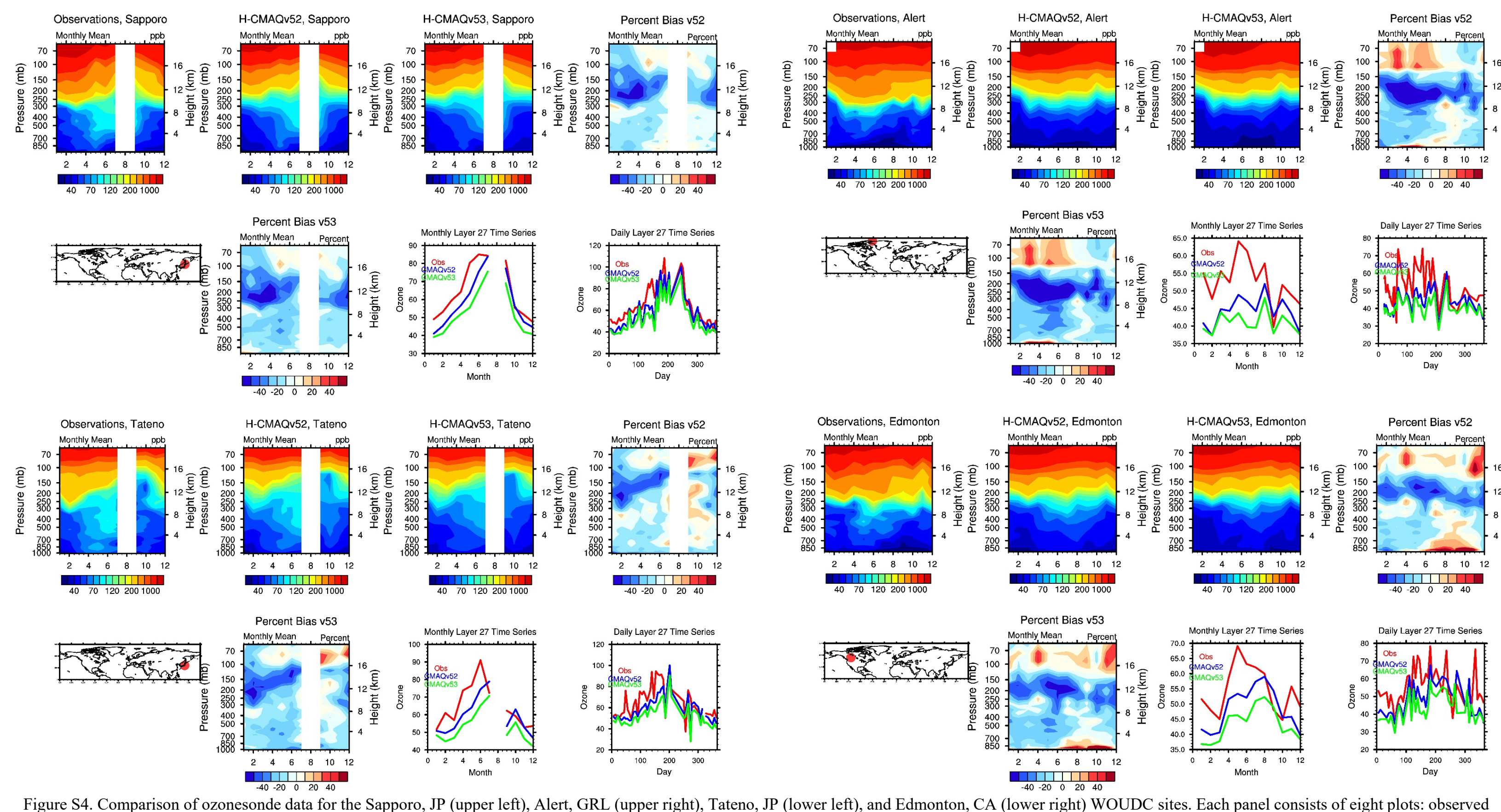

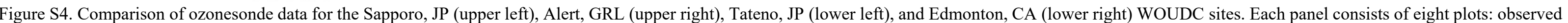

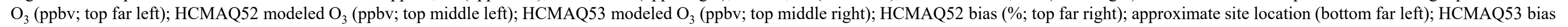
(\%; bottom middle left); layer 27 monthly average $\mathrm{O}_{3}$ time series (ppbv; bottom middle right); layer 27 daily average $\mathrm{O}_{3}$ time series (ppbv; bottom far right). 


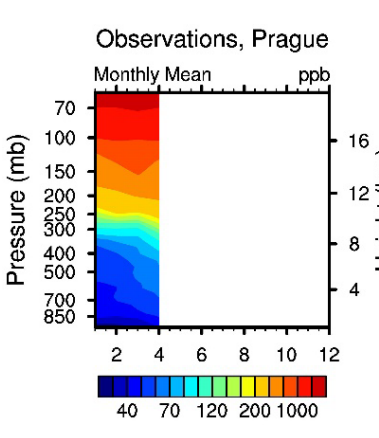

H-CMAQv52, Prague
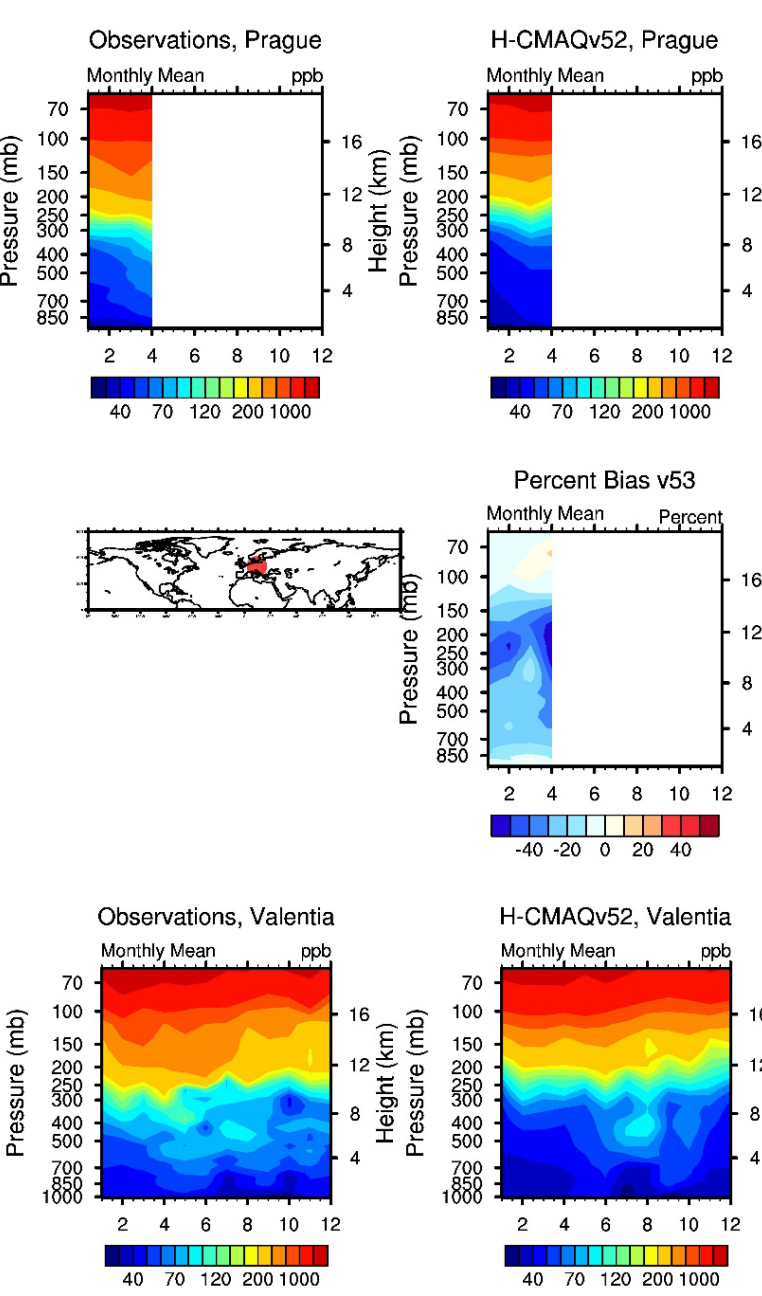

Percent Bias v53

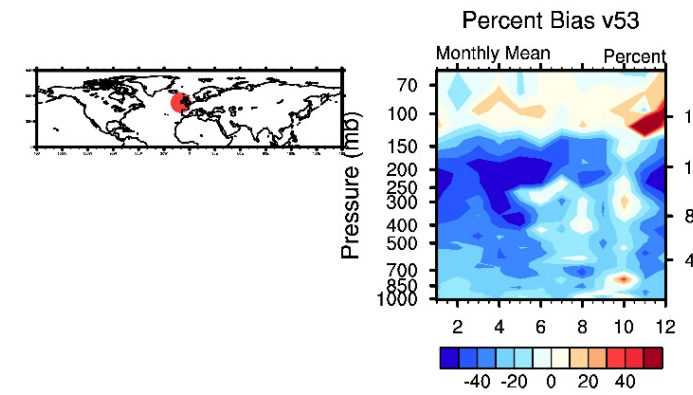

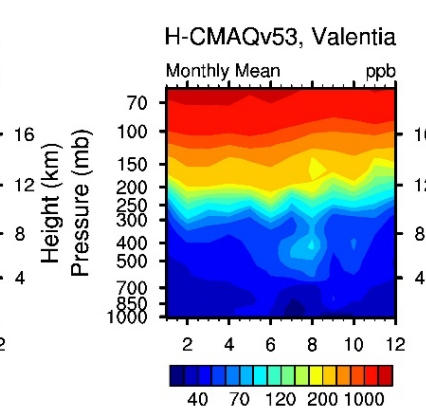

Percent Bias v52
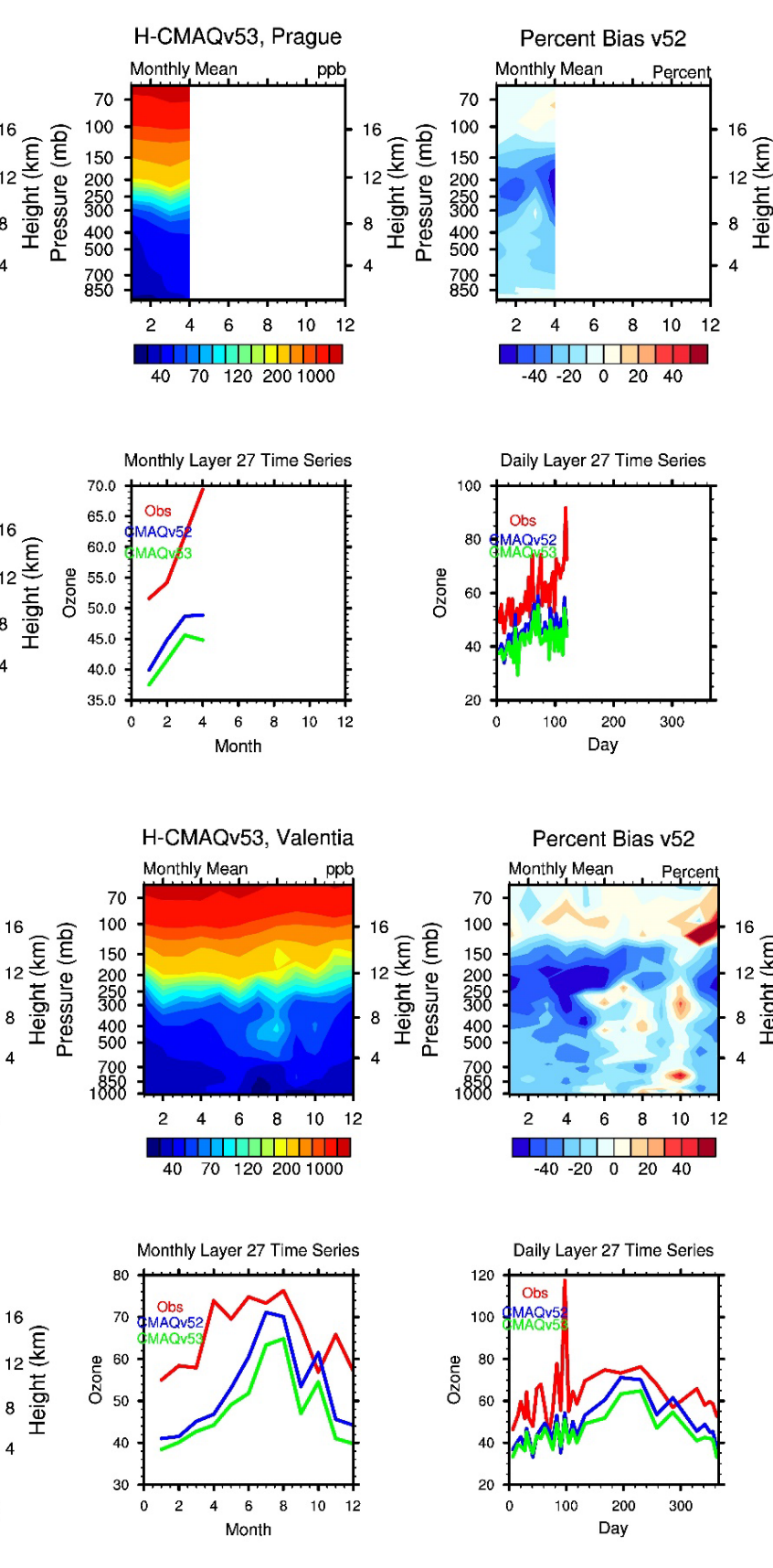
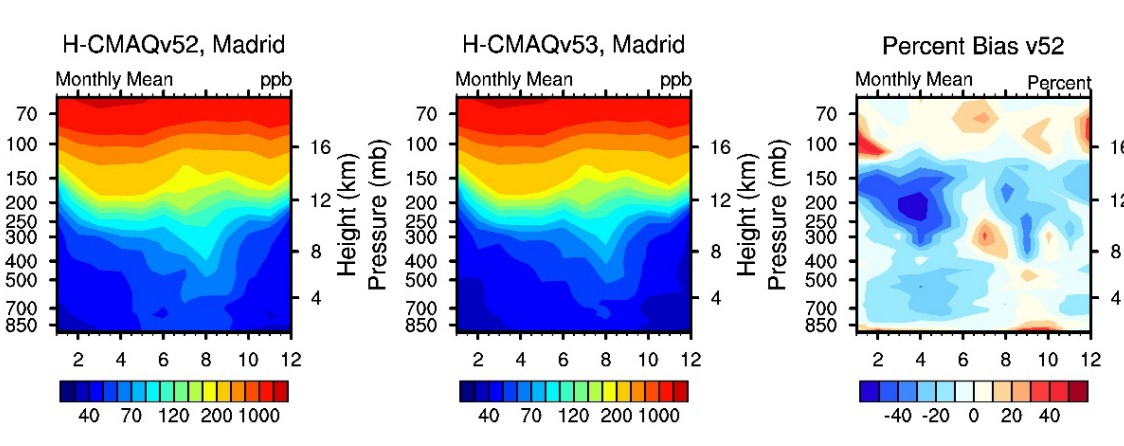

Percent Bias v53
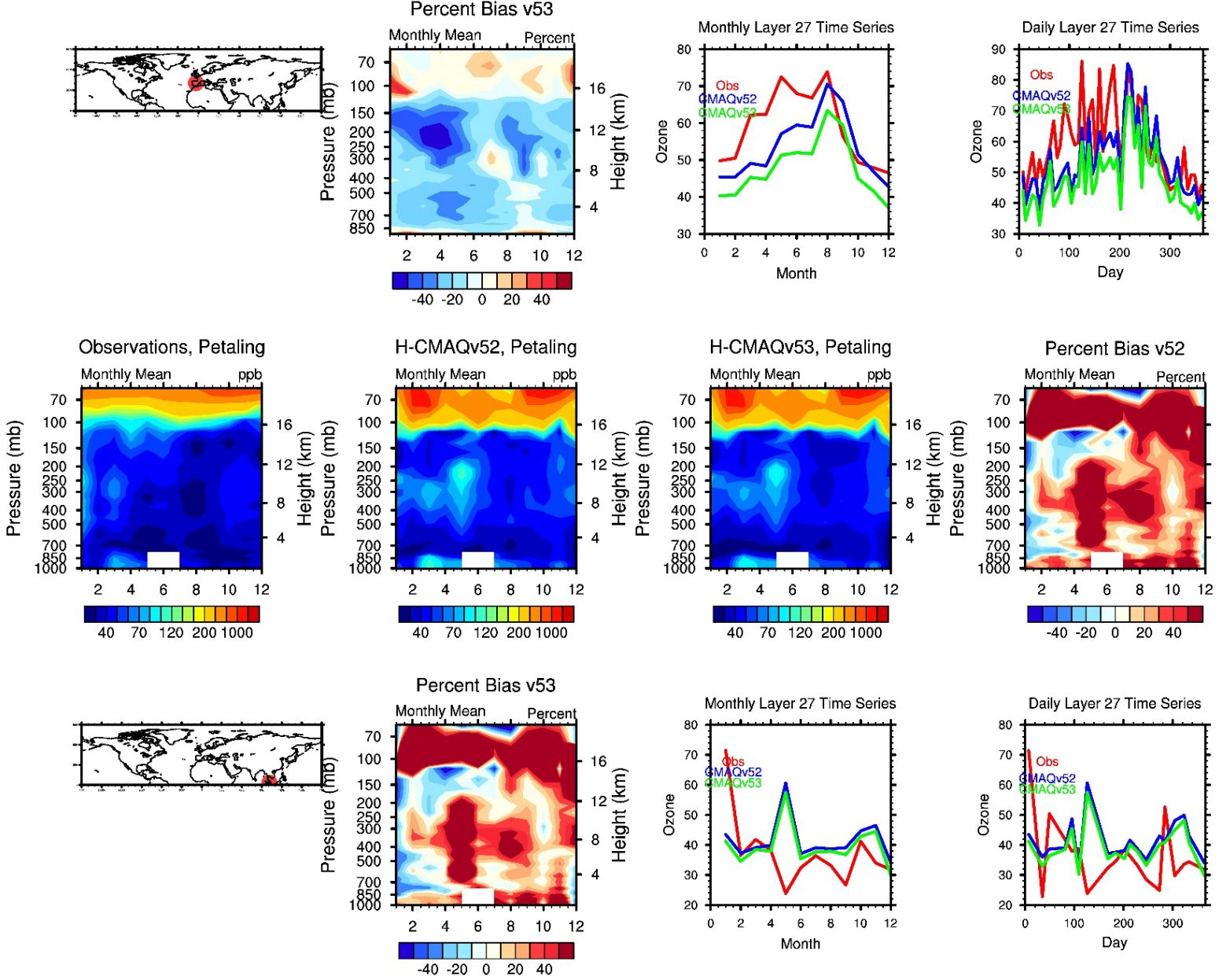

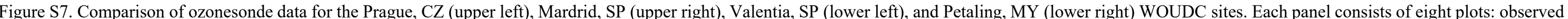

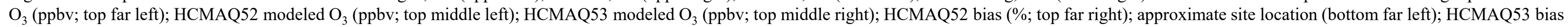
(\%; bottom middle left); layer 27 monthly average $\mathrm{O}_{3}$ time series (ppbv; bottom middle right); layer 27 daily average $\mathrm{O}_{3}$ time series (ppbv; bottom far right). 


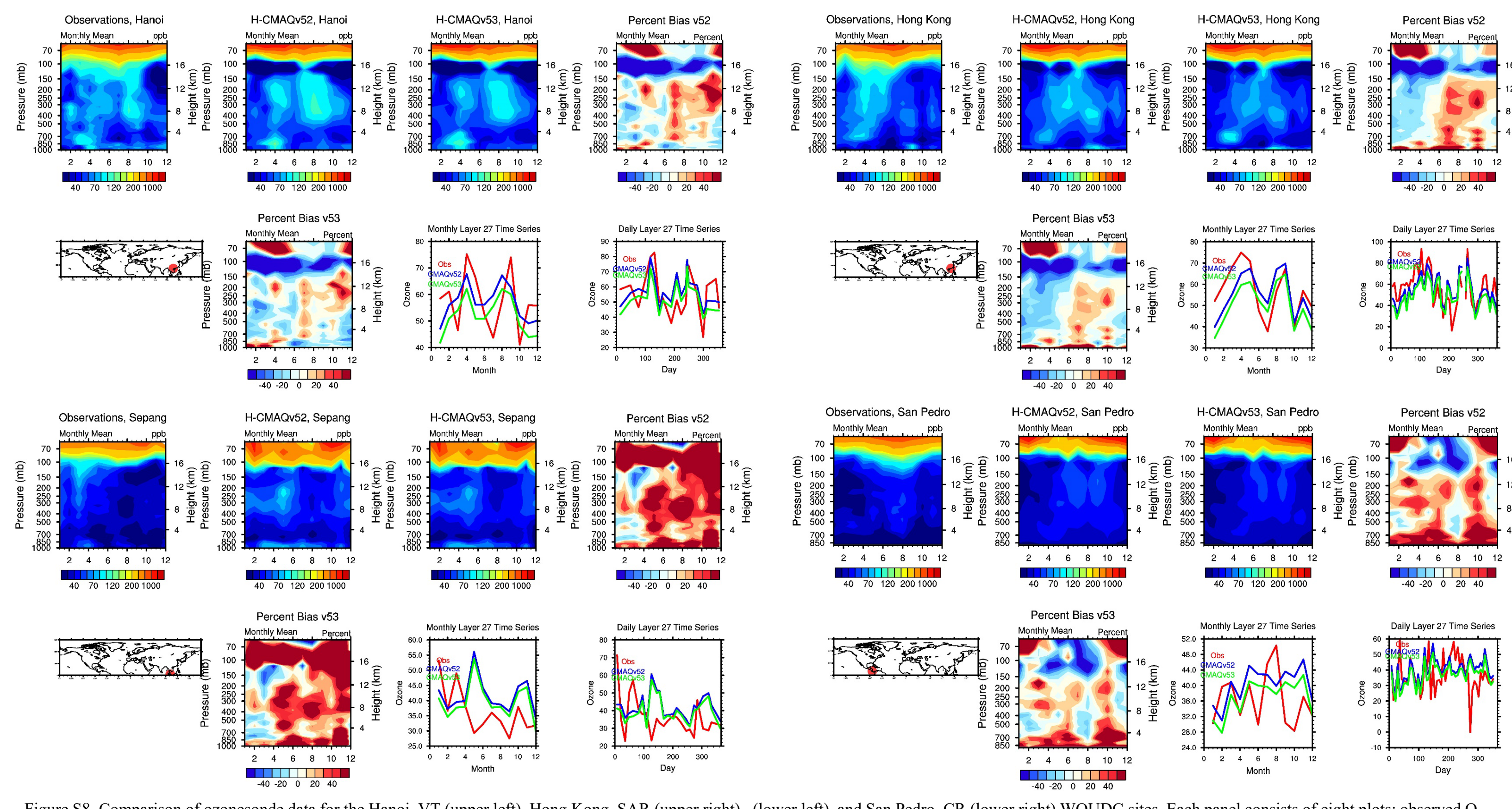

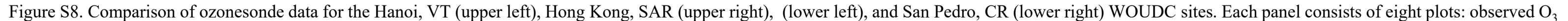

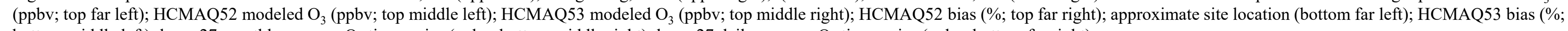
bottom middle left); layer 27 monthly average $\mathrm{O}_{3}$ time series (ppbv; bottom middle right); layer 27 daily average $\mathrm{O}_{3}$ time series (ppbv; bottom far right). 


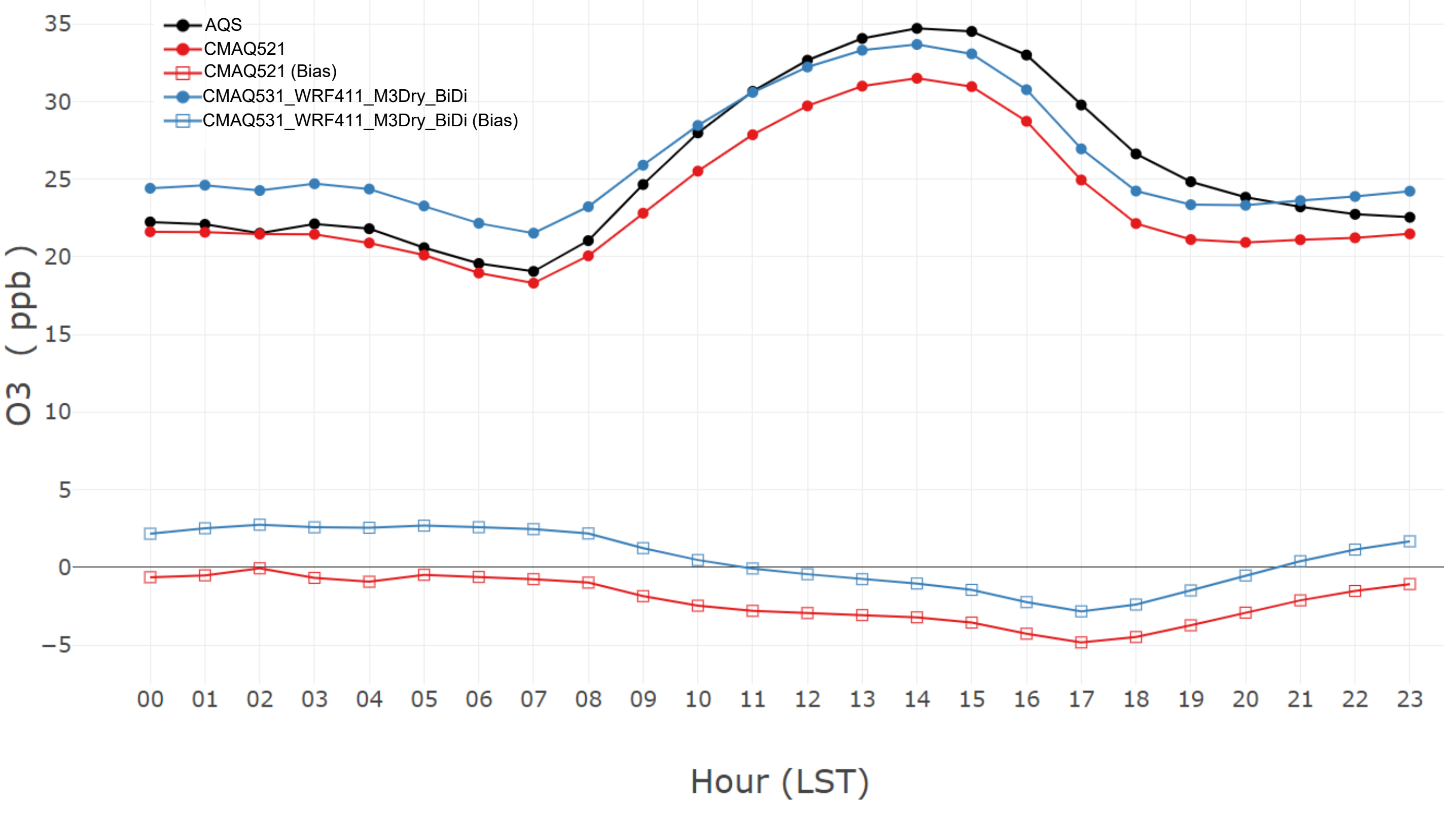

Figure S9. Time series of hourly average $\mathrm{O}_{3}$ (ppbv; filled circles) and bias (open squares; ppbv) for all AQS sites for winter for the CMAQ521 (red) and CMAQ531_WRF411_M3Dry_BiDi (blue) simulations. 


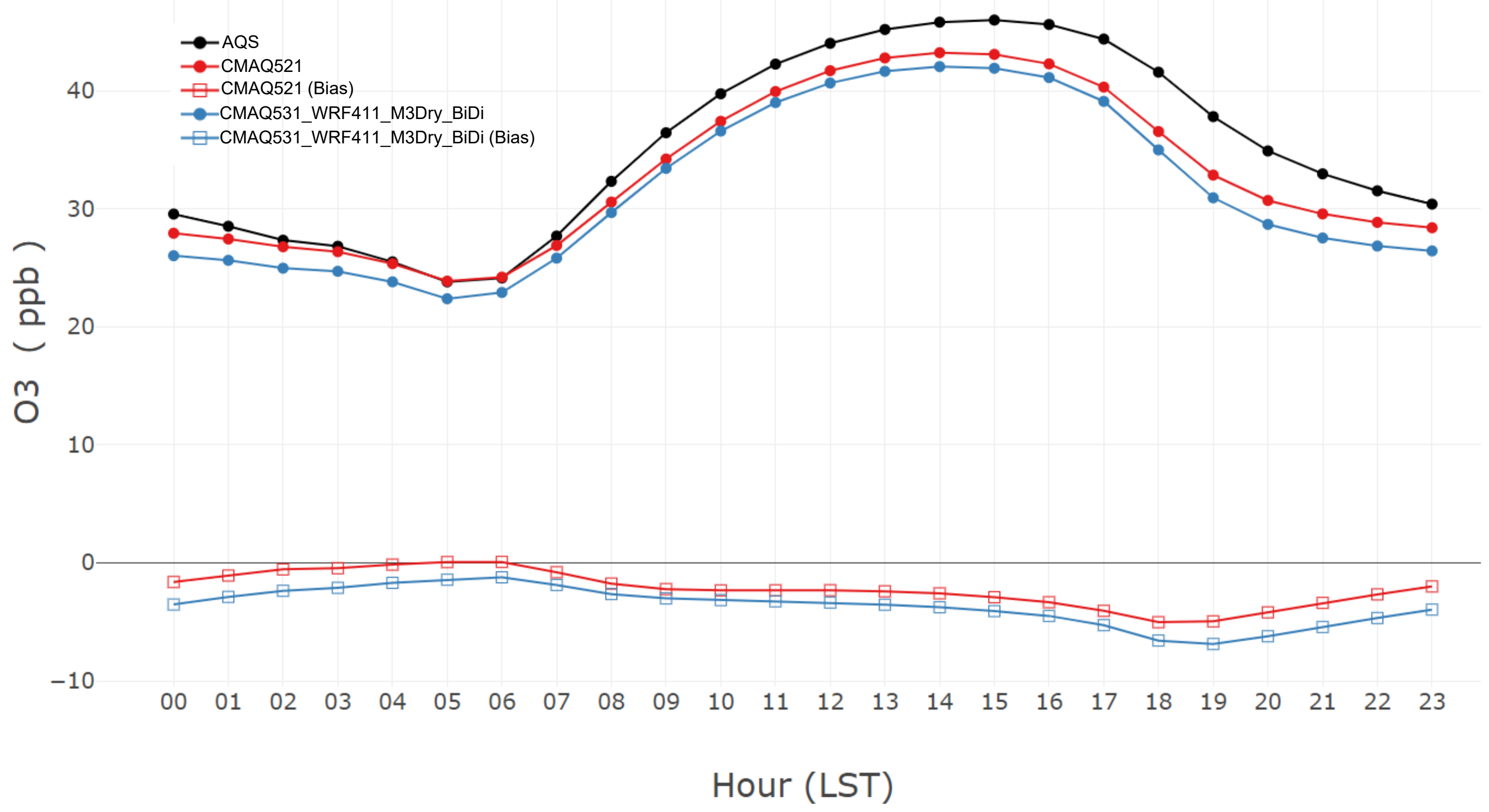

Figure S10. Time series of hourly average $\mathrm{O}_{3}$ (ppbv; filled circles) and bias (open squares; ppbv) for all AQS sites for spring for the CMAQ521 (red) and CMAQ531_WRF411_M3Dry_BiDi (blue) simulations. 


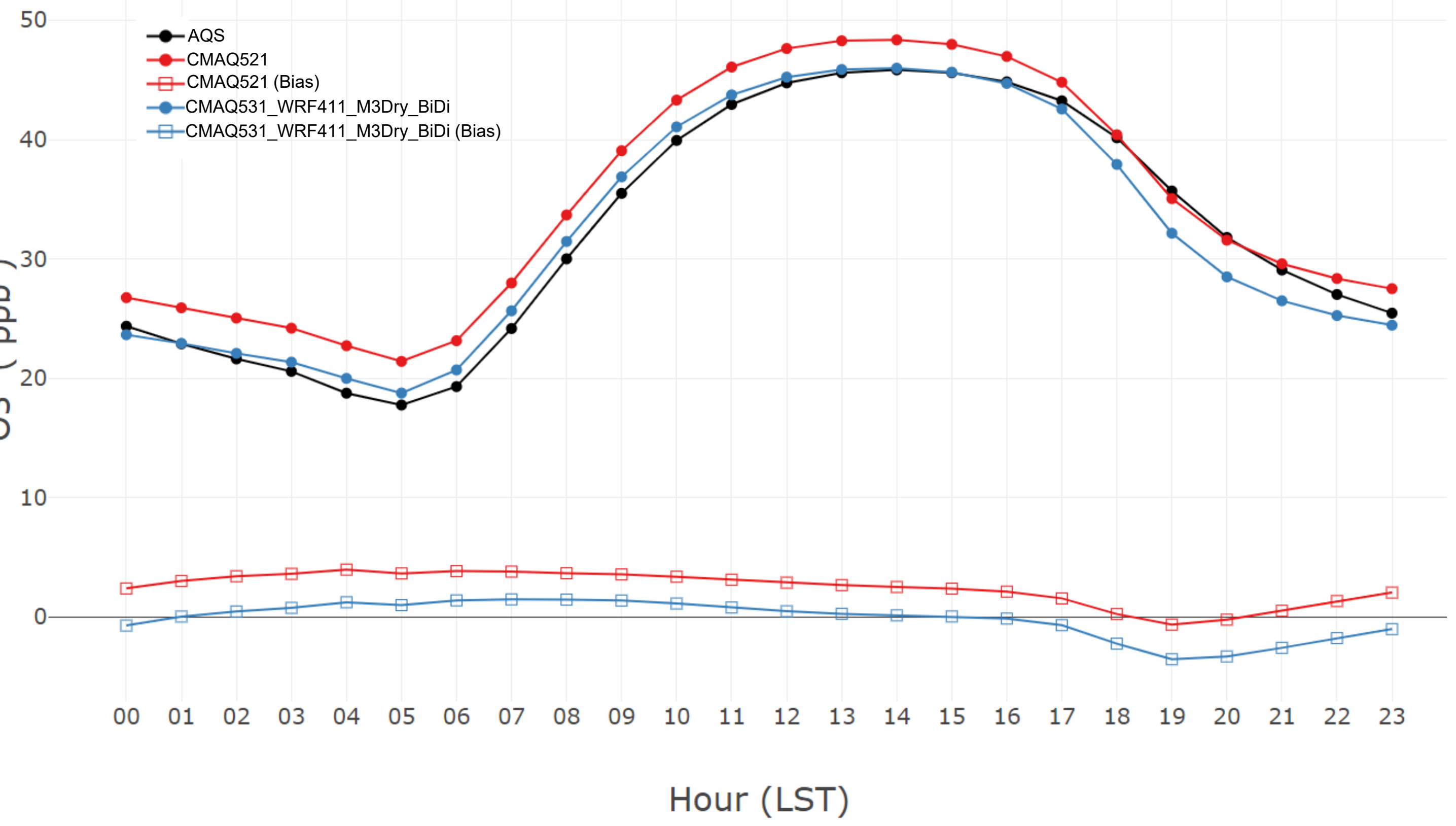

Figure S11. Time series of hourly average $\mathrm{O}_{3}$ (ppbv; filled circles) and bias (open squares; ppbv) for all AQS sites for summer for the CMAQ521 (red) and CMAQ531_WRF411_M3Dry_BiDi (blue) simulations. 


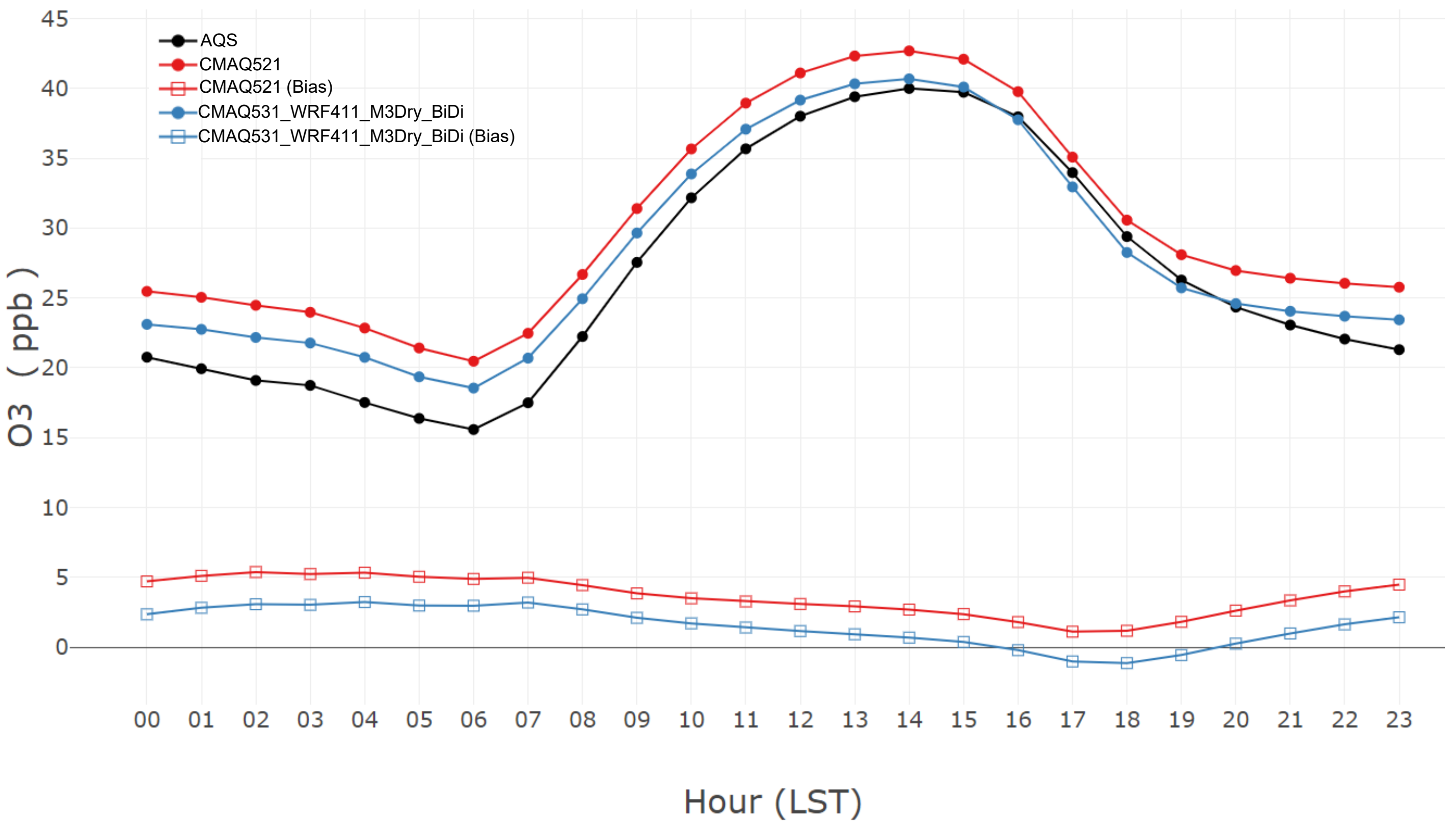

Figure $\mathrm{S} 12$. Time series of hourly average $\mathrm{O}_{3}$ (ppbv; filled circles) and bias (open squares; ppbv) for all AQS sites for fall for the CMAQ521 (red) and CMAQ531_WRF411_M3Dry_BiDi (blue) simulations. 

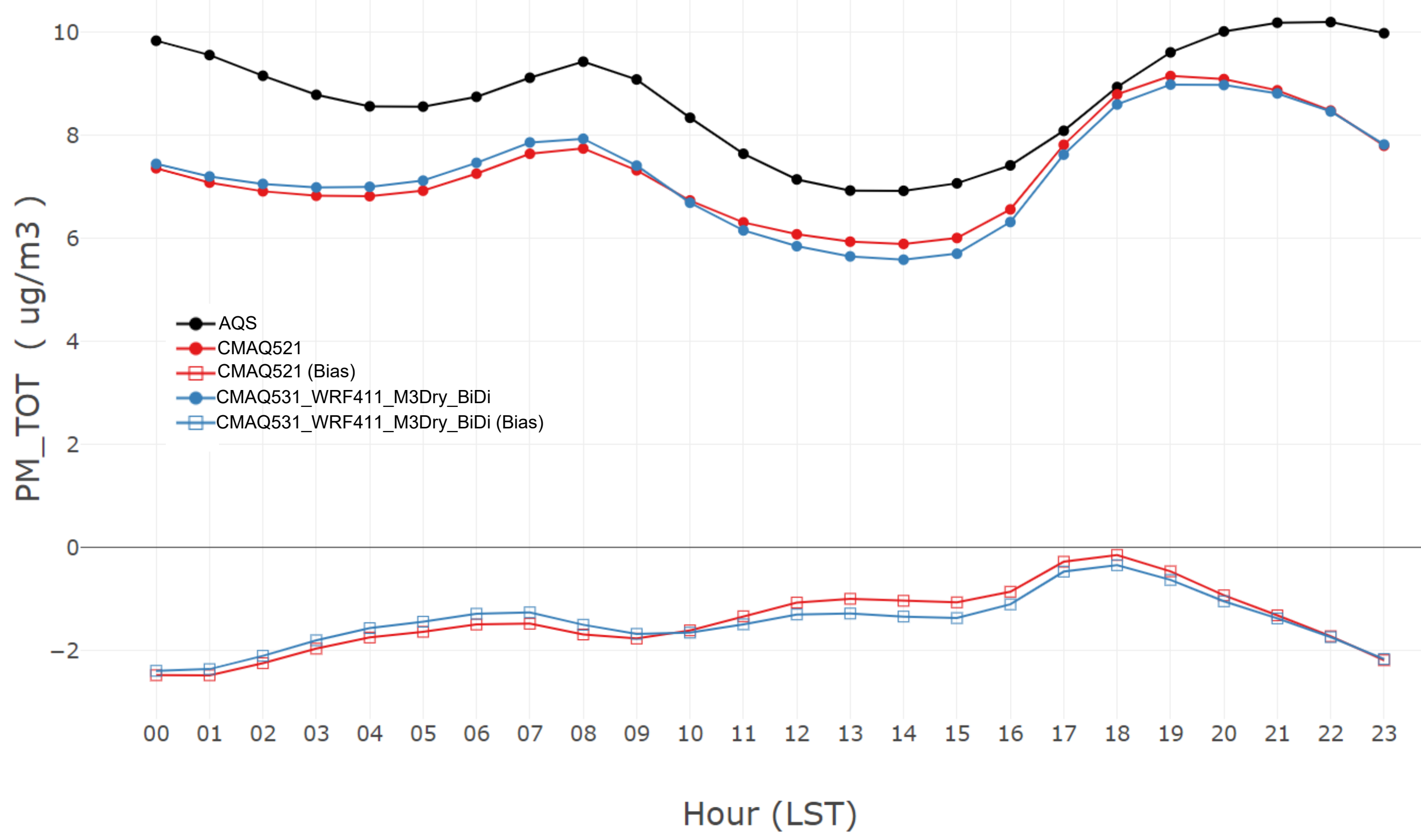

Figure S13. Time series of hourly average $\mathrm{PM}_{2.5}\left(\mu \mathrm{g} \mathrm{m}^{-3}\right.$; filled circles) and bias $\left(\mu \mathrm{g} \mathrm{m}^{-3}\right.$; open squares) for all AQS sites for winter for the CMAQ521 (red) and CMAQ531_WRF411_M3Dry_BiDi (blue) simulations. 


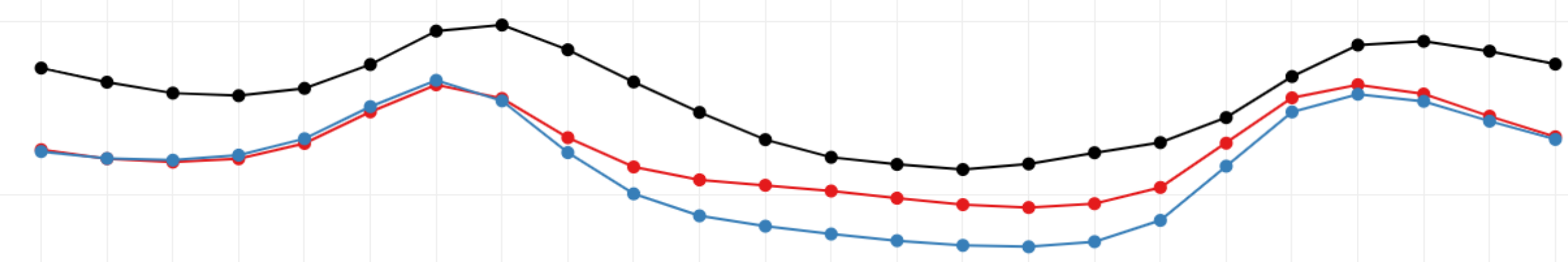

$m$

m

हิ

ত্

$\smile \longrightarrow$ CMAQ521

$\vdash \quad \square$ CMAQ521 (Bias)

只 $\rightarrow$-CMAQ531_WRF411_M3Dry_BiDi

—CMAQ531_WRF411_M3Dry_BiDi (Bias)

$\sum^{12}$

$$
0
$$

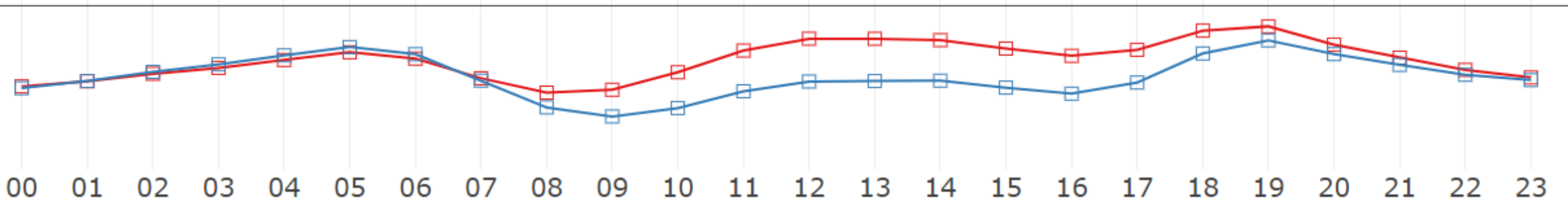

\section{Hour (LST)}

Figure S14. Time series of hourly average $\mathrm{PM}_{2.5}\left(\mu \mathrm{g} \mathrm{m}^{-3}\right.$; filled circles) and bias ( $\mu \mathrm{g} \mathrm{m}^{-3}$; open squares) for all AQS sites for spring for the CMAQ521 (red) and CMAQ531_WRF411_M3Dry_BiDi (blue) simulations. 


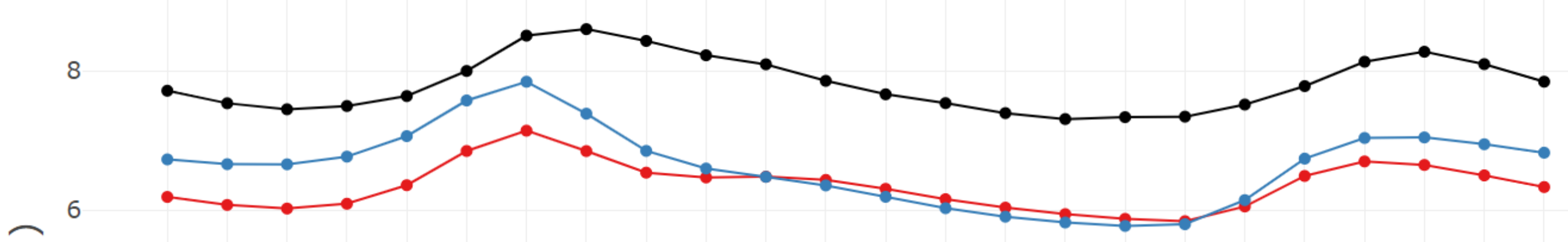

$m$

듬

ㅇำ 4
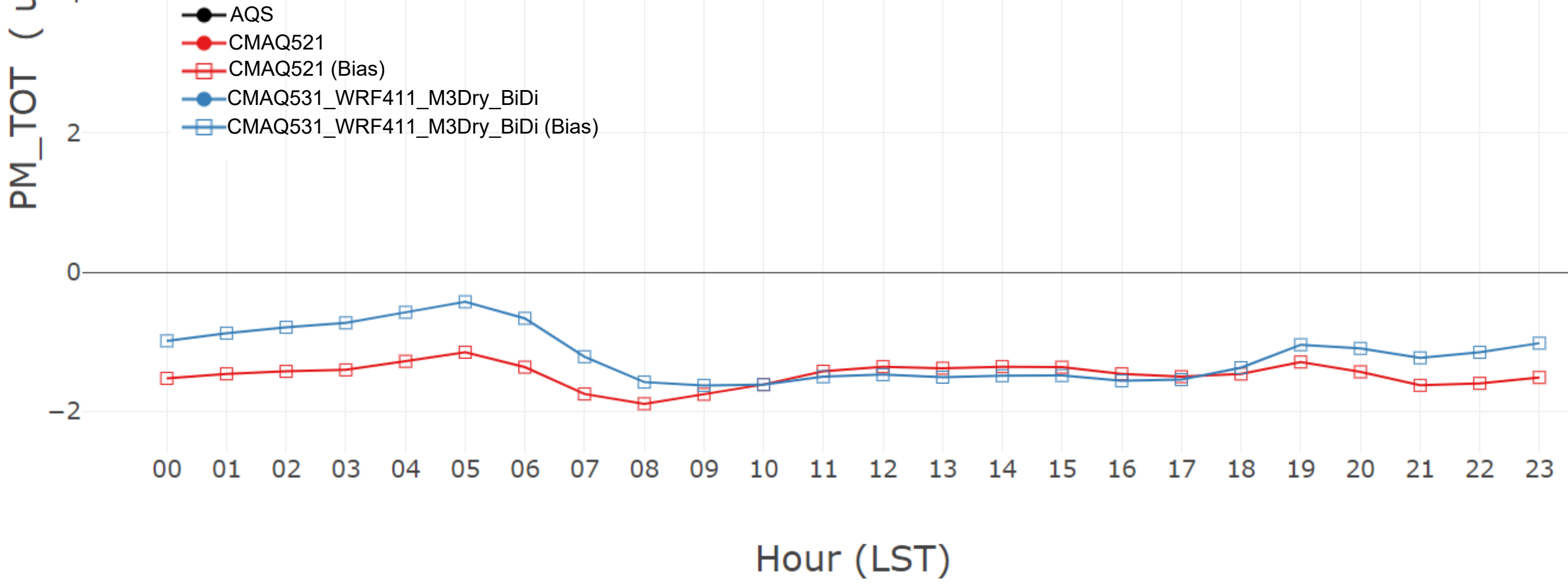

Figure S15. Time series of hourly average $\mathrm{PM}_{2.5}\left(\mu \mathrm{g} \mathrm{m}^{-3}\right.$; filled circles) and bias ( $\mu \mathrm{g} \mathrm{m}^{-3}$; open squares) for all AQS sites for summer for the CMAQ521 (red) and CMAQ531_WRF411_M3Dry_BiDi (blue) simulations. 


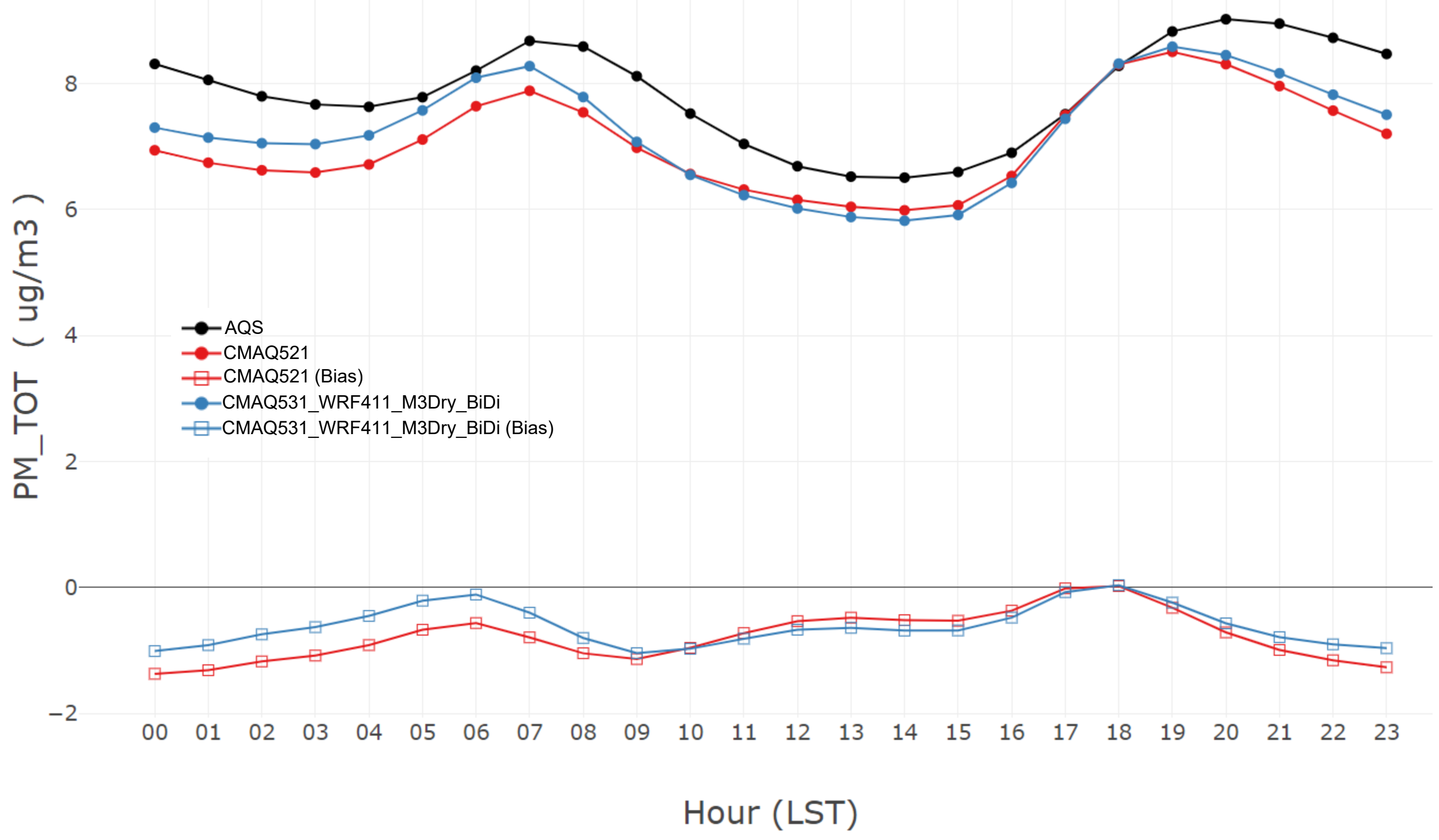

Figure S16. Time series of hourly average $\mathrm{PM}_{2.5}\left(\mu \mathrm{g} \mathrm{m}^{-3}\right.$; filled circles) and bias ( $\mu \mathrm{g} \mathrm{m}^{-3}$; open squares) for all AQS sites for fall for the CMAQ521 (red) and CMAQ531_WRF411_M3Dry_BiDi (blue) simulations. 


\section{NMB}

Ohio Valley Upper Midwest

Southeast South NRockiesPlains

Southwest West Northwest.

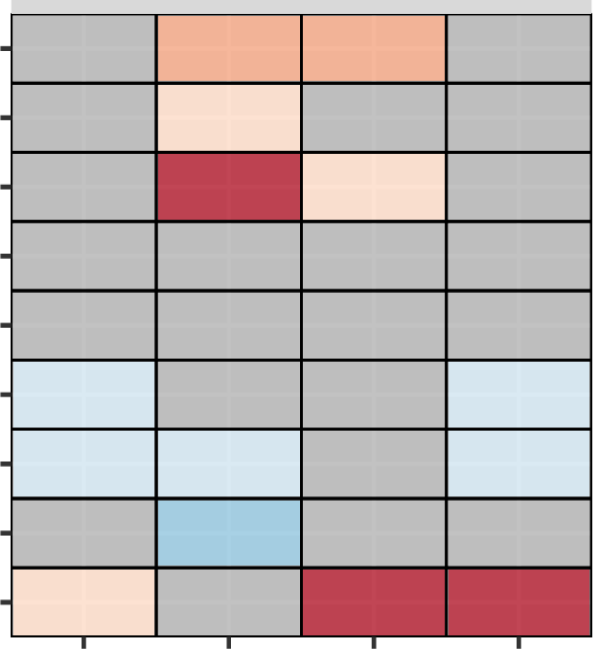

Fall Wtr Spr Sum

RMSE

Northeast

Ohio Valley Upper Midwest

Southeast South NRockiesPlains

Southwest West Northwest

\begin{tabular}{|l|l|l|l|}
\multicolumn{5}{|c}{ RMSE } \\
\hline & & & \\
\hline & & & \\
\hline & & & \\
\hline & & & \\
\hline & & & \\
\hline & & & \\
\hline & & & \\
\hline & & & \\
\hline & & & \\
\hline
\end{tabular}

Fall Wtr Spr Sum
$\%$

$>80$

60 to 80

40 to 60

20 to 40

-20 to 20

-40 to -20

-60 to -40

-80 to -60

-100 to -80

$\mathrm{ug} / \mathrm{m} 3$

$\square$ to 4.5 3.5 to 4 3 to 3.5 2.5 to 3 2 to 2.5 NRockin 1.5 to 2 1 to 1.5 0.5 to 1 0 to 0.5

\section{MB}
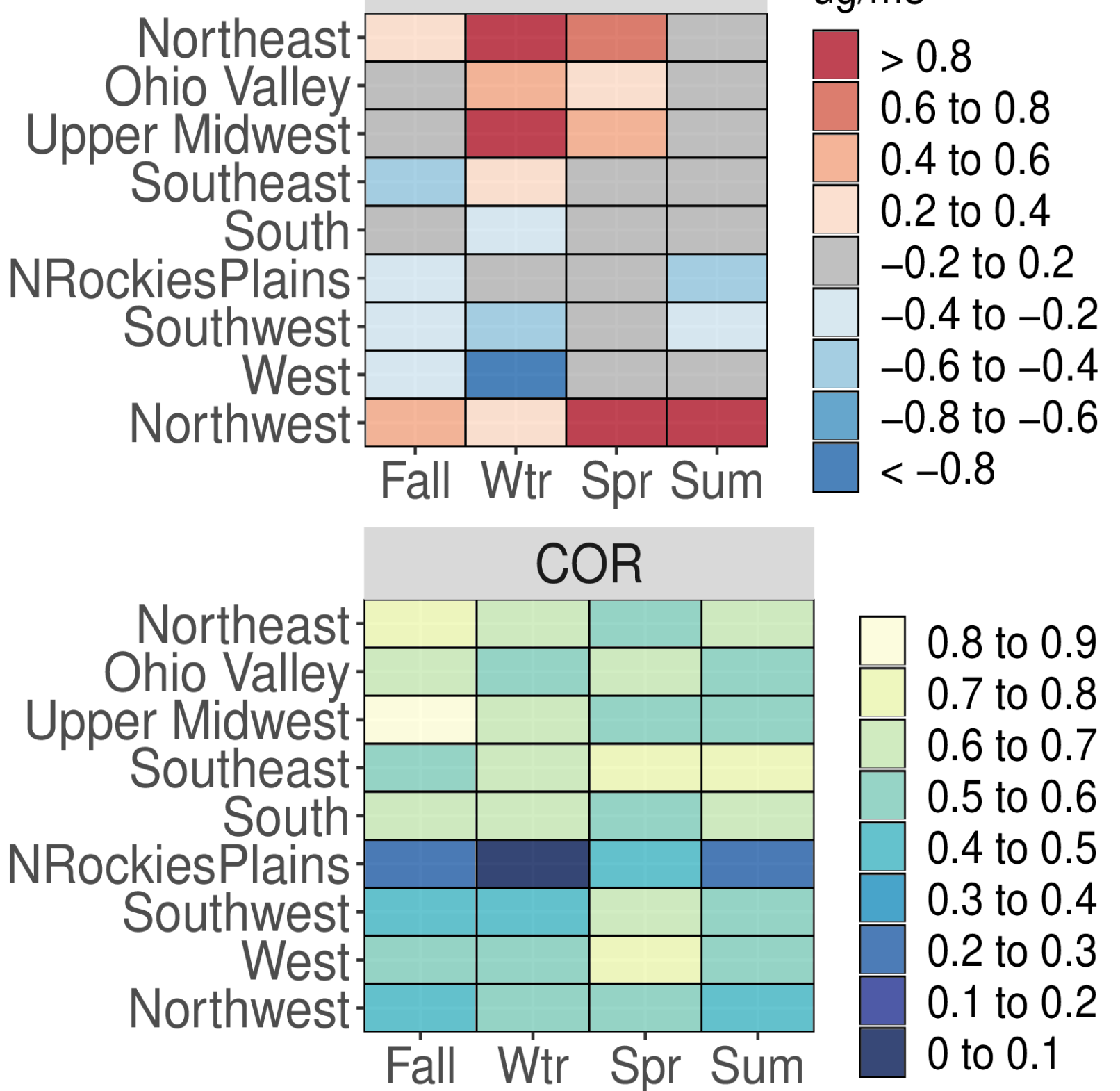

Figure S17. Categorical NMB (\%), MB $\left(\mu \mathrm{g} \mathrm{m}^{-3}\right)$, RMSE $\left(\mu \mathrm{g} \mathrm{m}^{-3}\right)$, and Pearson correlation values for OC for all CSN sites based on season and NOAA climate region for the CMAQ521 simulation. 


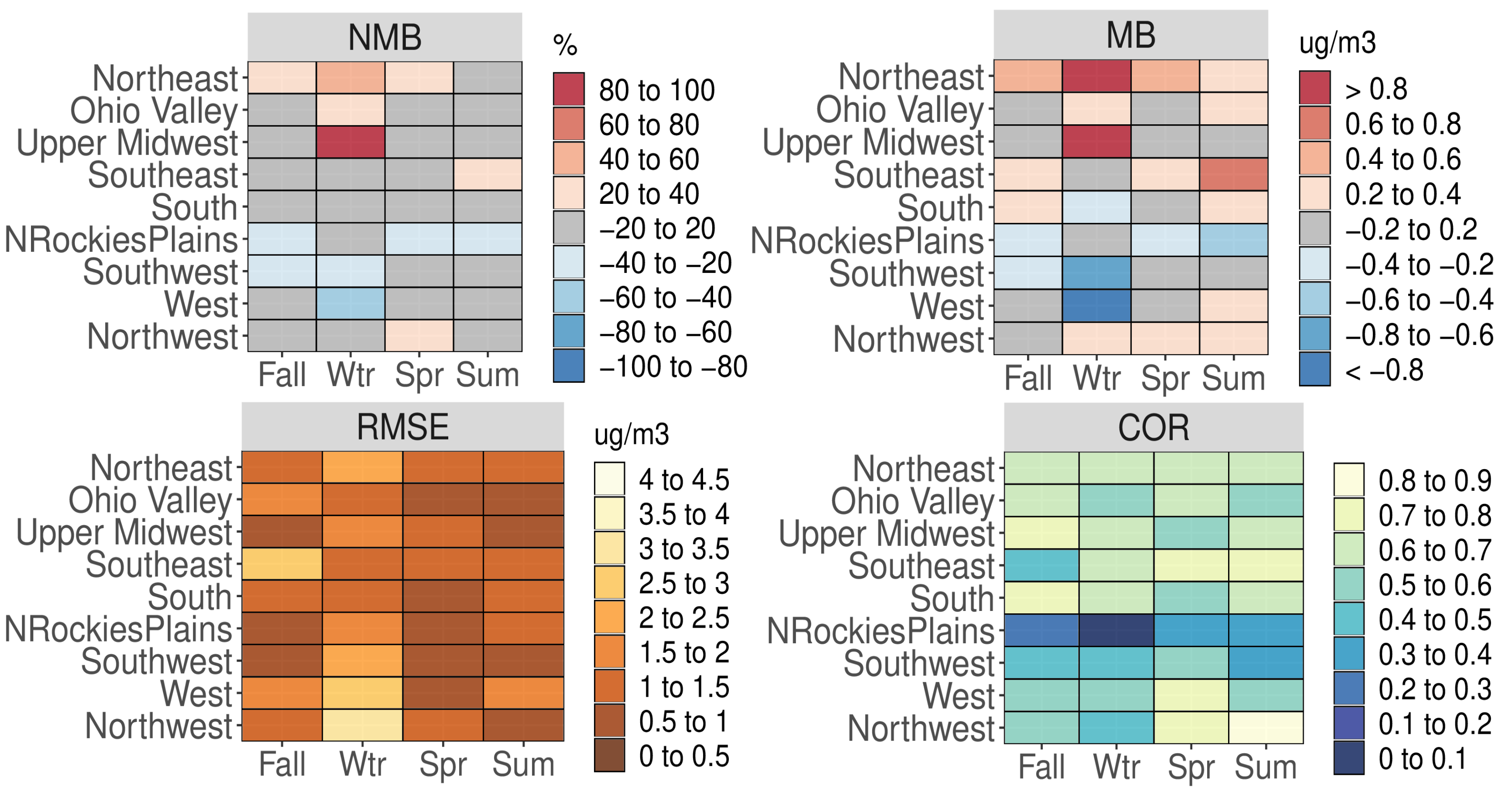

Figure S18. Categorical NMB (\%), MB $\left(\mu \mathrm{g} \mathrm{m}^{-3}\right)$, RMSE $\left(\mu \mathrm{g} \mathrm{m}^{-3}\right)$, and Pearson correlation values for OC for all CSN sites based on season and NOAA climate region for the CMAQ531_WRF411_M3Dry_BiDi simulation. 


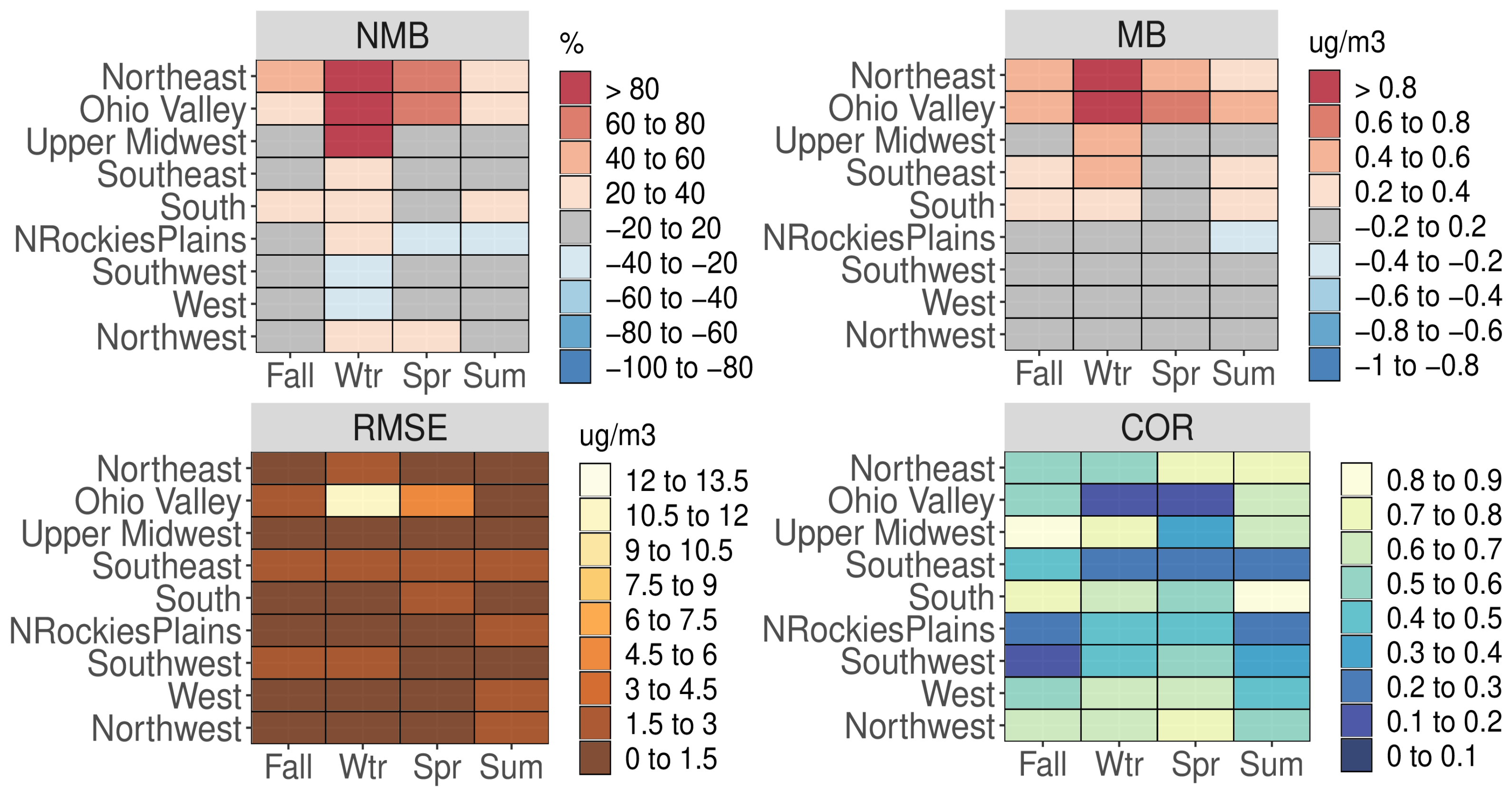

Figure S20. Categorical NMB (\%), MB $\left(\mu \mathrm{g} \mathrm{m}^{-3}\right)$, RMSE $\left(\mu \mathrm{g} \mathrm{m}^{-3}\right)$, and Pearson correlation values for OC for all IMPROVE sites based on season and NOAA climate region for the CMAQ531_WRF411_M3Dry_BiDi simulation. 


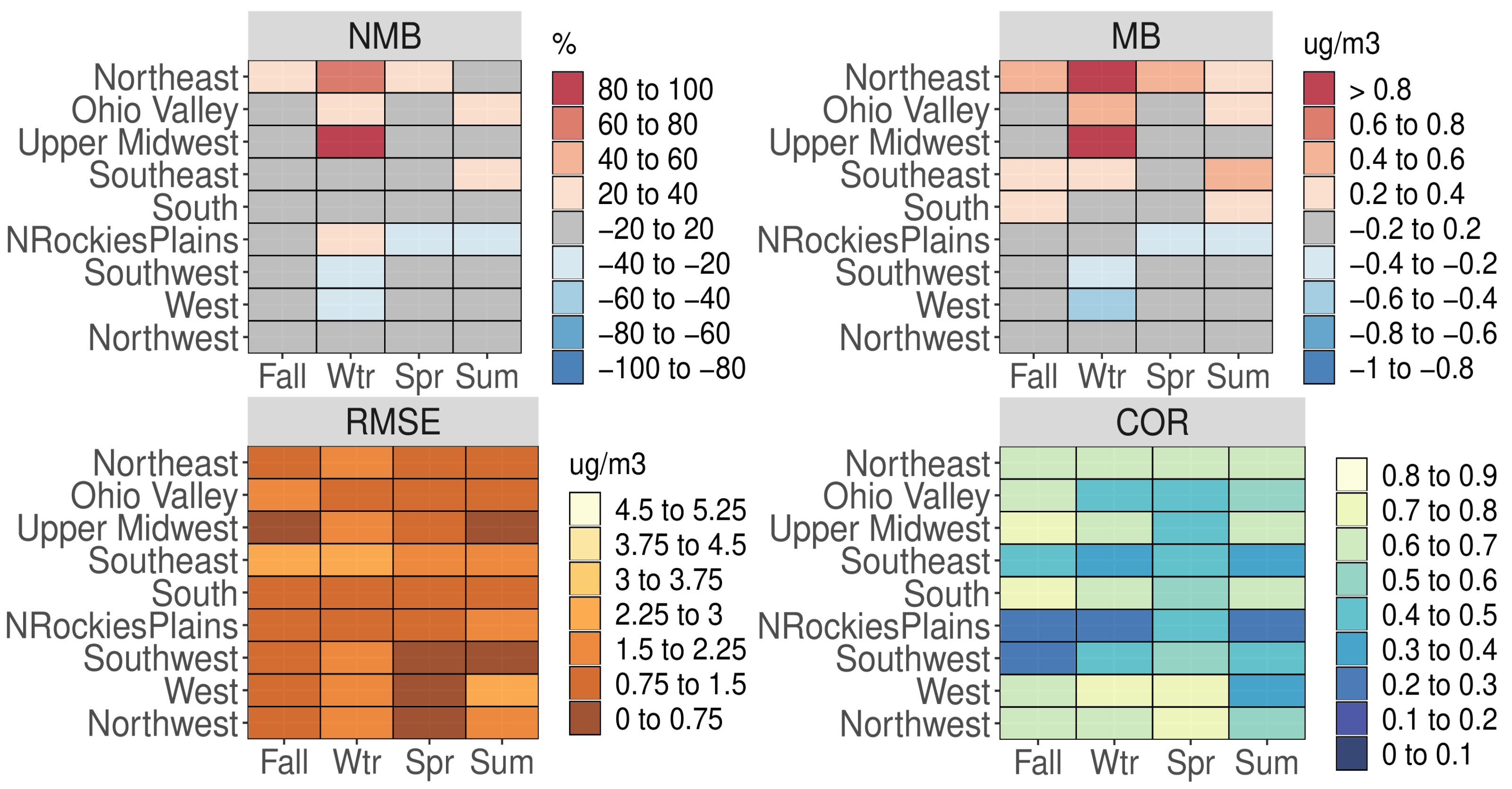

Figure S22. Categorical NMB (\%), MB $\left(\mu \mathrm{g} \mathrm{m}^{-3}\right)$, RMSE $\left(\mu \mathrm{g} \mathrm{m}^{-3}\right)$, and Pearson correlation values for OC for all AQS sites based on season and NOAA climate region for the CMAQ531_WRF411_M3Dry_BiDi simulation. 


\section{NMB}

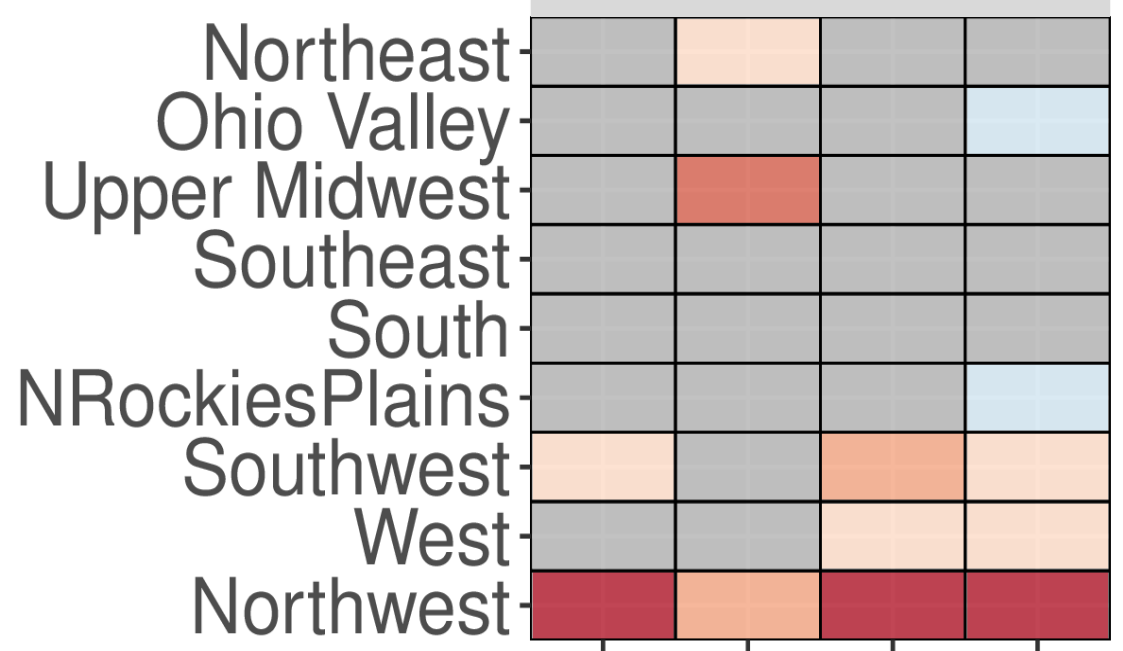

Fall Wtr Spr Sum
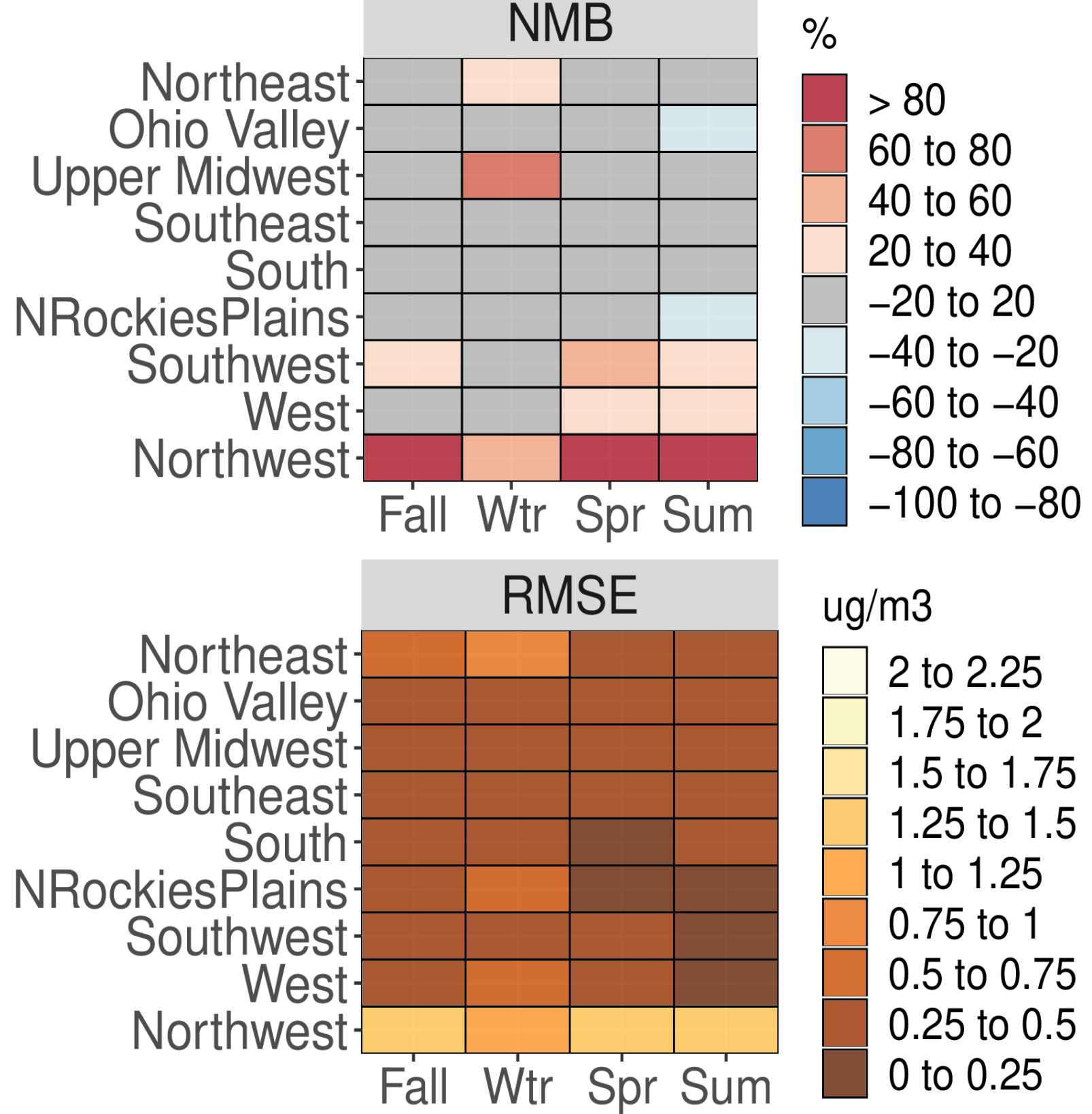

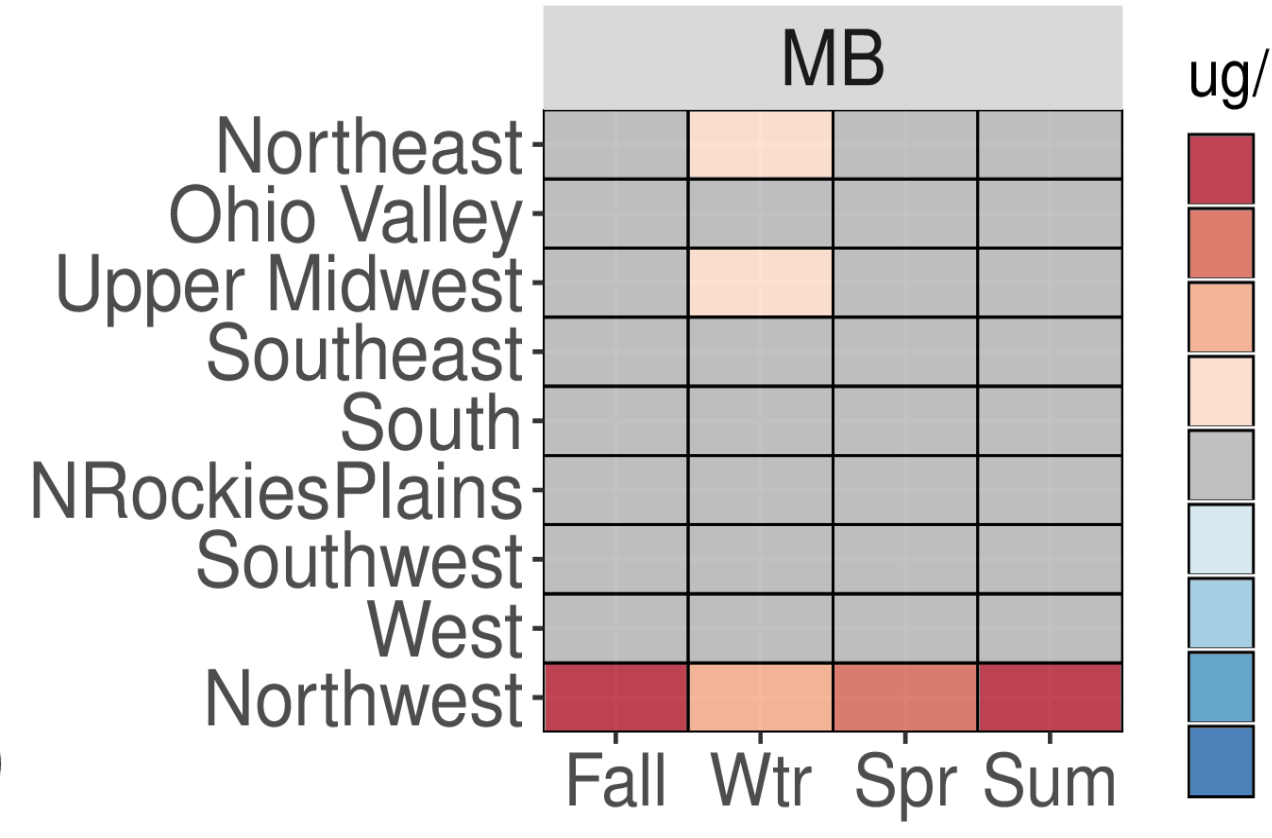

$\mathrm{ug} / \mathrm{m} 3$

0.8 to 1 0.6 to 0.8

0.4 to 0.6 0.2 to 0.4 -0.2 to 0.2 -0.4 to -0.2 -0.6 to -0.4 -0.8 to -0.6 -1 to -0.8

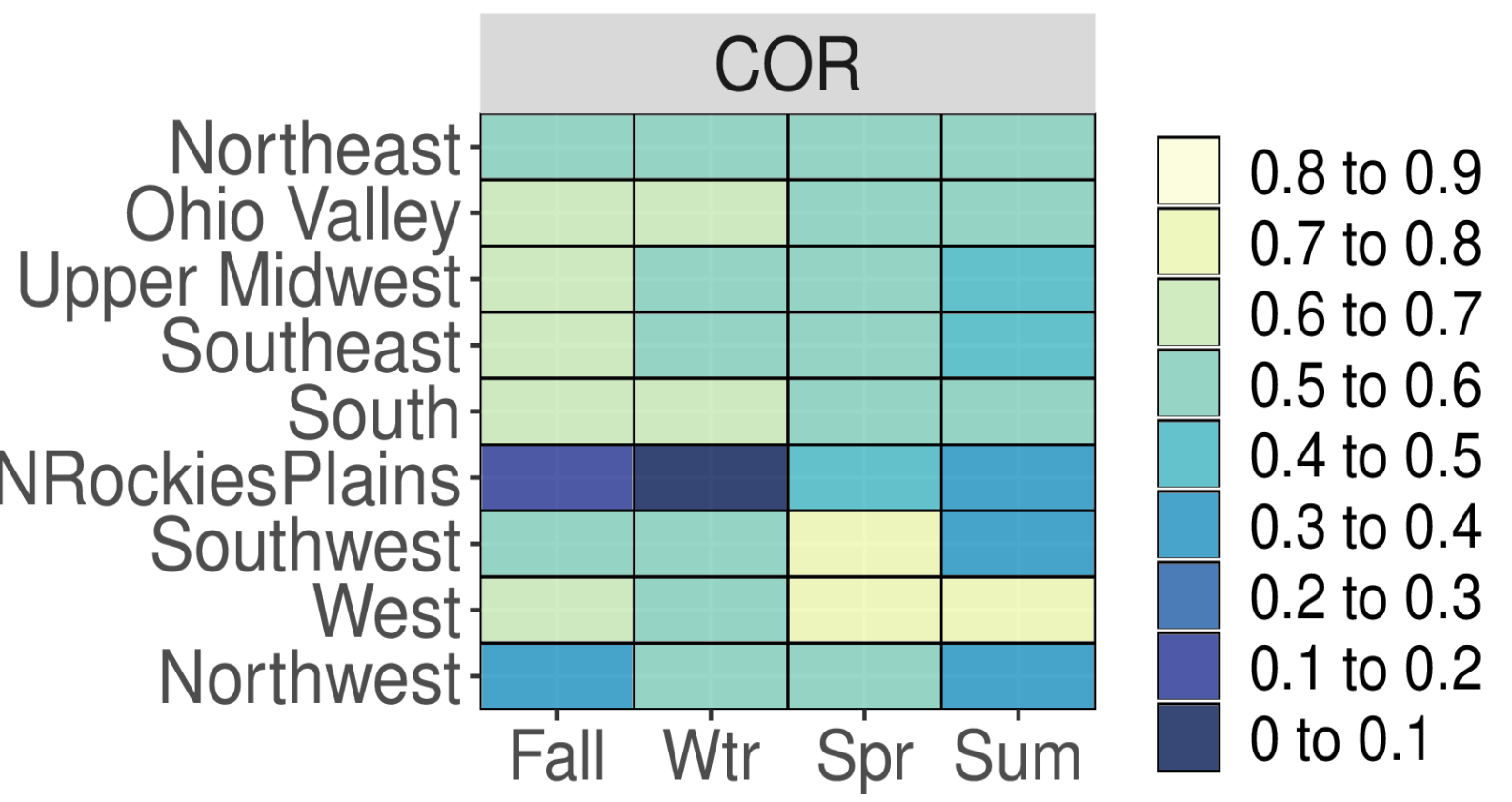

Figure S23. Categorical NMB (\%), MB $\left(\mu \mathrm{g} \mathrm{m}^{-3}\right)$, RMSE $\left(\mu \mathrm{g} \mathrm{m}^{-3}\right)$, and Pearson correlation values for EC for all CSN sites based on season and NOAA climate region for the CMAQ521 simulation. 


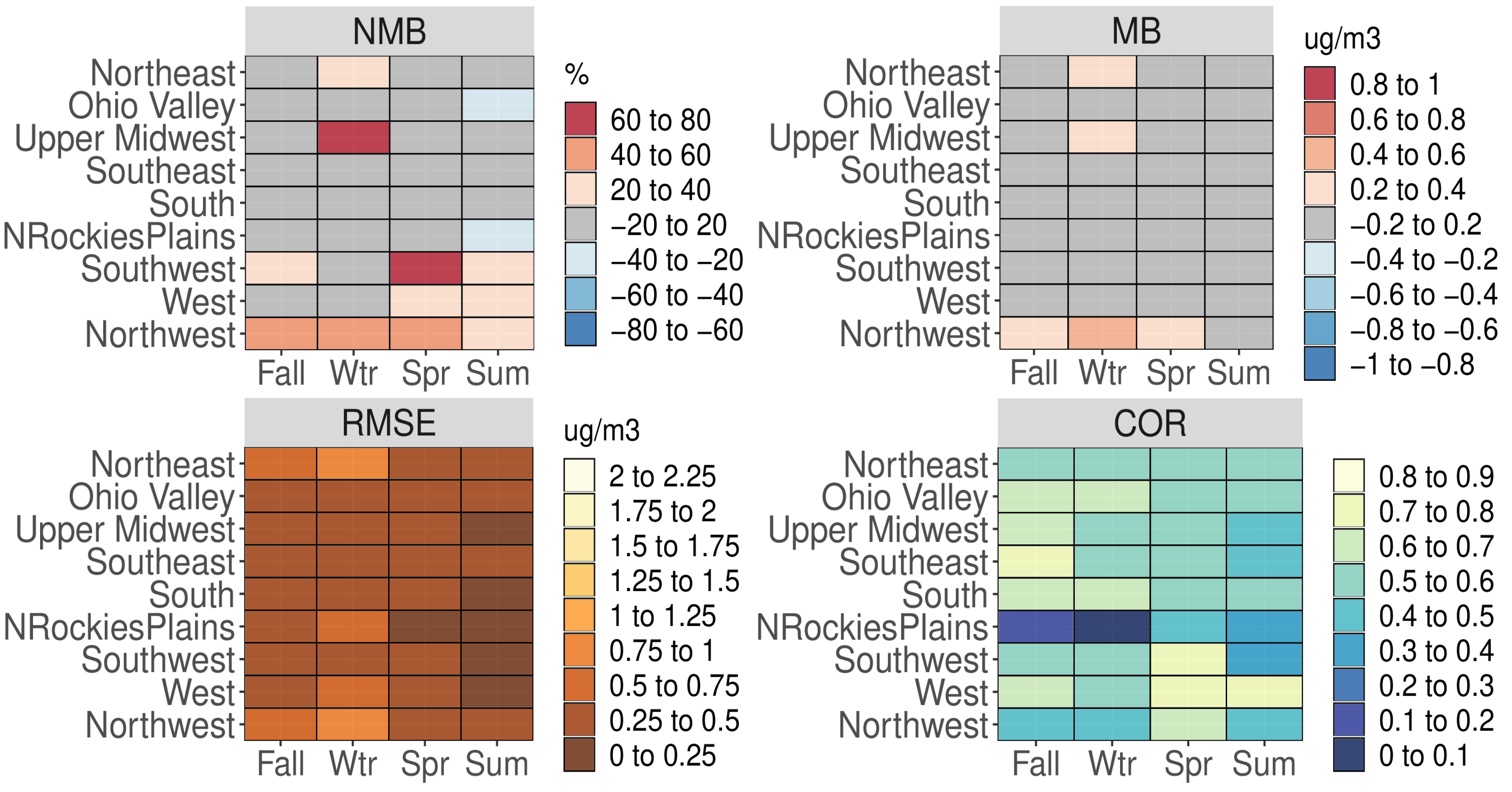

Figure S24. Categorical NMB (\%), MB ( $\left.\mu \mathrm{g} \mathrm{m}^{-3}\right)$, RMSE $\left(\mu \mathrm{g} \mathrm{m}^{-3}\right)$, and Pearson correlation values for EC for all CSN sites based on season and NOAA climate region for the CMAQ531_WRF411_M3Dry_BiDi simulation. 
NMB

Ohio Valley

Upper Midwest

Southeast

South

NRockiesPlains

Southwest

West

Northwest

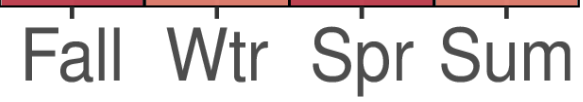

Fall Wtr Spr Sum

\section{RMSE}

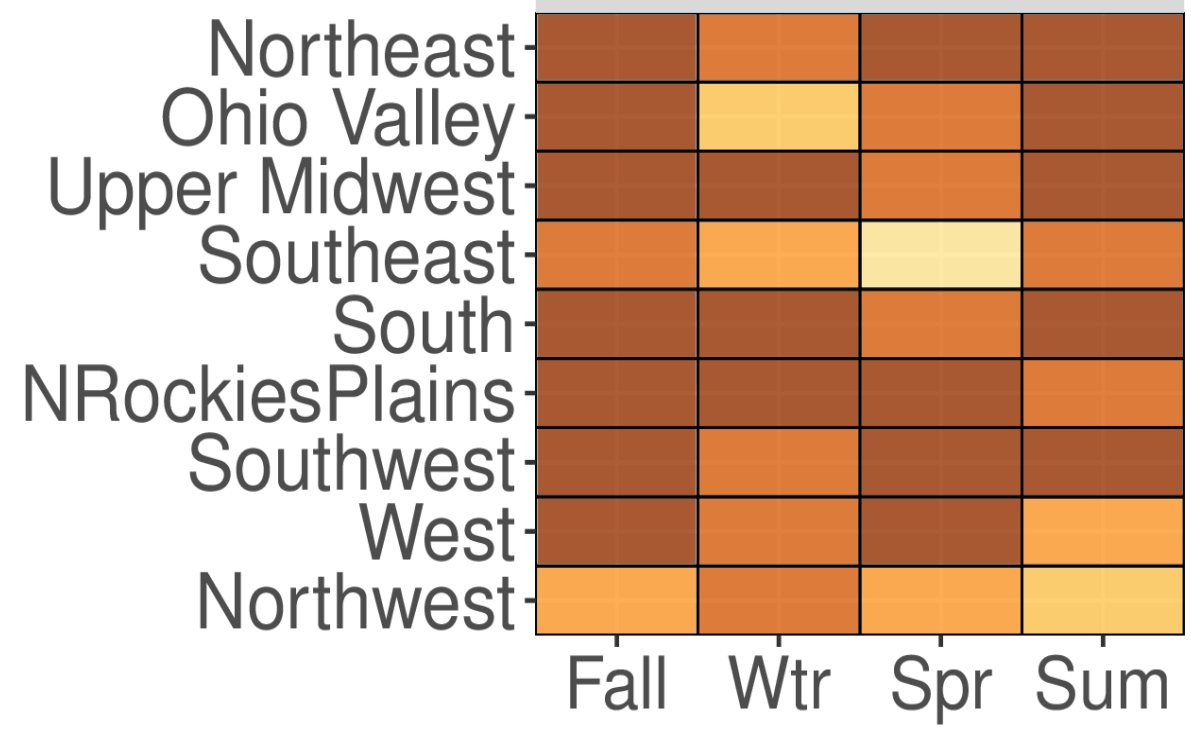

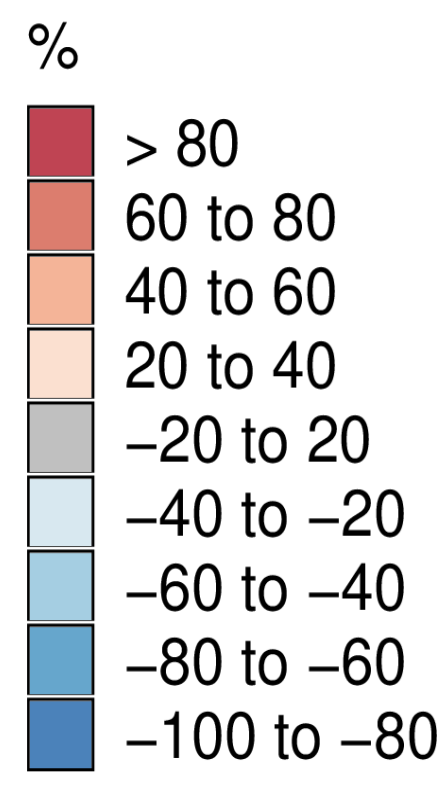

MB

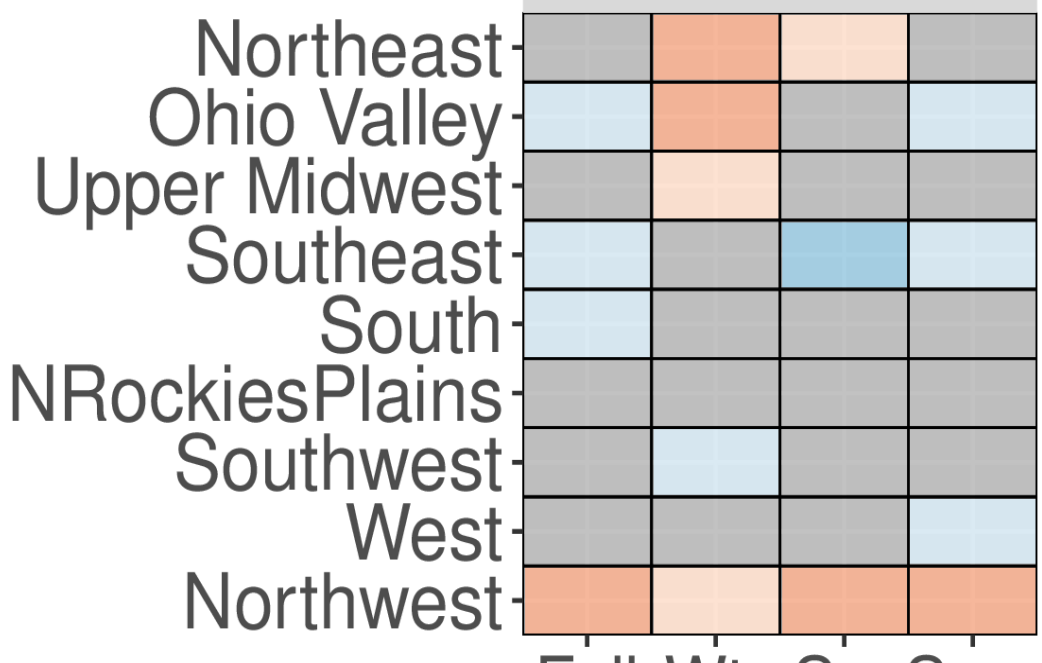

Fall Wtr SprSum $\mathrm{ug} / \mathrm{m} 3$

0.16 to 0.2

0.12 to 0.16

0.08 to 0.12

0.04 to 0.08

-0.04 to 0.04

-0.08 to -0.04

-0.12 to -0.08

-0.16 to -0.12

-0.2 to -0.16

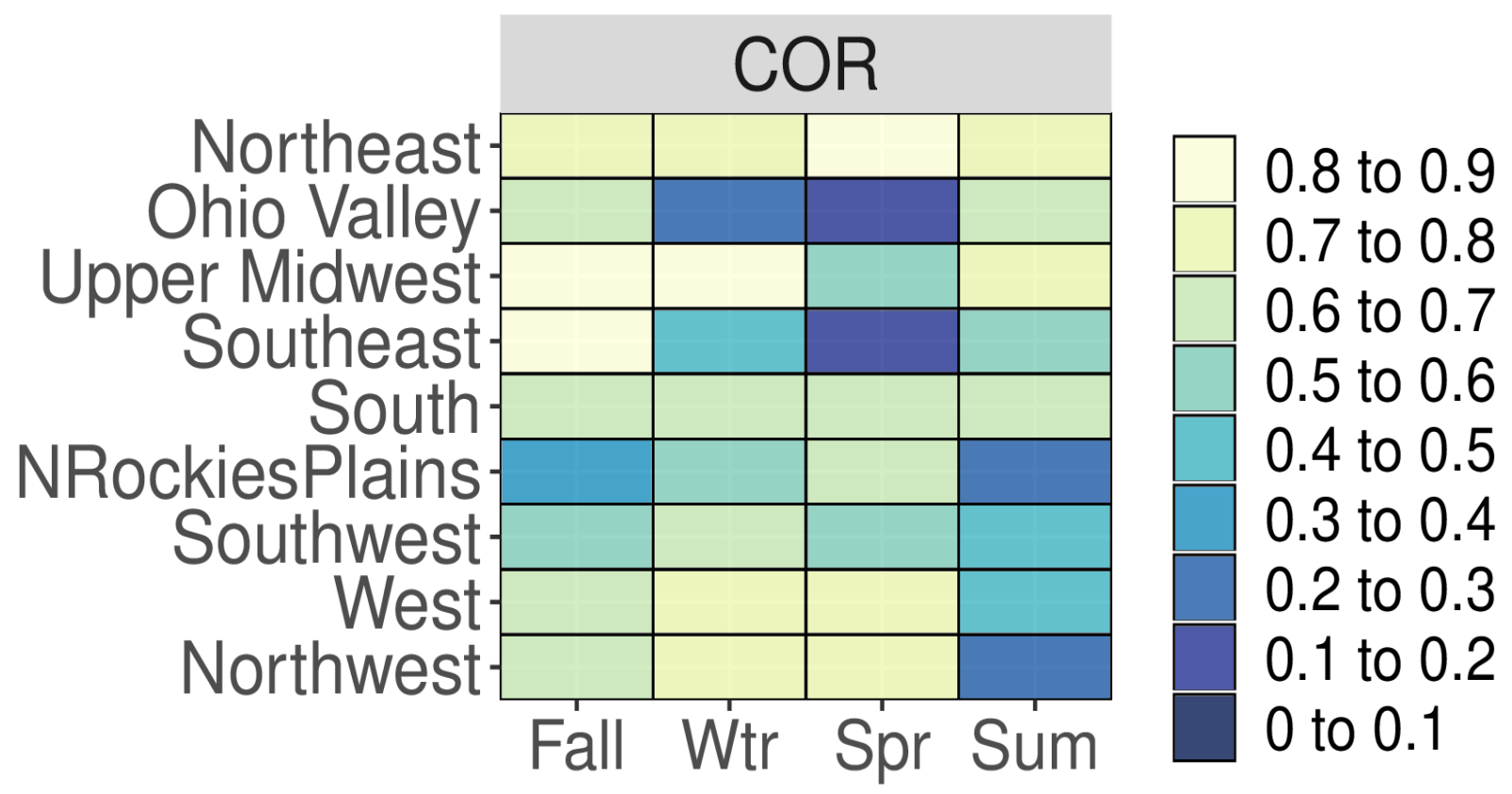

Ohio Valley

Southwest

Northwest
South

Fall Wtr Spr Sum

Figure S25. Categorical NMB (\%), MB $\left(\mu \mathrm{g} \mathrm{m}^{-3}\right)$, RMSE $\left(\mu \mathrm{g} \mathrm{m}^{-3}\right)$, and Pearson correlation values for EC for all IMPROVE sites based on season and NOAA climate region for the CMAQ521 simulation.

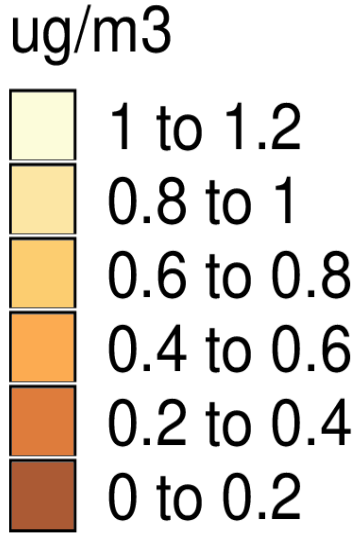

\begin{tabular}{|l|l|}
1 & to 1.2 \\
& 0.8 to 1 \\
\hline & 0.6 to 0.8 \\
0.4 to 0.6 \\
0.2 to 0.4 \\
0 to 0.2
\end{tabular} 


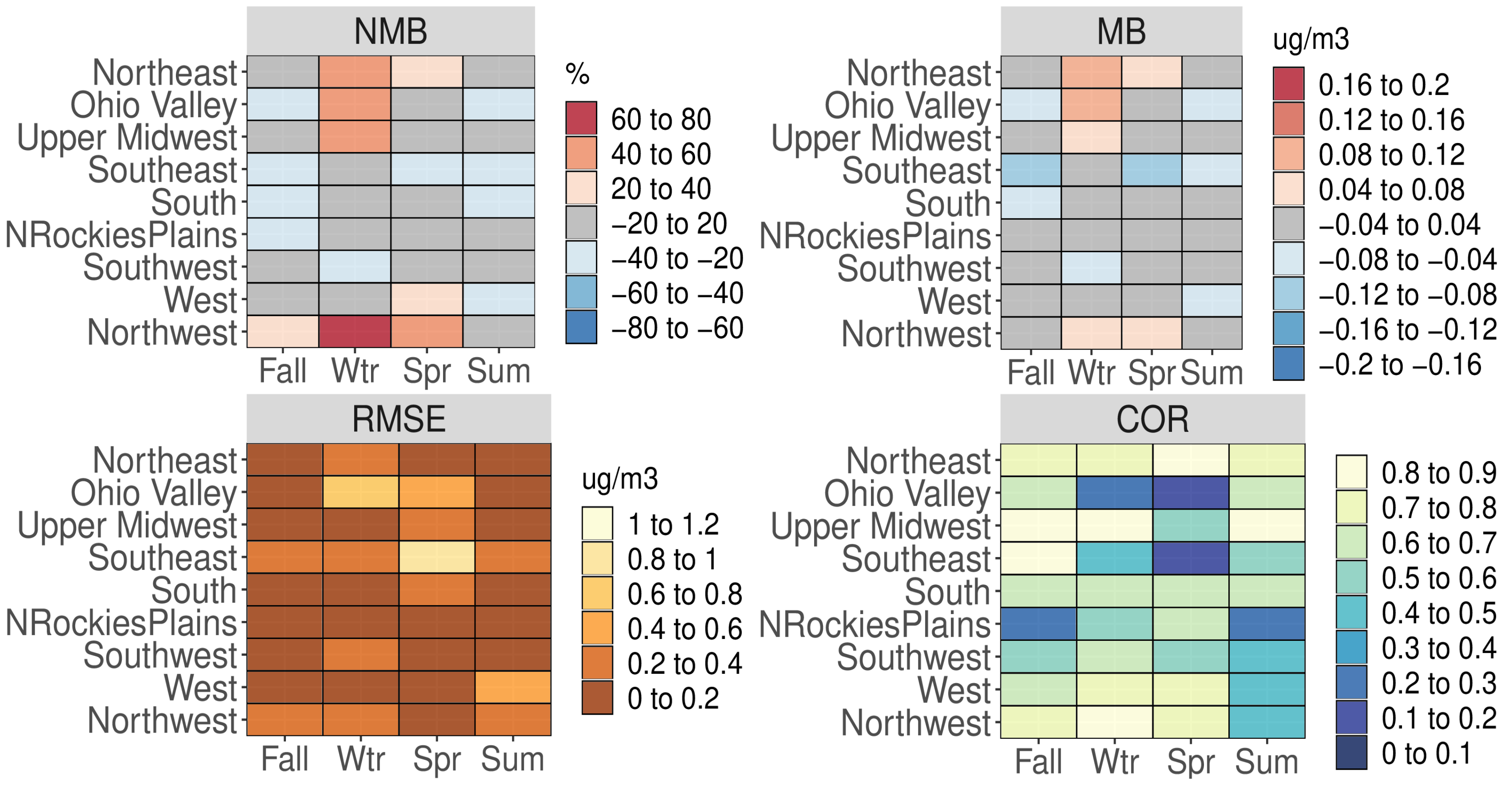

Figure S26. Categorical NMB (\%), MB $\left(\mu \mathrm{g} \mathrm{m}^{-3}\right)$, RMSE $\left(\mu \mathrm{g} \mathrm{m}^{-3}\right)$, and Pearson correlation values for EC for all IMPROVE sites based on season and NOAA climate region for the CMAQ531_WRF411_M3Dry_BiDi simulation. 


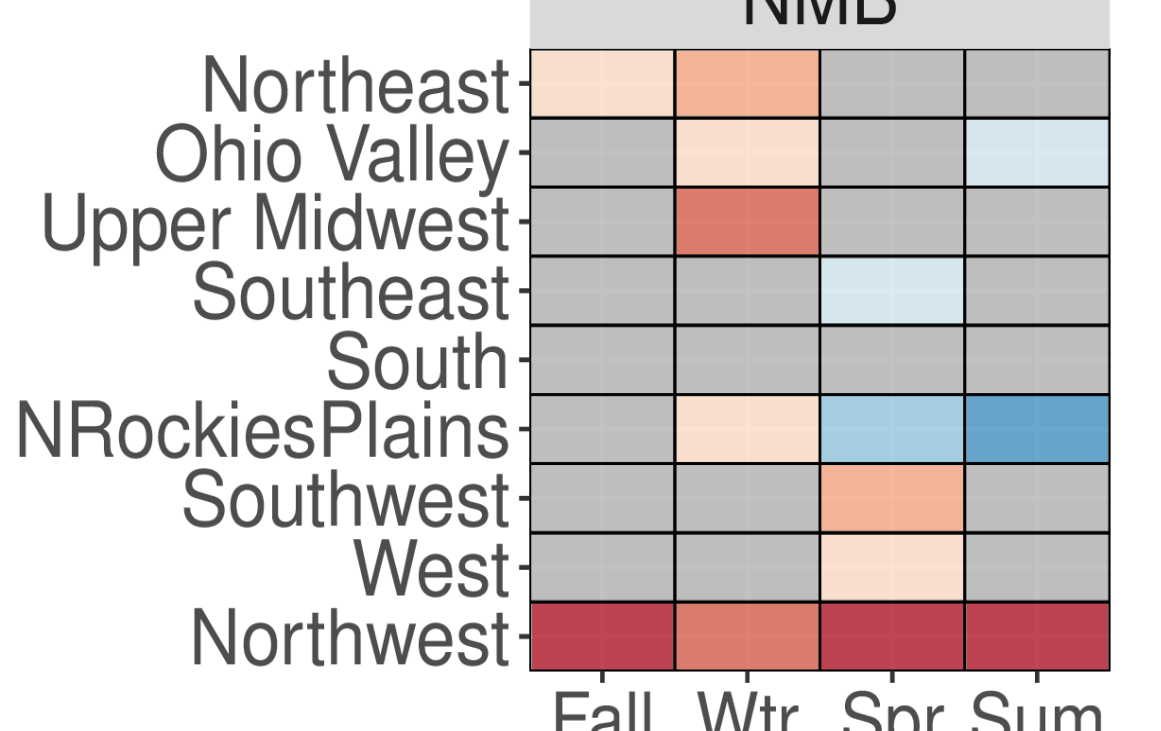

Fall Wtr Spr Sum

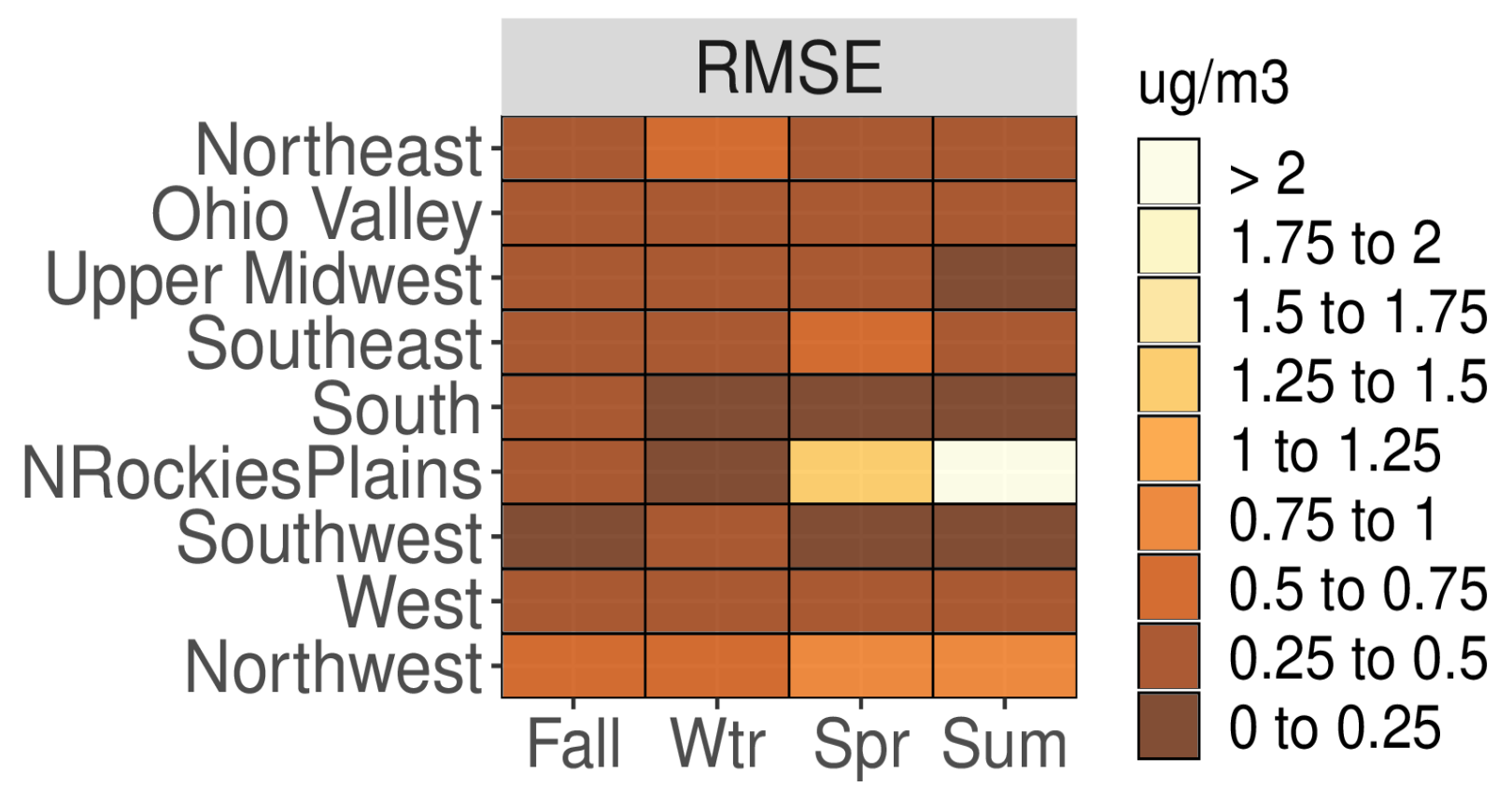

$\square>80$

60 to 80

40 to 60

20 to 40

-20 to 20

-40 to -20

-60 to -40

-80 to -60

-100 to -80
$\%$

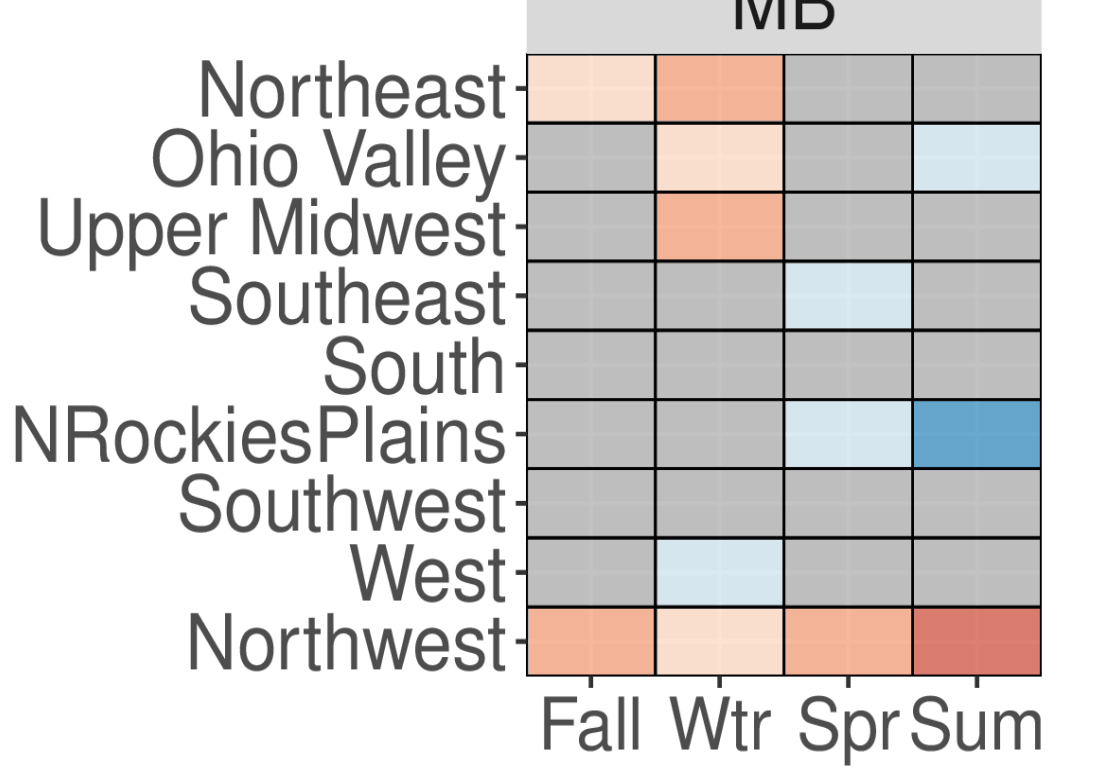

$\mathrm{ug} / \mathrm{m} 3$

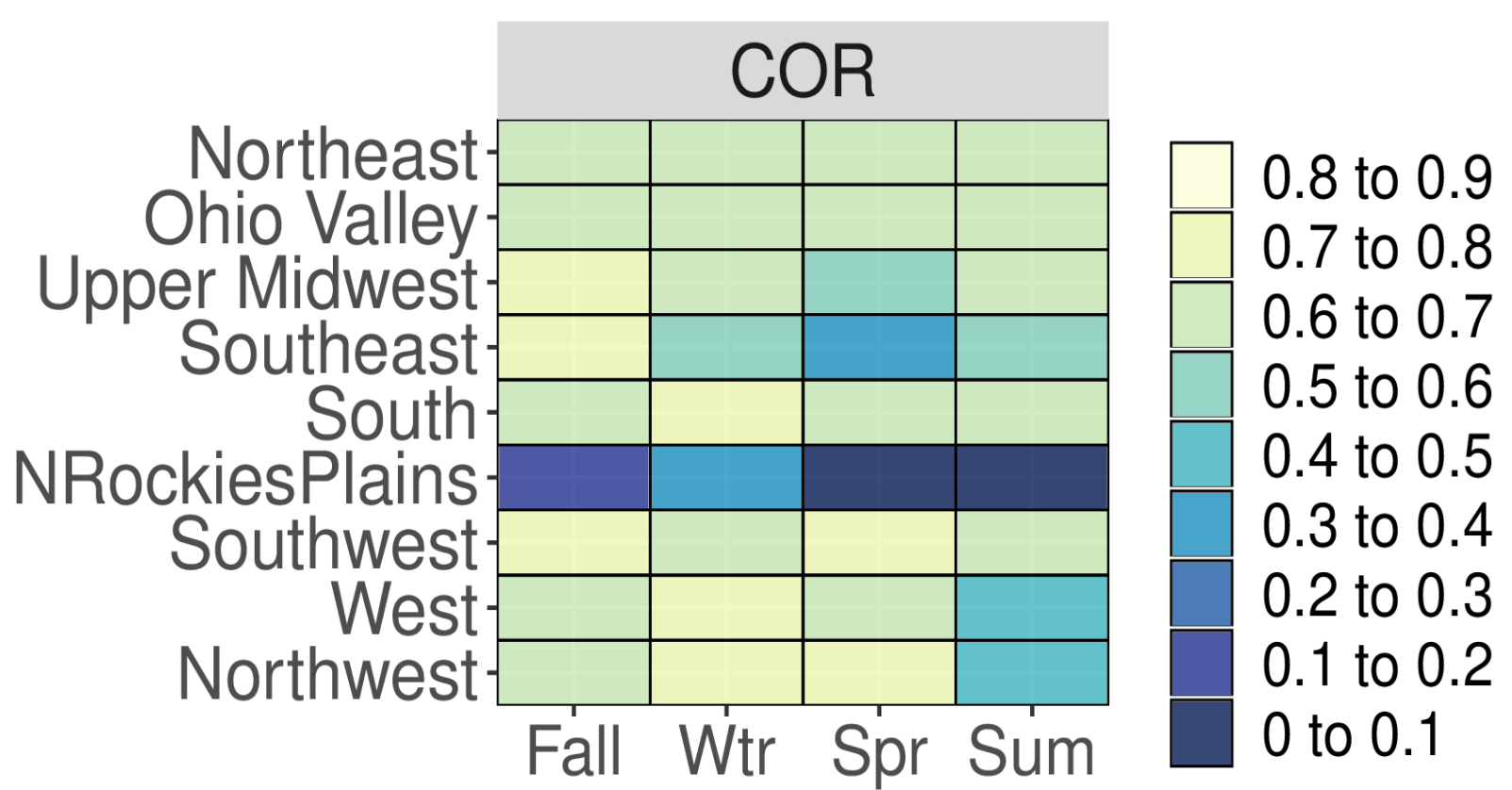

Figure S27. Categorical NMB (\%), MB $\left(\mu \mathrm{g} \mathrm{m}^{-3}\right)$, RMSE $\left(\mu \mathrm{g} \mathrm{m}^{-3}\right)$, and Pearson correlation values for EC for all AQS sites based on season and NOAA climate region for the CMAQ521 simulation. 
NMB

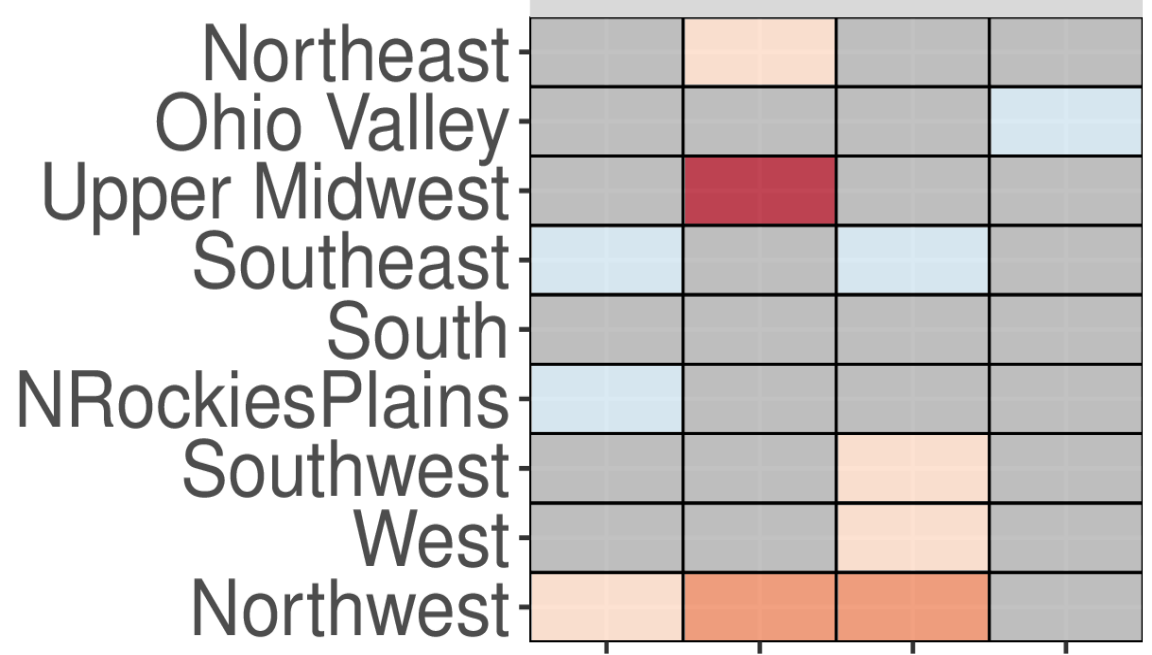

Fáll Wtr Spr Sum

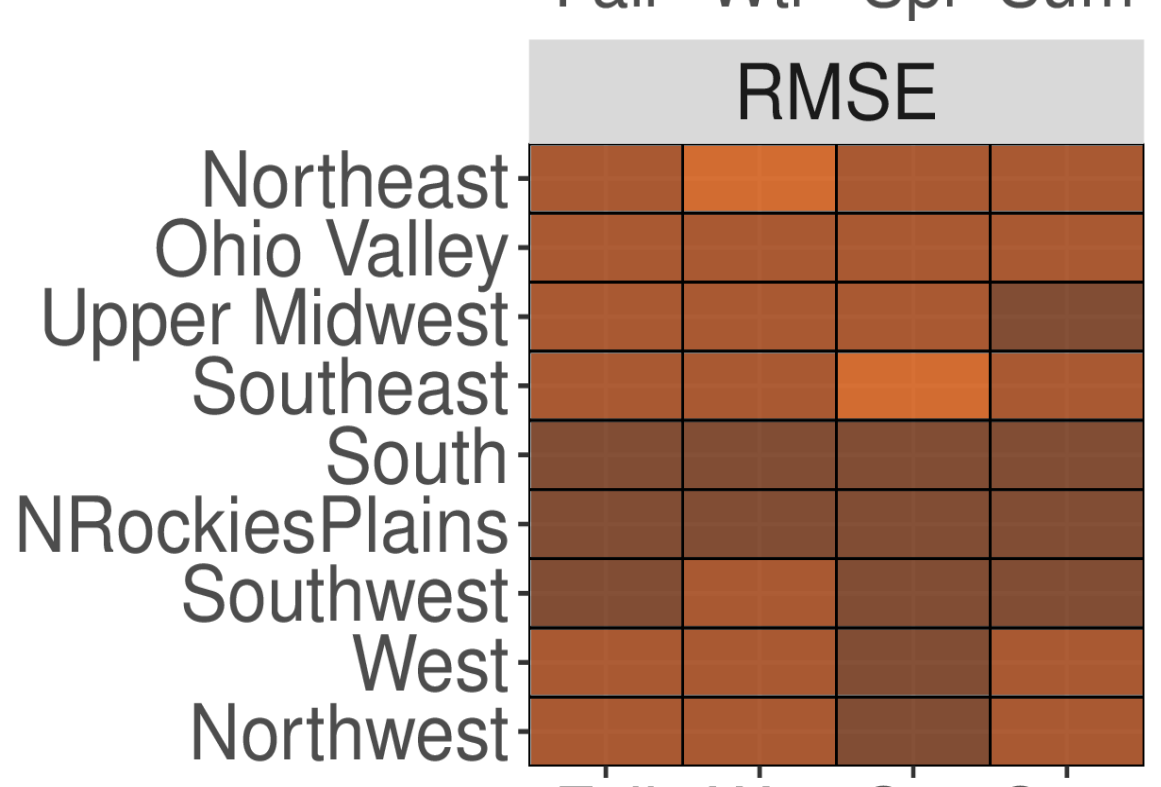

Fall Wtr Spr Sum

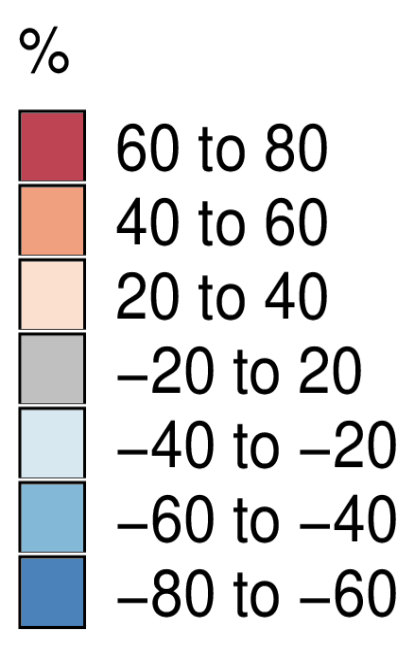

Northeast
Ohio Valley
Upper Midwest
Southeast
South
NRockiesPlains
Southwest
West
Northwest

$\mathrm{ug} / \mathrm{m} 3$

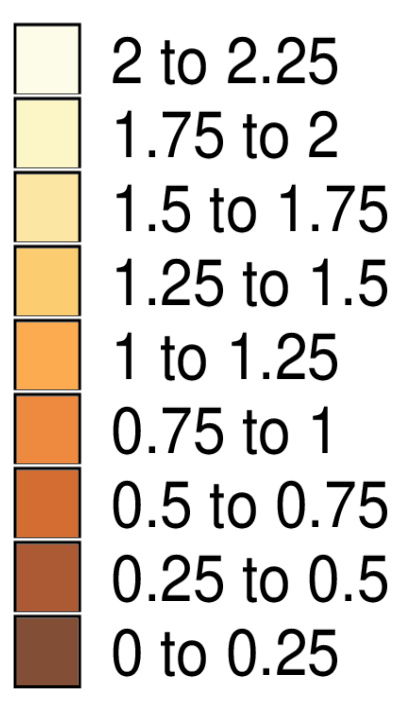

MB

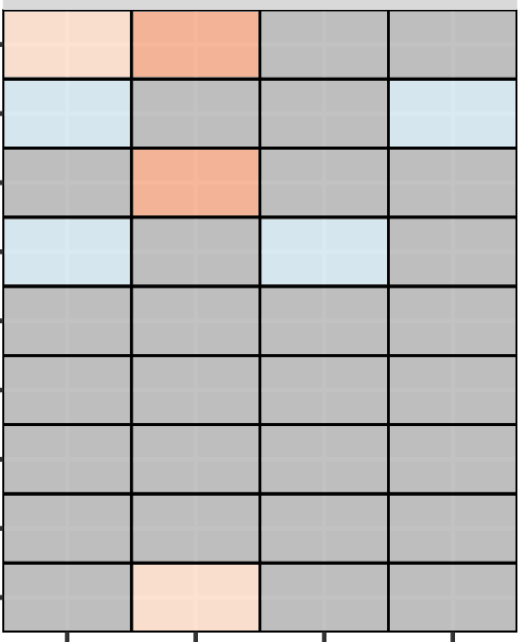

Fall Wtr SprSum

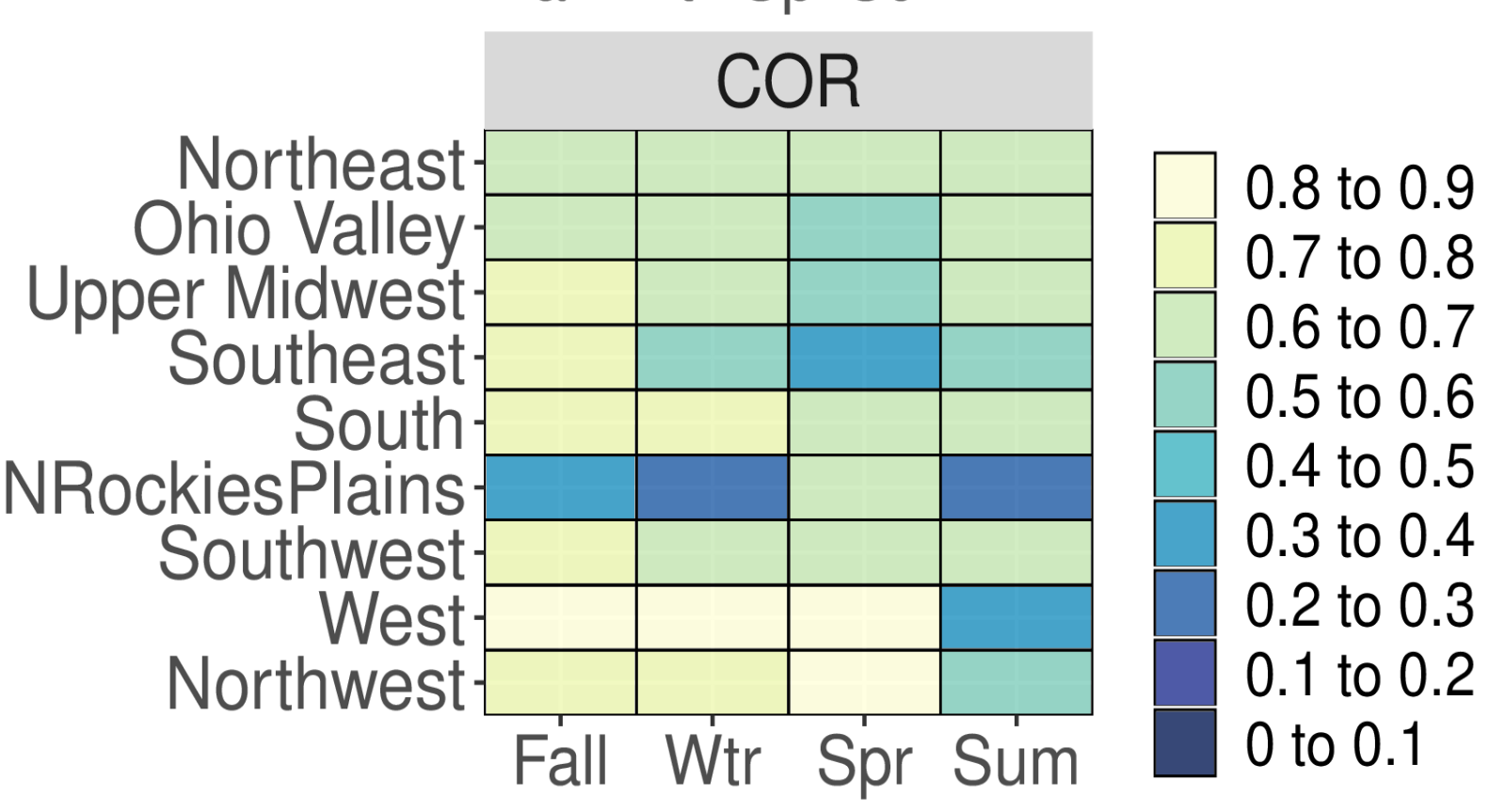

Figure S28. Categorical NMB (\%), MB ( $\left.\mu \mathrm{g} \mathrm{m}^{-3}\right)$, RMSE $\left(\mu \mathrm{g} \mathrm{m}^{-3}\right)$, and Pearson correlation values for EC for all AQS sites based on season and NOAA climate region for the CMAQ531_WRF411_M3Dry_BiDi simulation. 


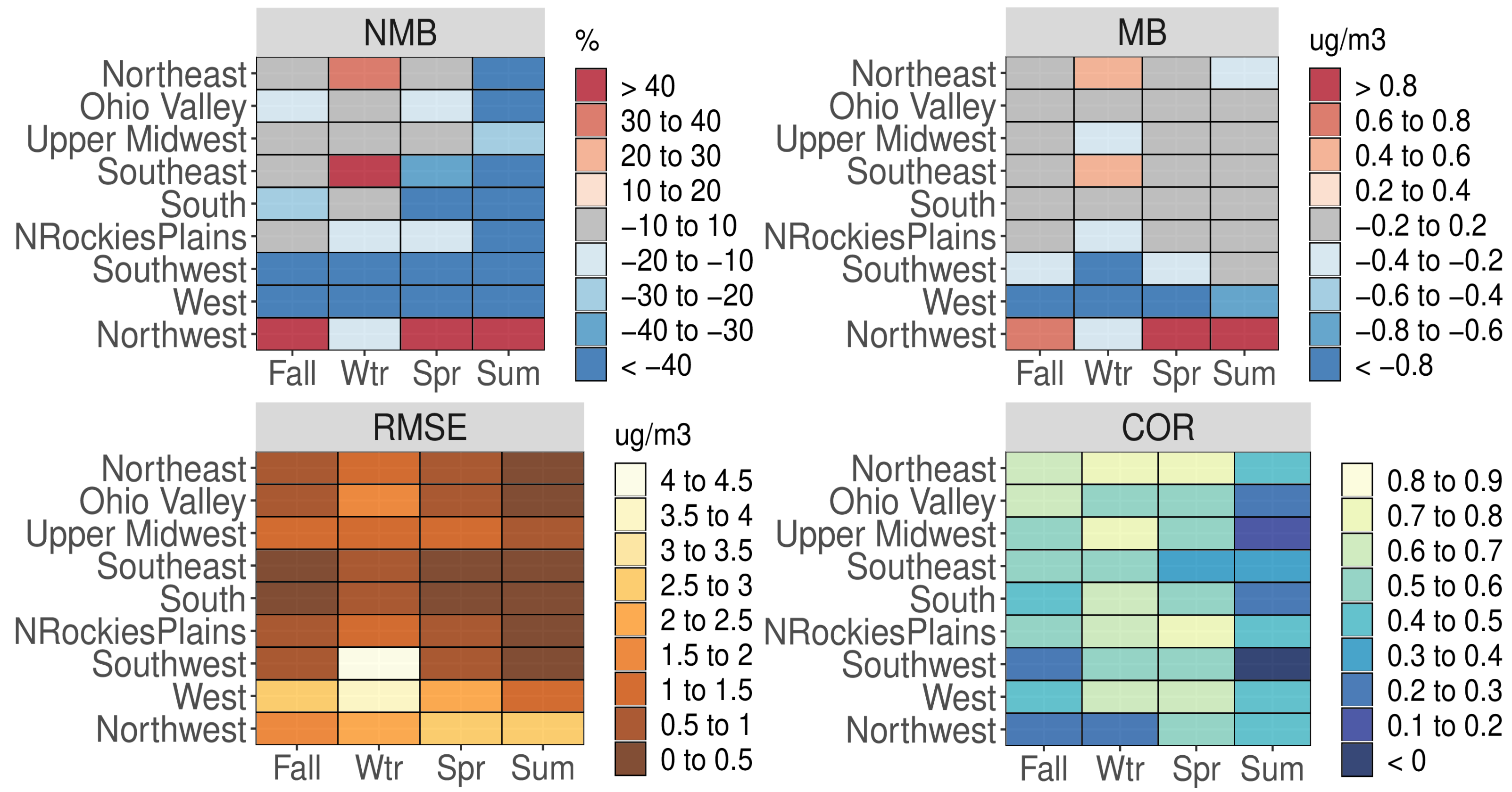

Figure S29. Categorical NMB (\%), MB $\left(\mu \mathrm{g} \mathrm{m}^{-3}\right)$, RMSE $\left(\mu \mathrm{g} \mathrm{m}^{-3}\right)$, and Pearson correlation values for $\mathrm{NO}_{3}{ }^{-}$for all CSN sites based on season and NOAA climate region for the CMAQ521 simulation. 


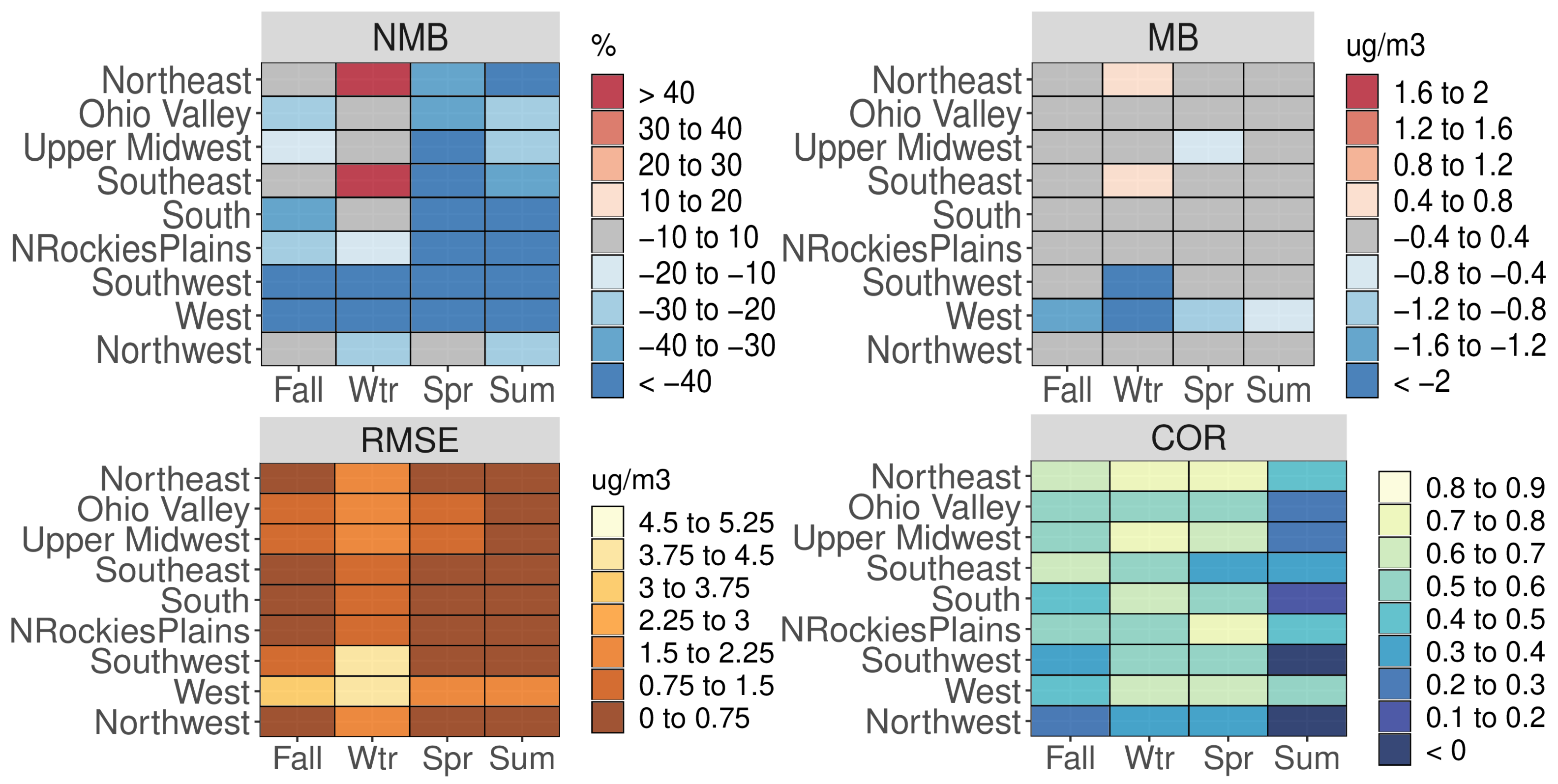

Figure S30. Categorical NMB (\%), MB $\left(\mu \mathrm{g} \mathrm{m}^{-3}\right)$, RMSE $\left(\mu \mathrm{g} \mathrm{m}^{-3}\right)$, and Pearson correlation values for $\mathrm{NO}_{3}{ }^{-}$for all CSN sites based on season and NOAA climate region for the CMAQ531_WRF411_M3Dry_BiDi simulation. 
NMB

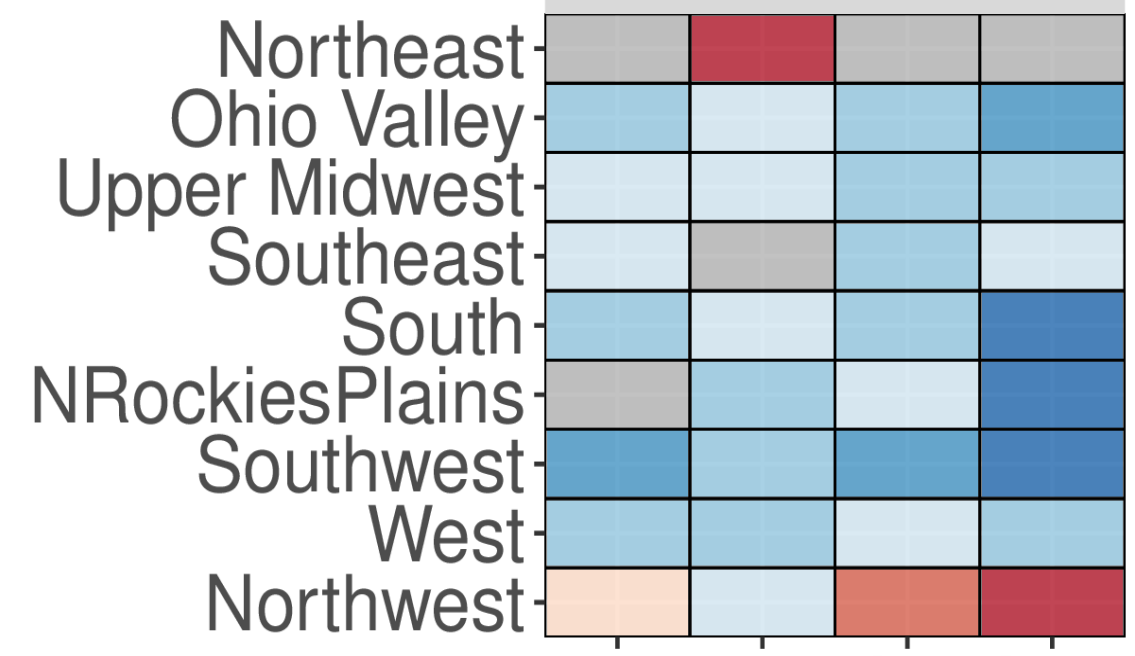

Fall Wtr Spr Sum

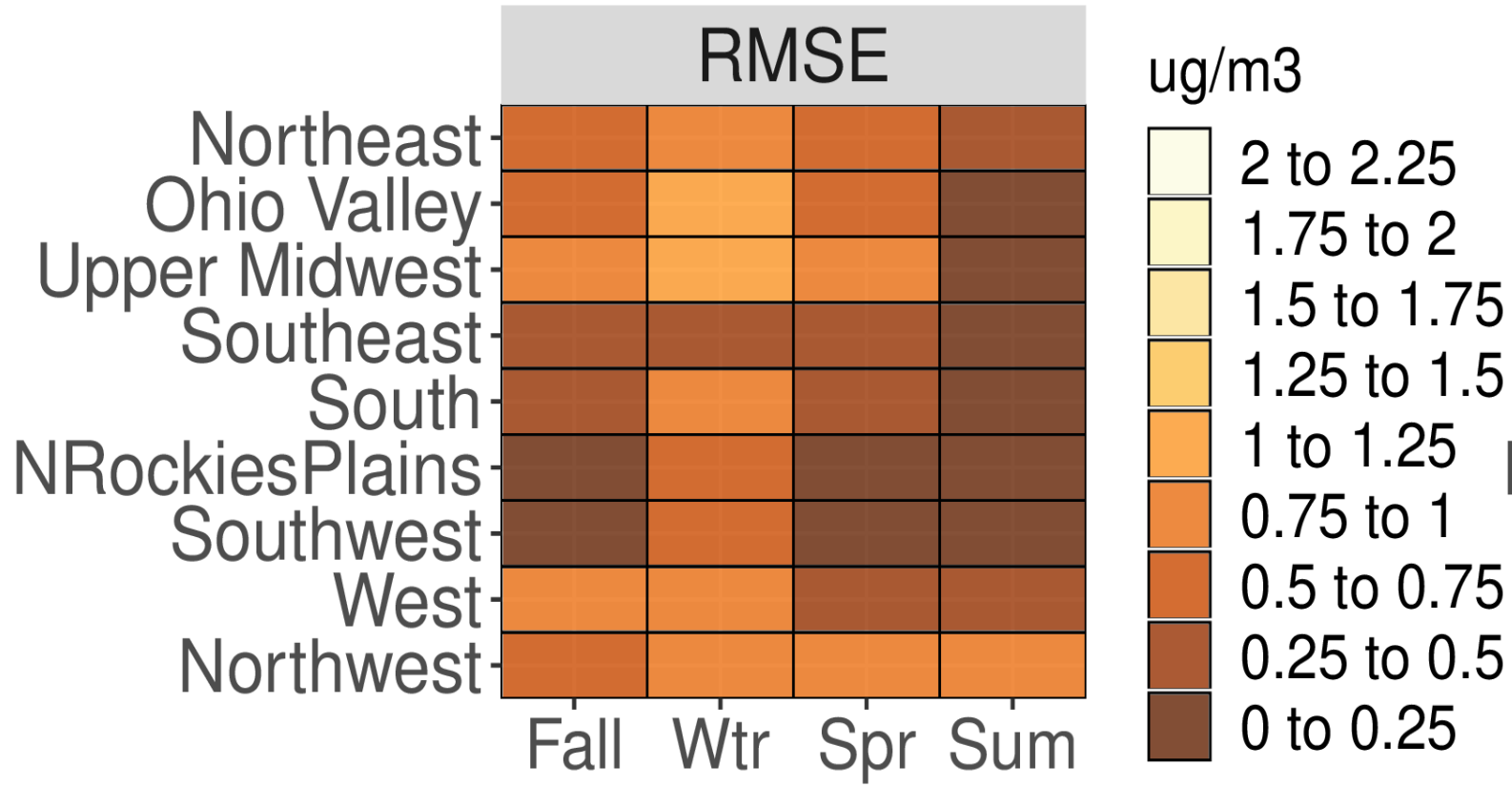

$\%$

$\square>80$

60 to 80

40 to 60

20 to 40

-20 to 20

-40 to -20

-60 to -40

-80 to -60

-100 to -80

Northwest

Fall Wtr Spr Sum COR

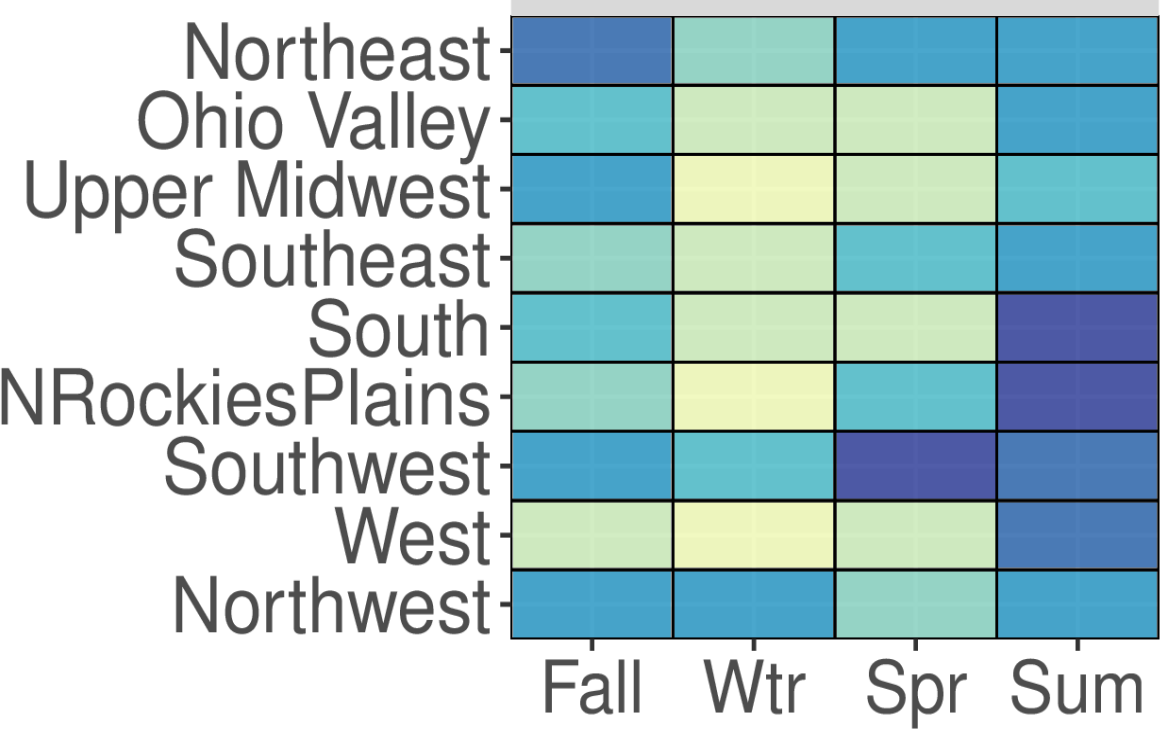

$\mathrm{ug} / \mathrm{m} 3$

0.4 to 0.5

0.3 to 0.4

0.2 to 0.3

0.1 to 0.2

-0.1 to 0.1

-0.2 to -0.1

-0.3 to -0.2

-0.4 to -0.3

-0.5 to -0.4

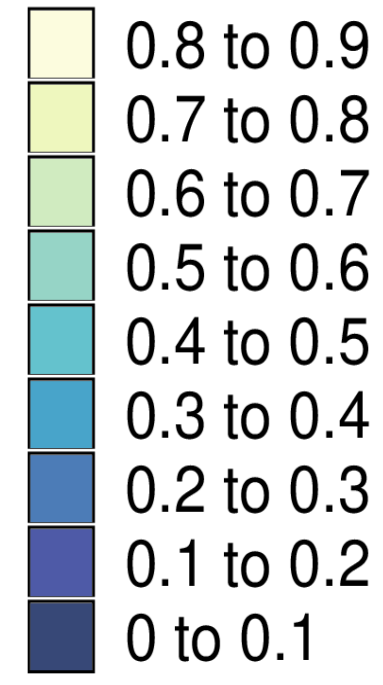

Figure S31. Categorical NMB (\%), MB $\left(\mu \mathrm{g} \mathrm{m}^{-3}\right)$, RMSE $\left(\mu \mathrm{g} \mathrm{m}^{-3}\right)$, and Pearson correlation values for $\mathrm{NO}_{3}^{-}$for all IMPROVE sites based on season and NOAA climate region for the CMAQ521 simulation. 


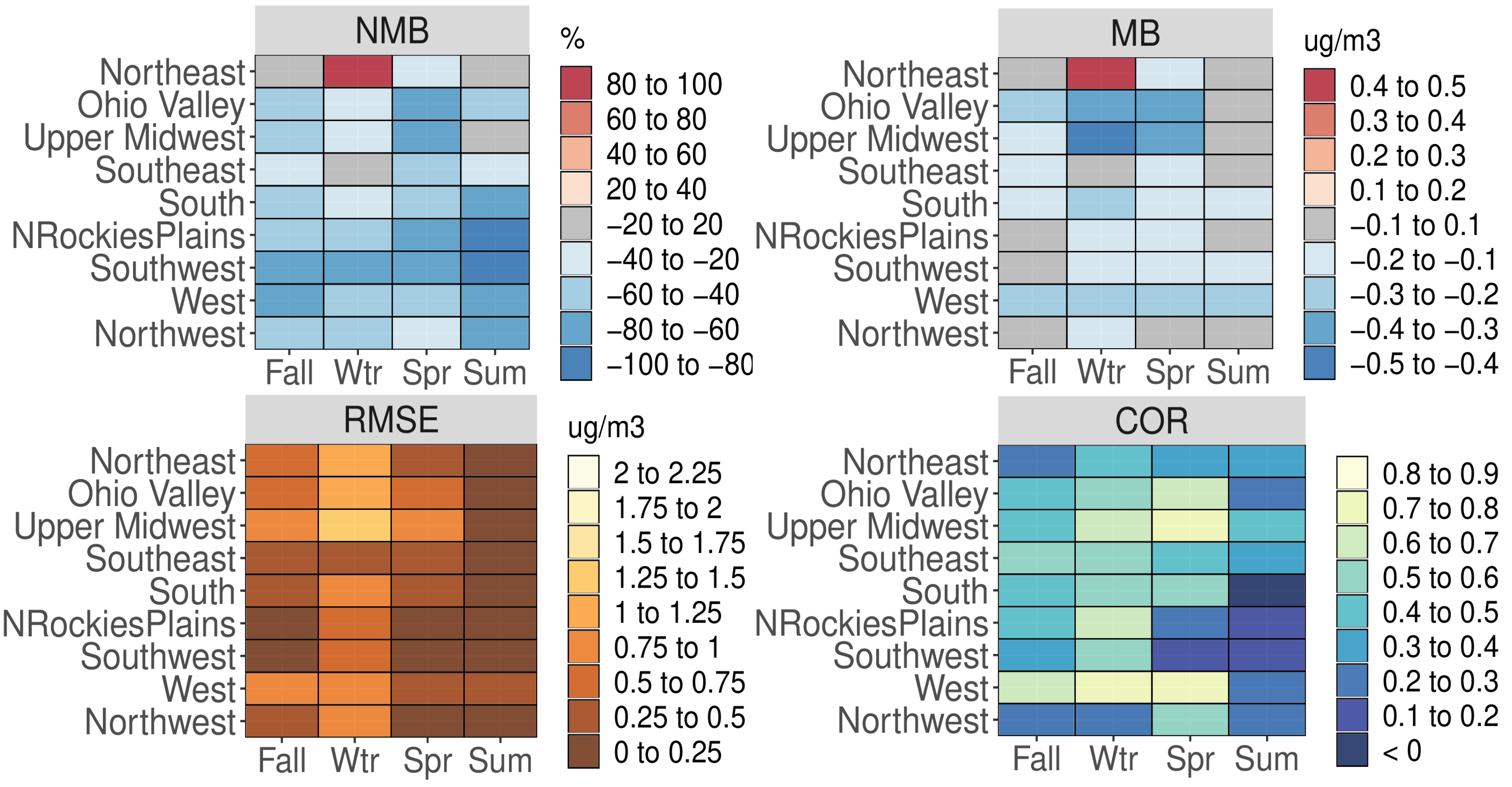

Figure S32. Categorical NMB (\%), MB $\left(\mu \mathrm{g} \mathrm{m}^{-3}\right)$, RMSE $\left(\mu \mathrm{g} \mathrm{m}^{-3}\right)$, and Pearson correlation values for $\mathrm{NO}_{3}{ }^{-}$for all IMPROVE sites based on season and NOAA climate region for the CMAQ531_WRF411_M3Dry_BiDi simulation. 


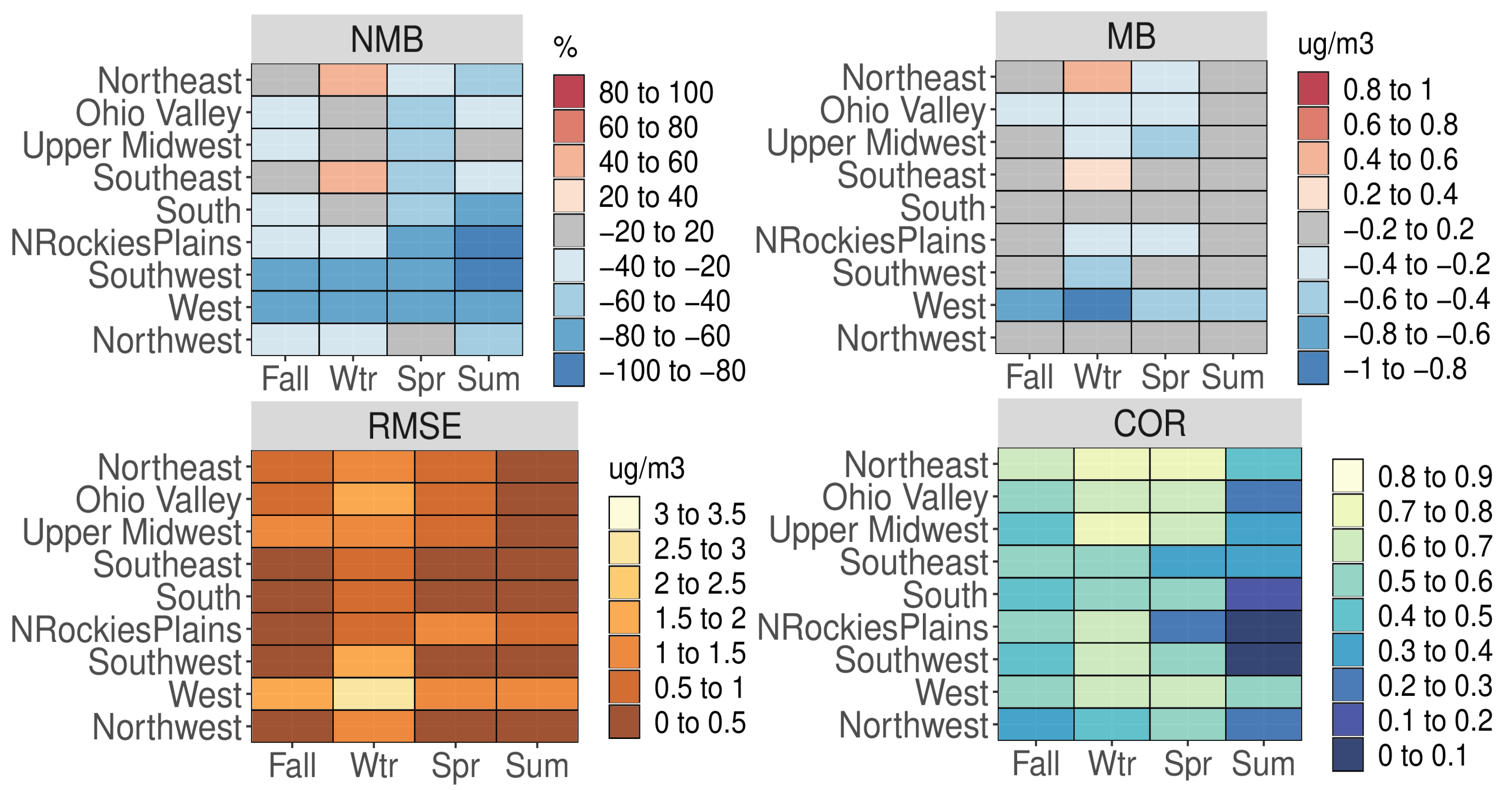

Figure S34. Categorical NMB (\%), MB $\left(\mu \mathrm{g} \mathrm{m}^{-3}\right)$, RMSE $\left(\mu \mathrm{g} \mathrm{m}^{-3}\right)$, and Pearson correlation values for $\mathrm{NO}_{3}{ }^{-}$for all AQS sites based on season and NOAA climate region for the CMAQ531_WRF411_M3Dry_BiDi simulation. 
NMB
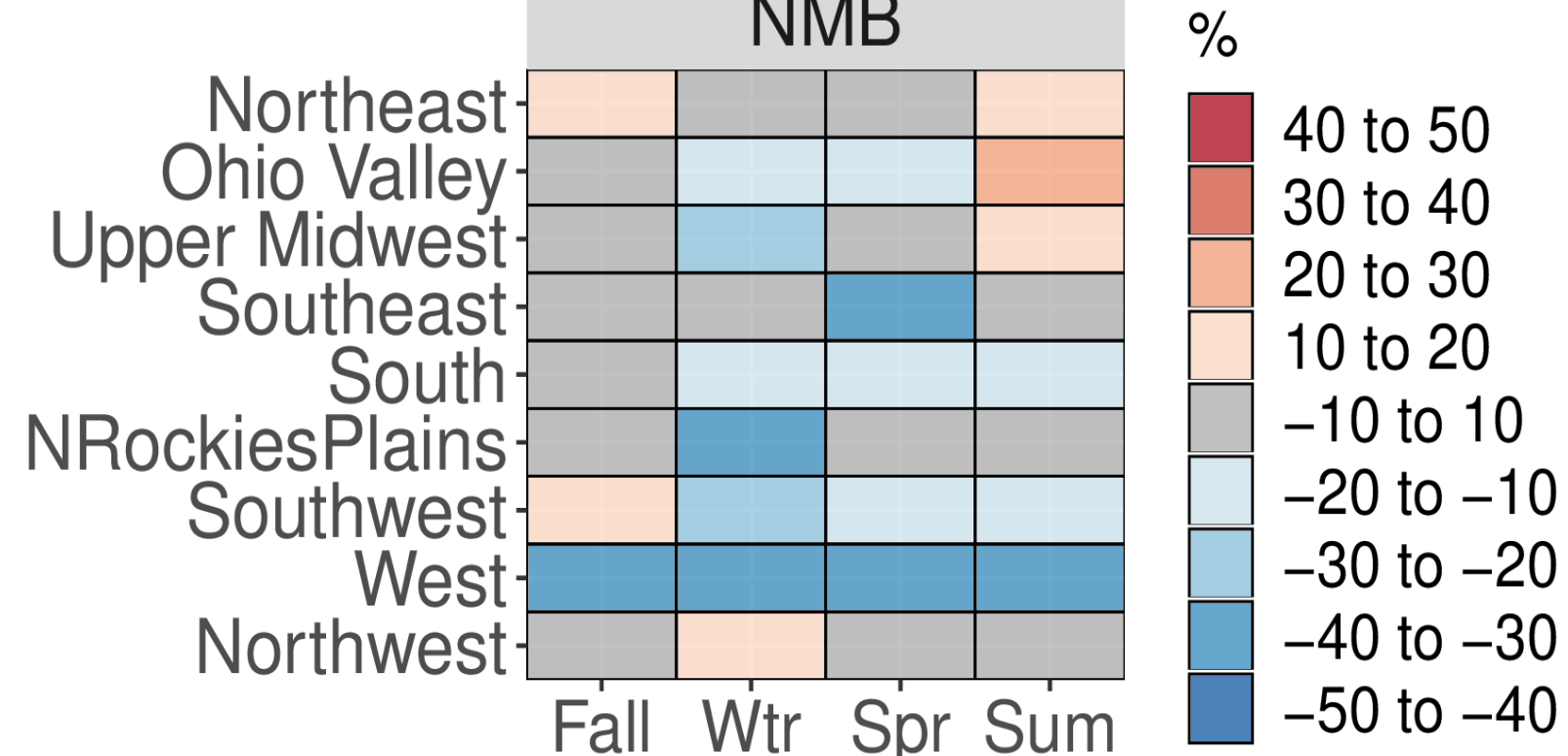

$\mathrm{MB}$
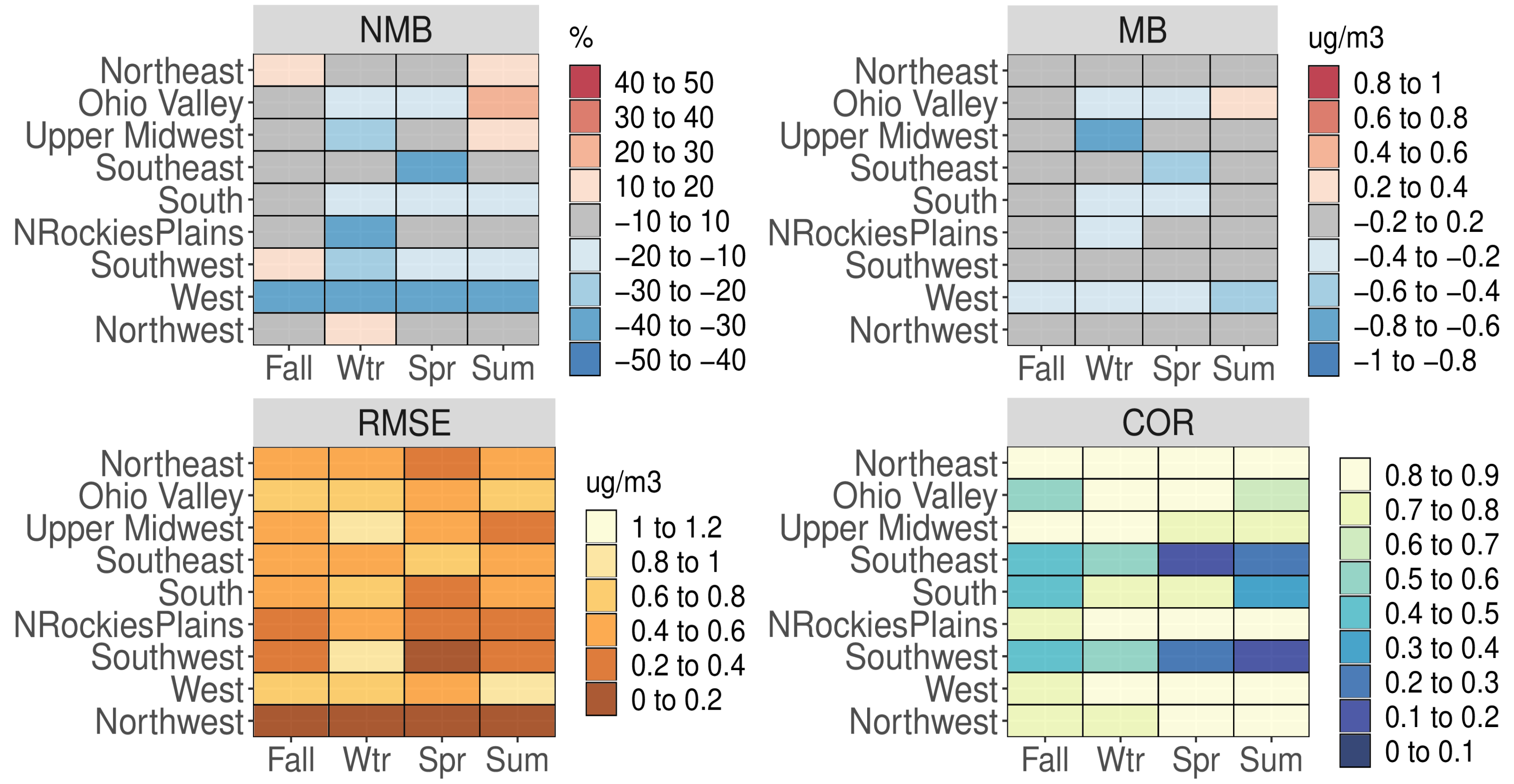

Figure S35. Categorical NMB (\%), MB $\left(\mu \mathrm{g} \mathrm{m}^{-3}\right)$, RMSE $\left(\mu \mathrm{g} \mathrm{m}^{-3}\right)$, and Pearson correlation values for $\mathrm{TNO}_{3}{ }^{-}$for all CASTNet sites based on season and NOAA climate region for the CMAQ521 simulation. 


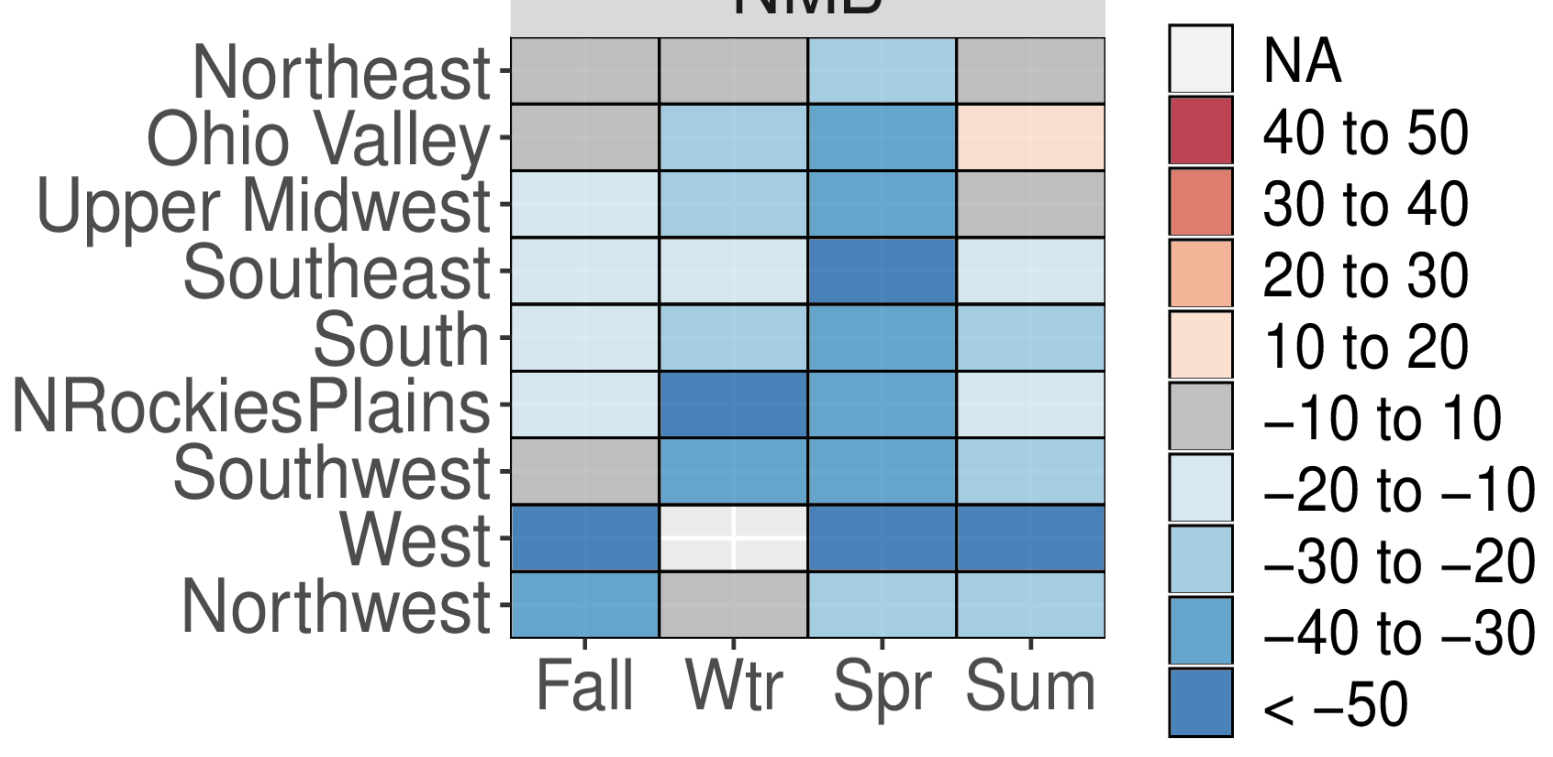

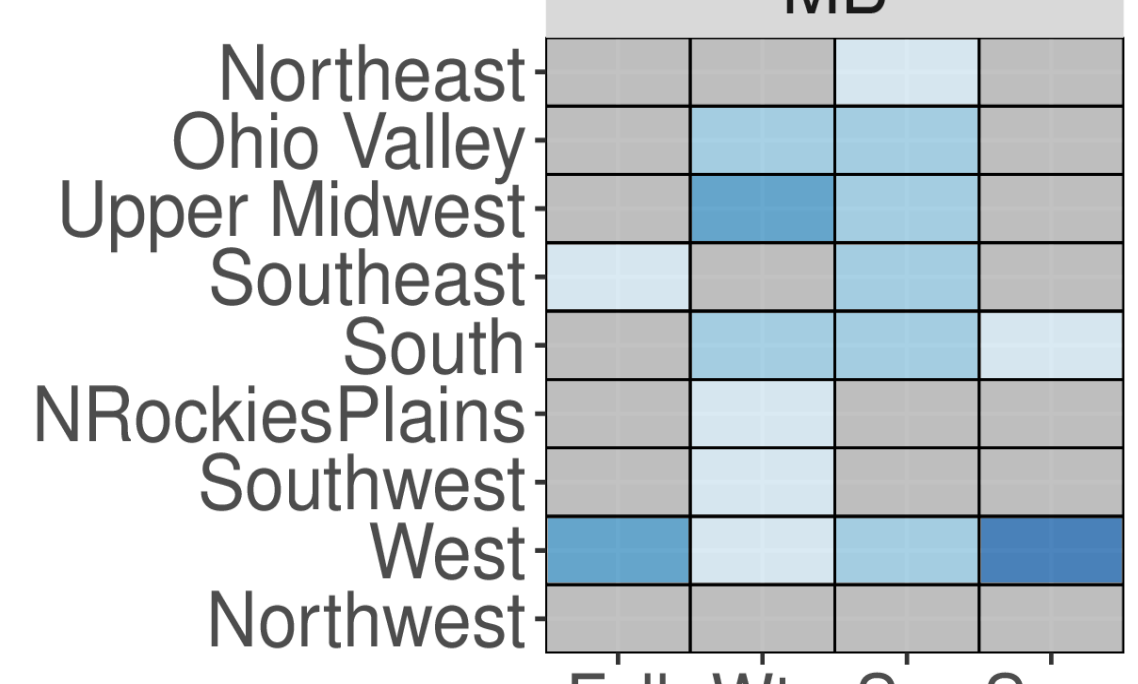

Fall Wtr Spr Sum

Fall W'tr Spr Sum

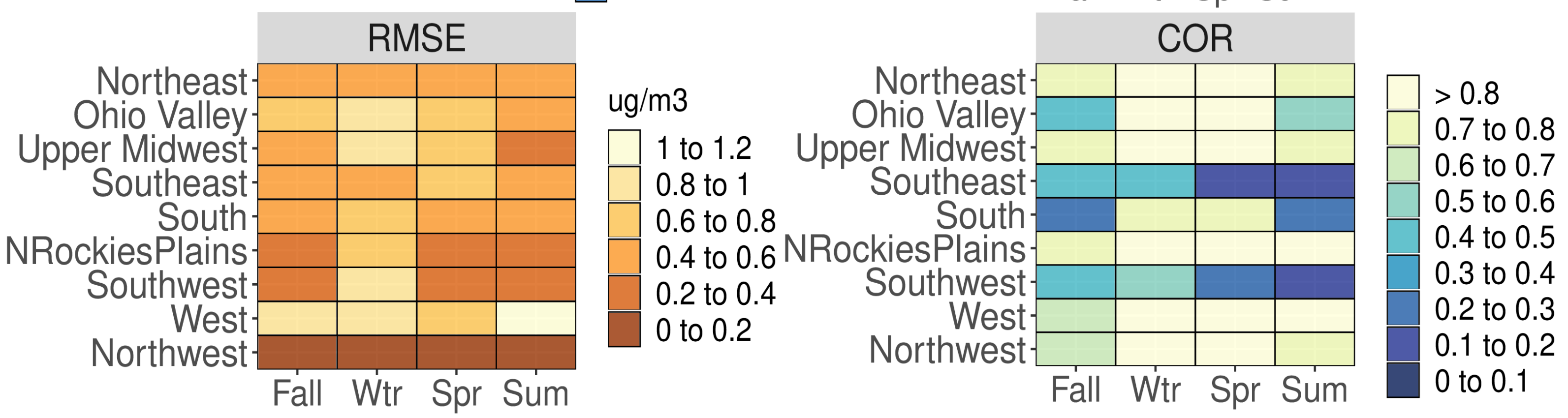

$\mathrm{ug} / \mathrm{m} 3$

0.8 to 1

0.6 to 0.8

0.4 to 0.6

0.2 to 0.4

-0.2 to 0.2

-0.4 to -0.2

-0.6 to -0.4

-0.8 to -0.6

-1 to -0.8

Figure S36. Categorical NMB (\%), MB $\left(\mu \mathrm{g} \mathrm{m}^{-3}\right)$, RMSE $\left(\mu \mathrm{g} \mathrm{m}^{-3}\right)$, and Pearson correlation values for $\mathrm{TNO}_{3}{ }^{-}$for all CASTNet sites based on season and NOAA climate region for the CMAQ531_WRF411_M3Dry_BiDi simulation. 


\section{NMB}

Ohio Valley Upper Midwest

Southeast South NRockiesPlains Southwest West Northwest

Fall Wtr Spr Sum

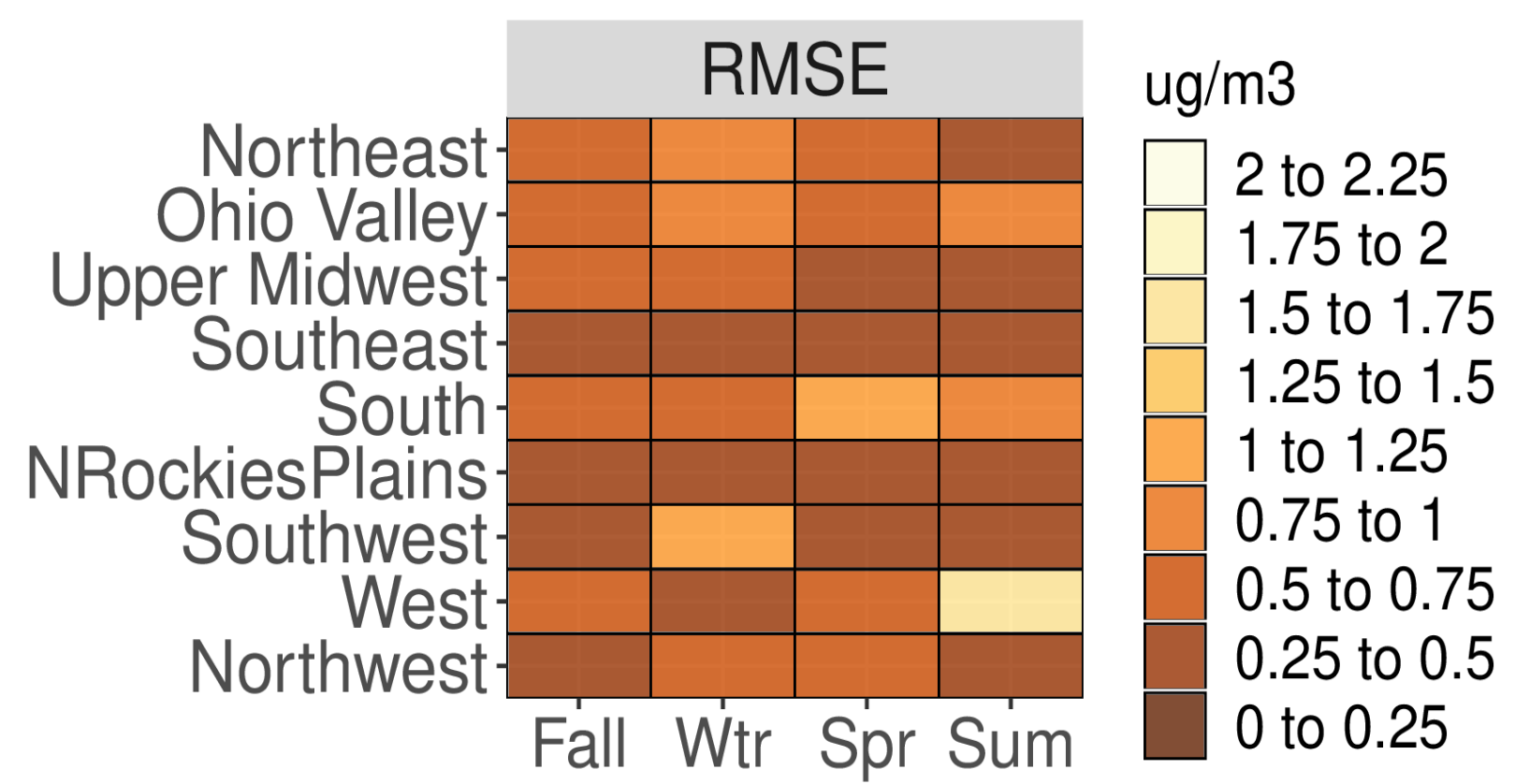

MB

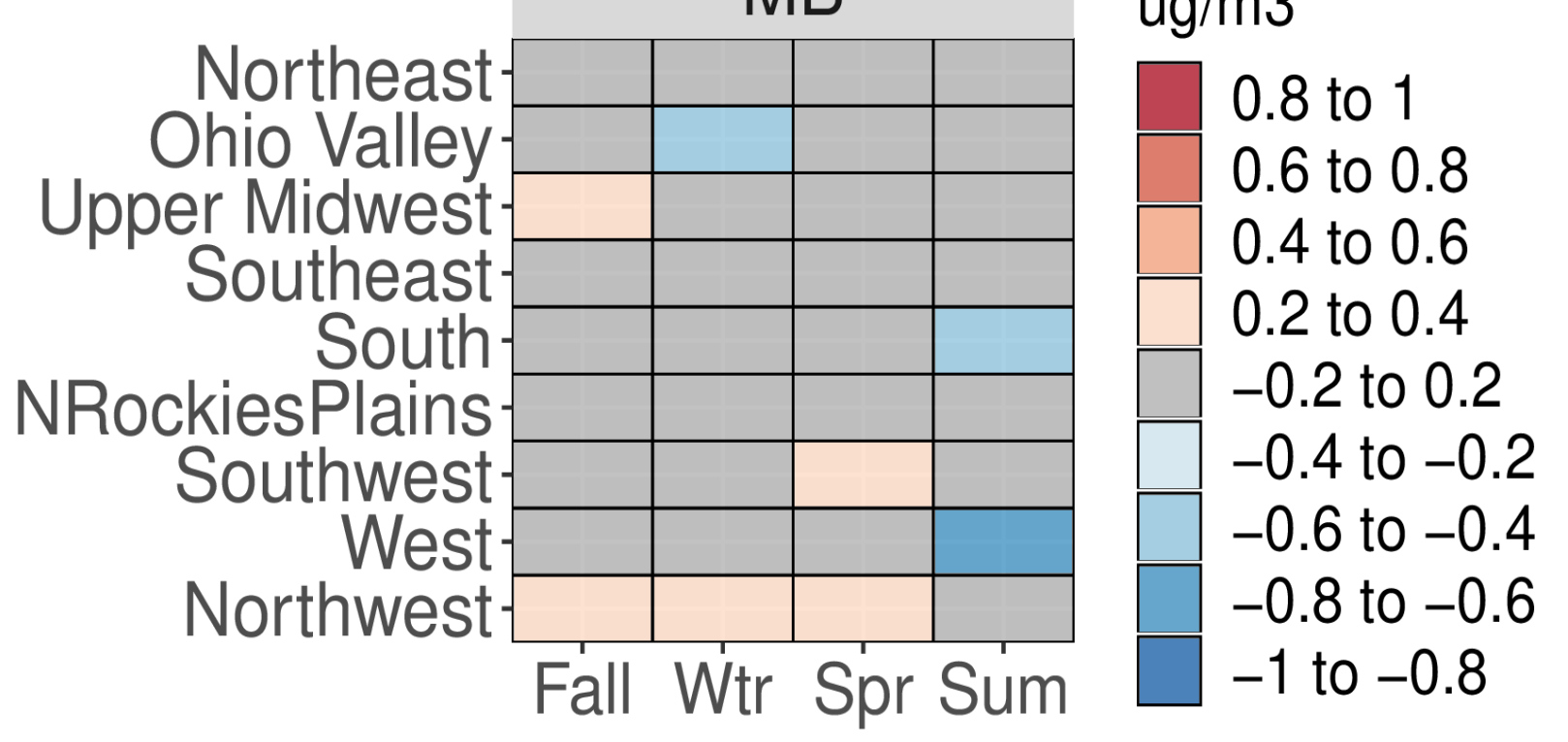

Figure S37. Categorical NMB (\%), MB $\left(\mu \mathrm{g} \mathrm{m}^{-3}\right)$, RMSE $\left(\mu \mathrm{g} \mathrm{m}^{-3}\right)$, and Pearson correlation values for $\mathrm{SO}_{4}{ }^{2-}$ for all CSN sites based on season and NOAA climate region for the CMAQ521 simulation. 


\section{NMB}

Ohio Valley

Upper Midwest

Southeast

South

NRockiesPlains

Southwest West

Northwest

Fall Wtr Spr Sum

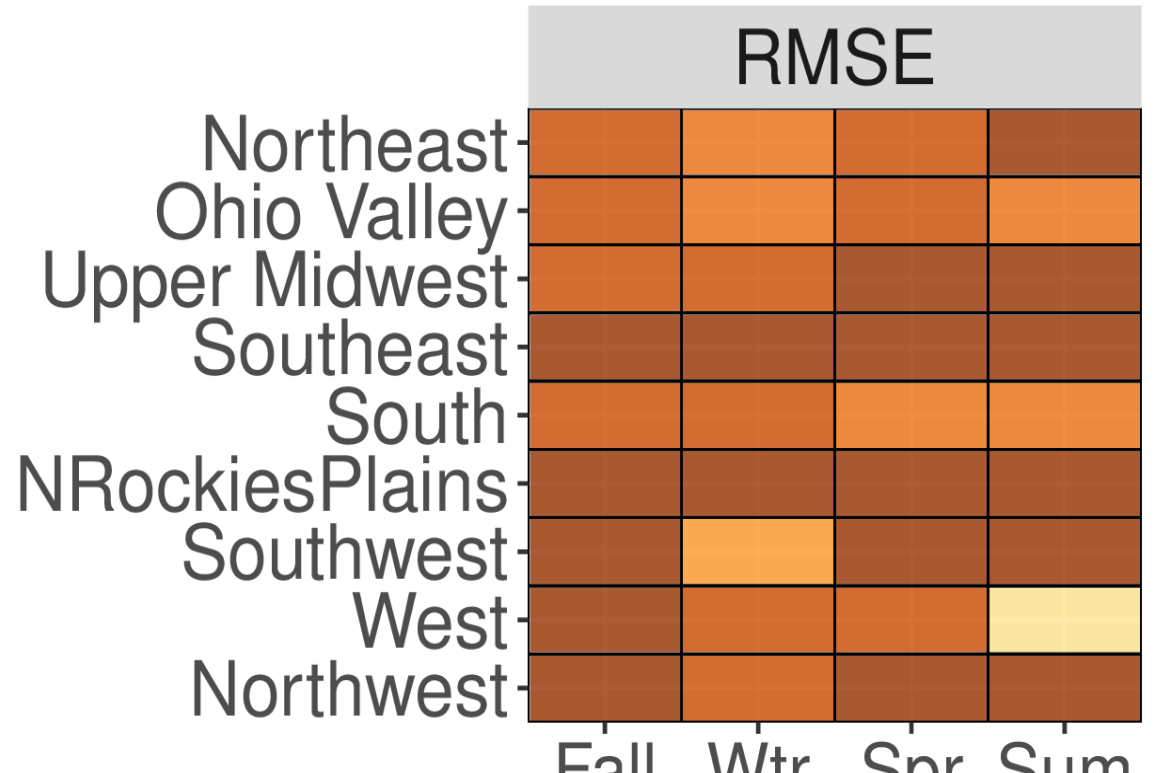

Fall Wtr Spr Sum
$\%$

$>80$

60 to 80

40 to 60

20 to 40

-20 to 20

-40 to -20

-60 to -40

-80 to -60

-100 to -80

\section{$\mathrm{ug} / \mathrm{m} 3$}

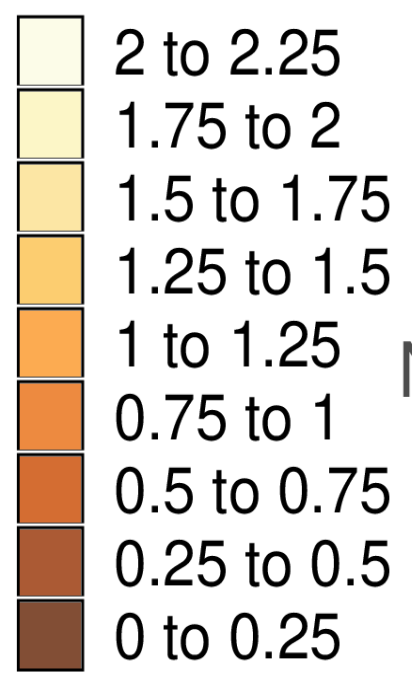

MB
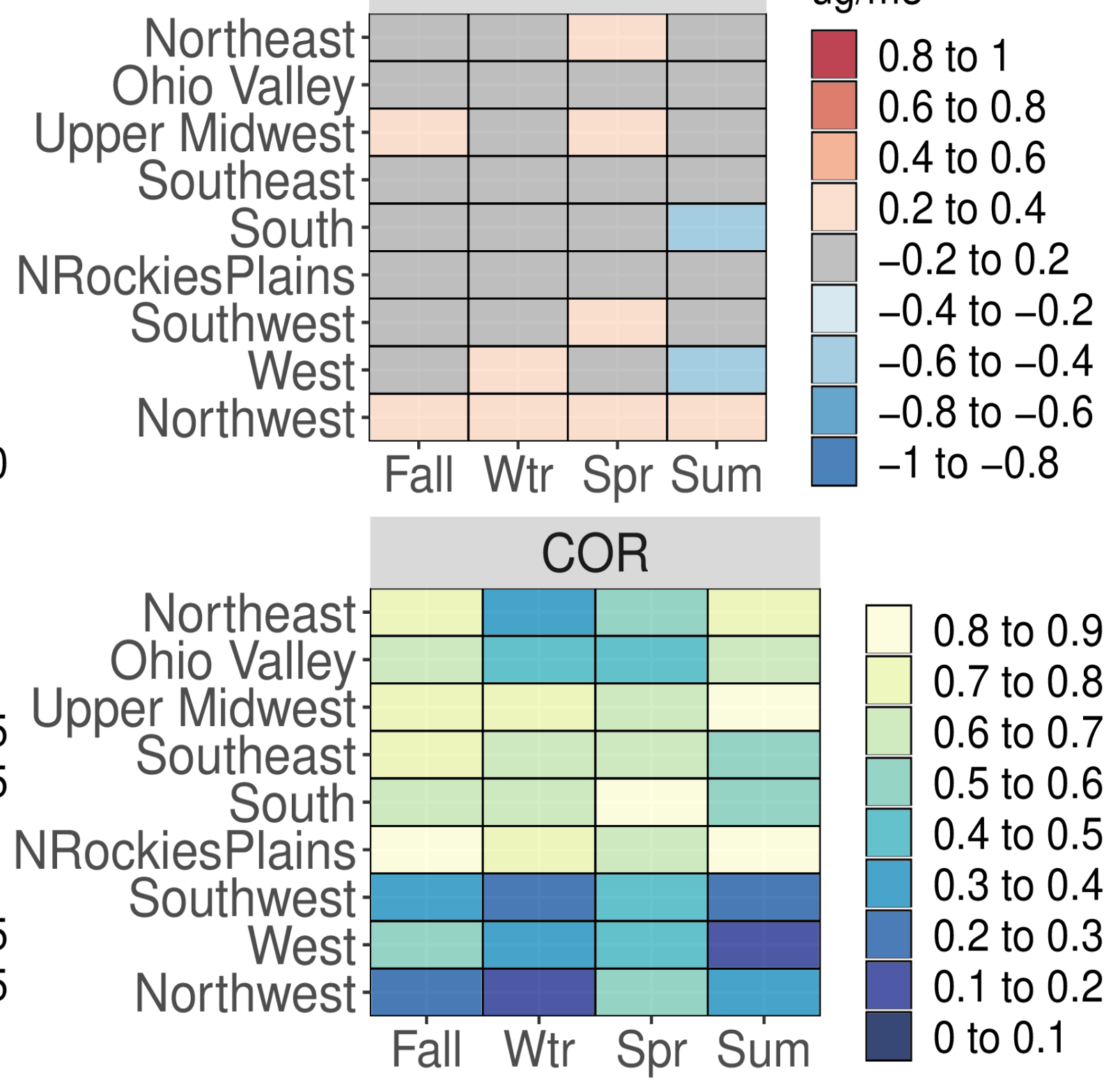

Figure S38. Categorical NMB (\%), MB $\left(\mu \mathrm{g} \mathrm{m}^{-3}\right)$, RMSE $\left(\mu \mathrm{g} \mathrm{m}^{-3}\right)$, and Pearson correlation values for $\mathrm{SO}_{4}{ }^{2-}$ for all $\mathrm{CSN}$ sites based on season and NOAA climate region for the CMAQ531_WRF411_M3Dry_BiDi simulation. 


\section{NMB}

Ohio Valley Upper Midwest

Southeast South NRockiesPlains

Southwest Northwest
$\%$

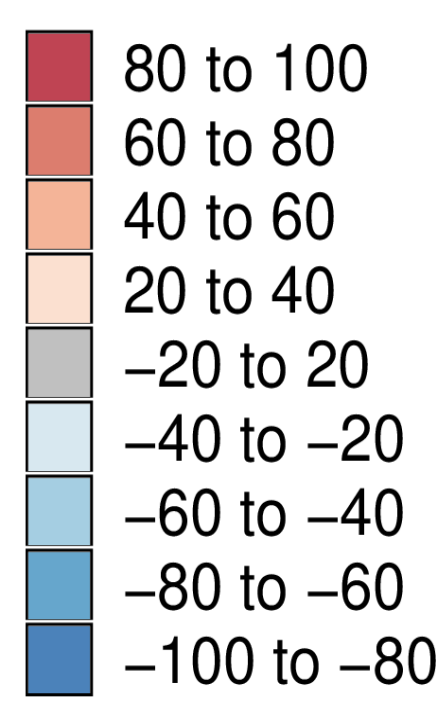

MB

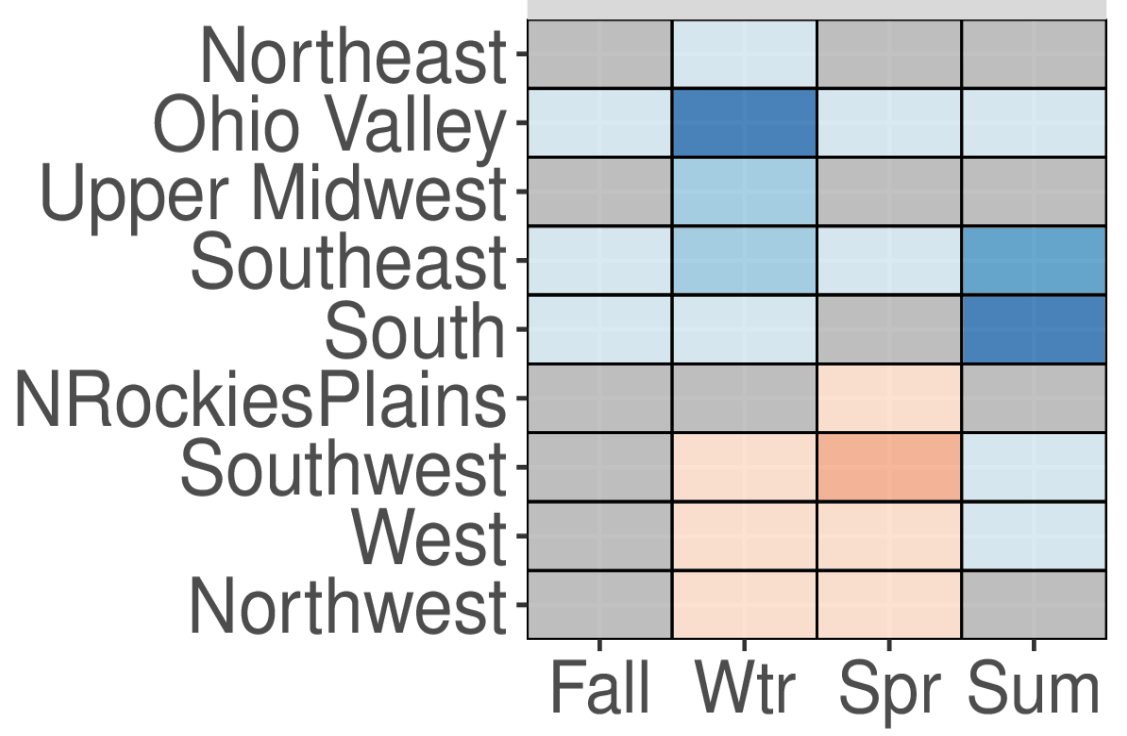

$\mathrm{ug} / \mathrm{m} 3$

0.4 to 0.5 0.3 to 0.4 0.2 to 0.3 0.1 to 0.2 -0.1 to 0.1 -0.2 to -0.1 -0.3 to -0.2 -0.4 to -0.3 -0.5 to -0.4

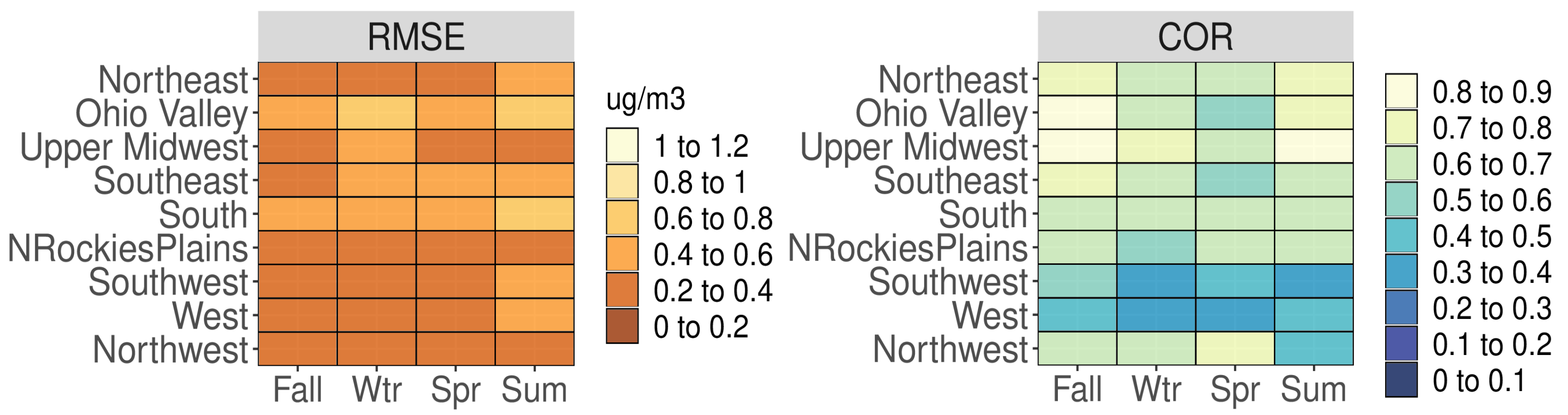

Figure S39. Categorical NMB (\%), MB $\left(\mu \mathrm{g} \mathrm{m}^{-3}\right)$, RMSE $\left(\mu \mathrm{g} \mathrm{m}^{-3}\right)$, and Pearson correlation values for $\mathrm{SO}_{4}{ }^{2-}$ for all IMPROVE sites based on season and NOAA climate region for the CMAQ521 simulation. 


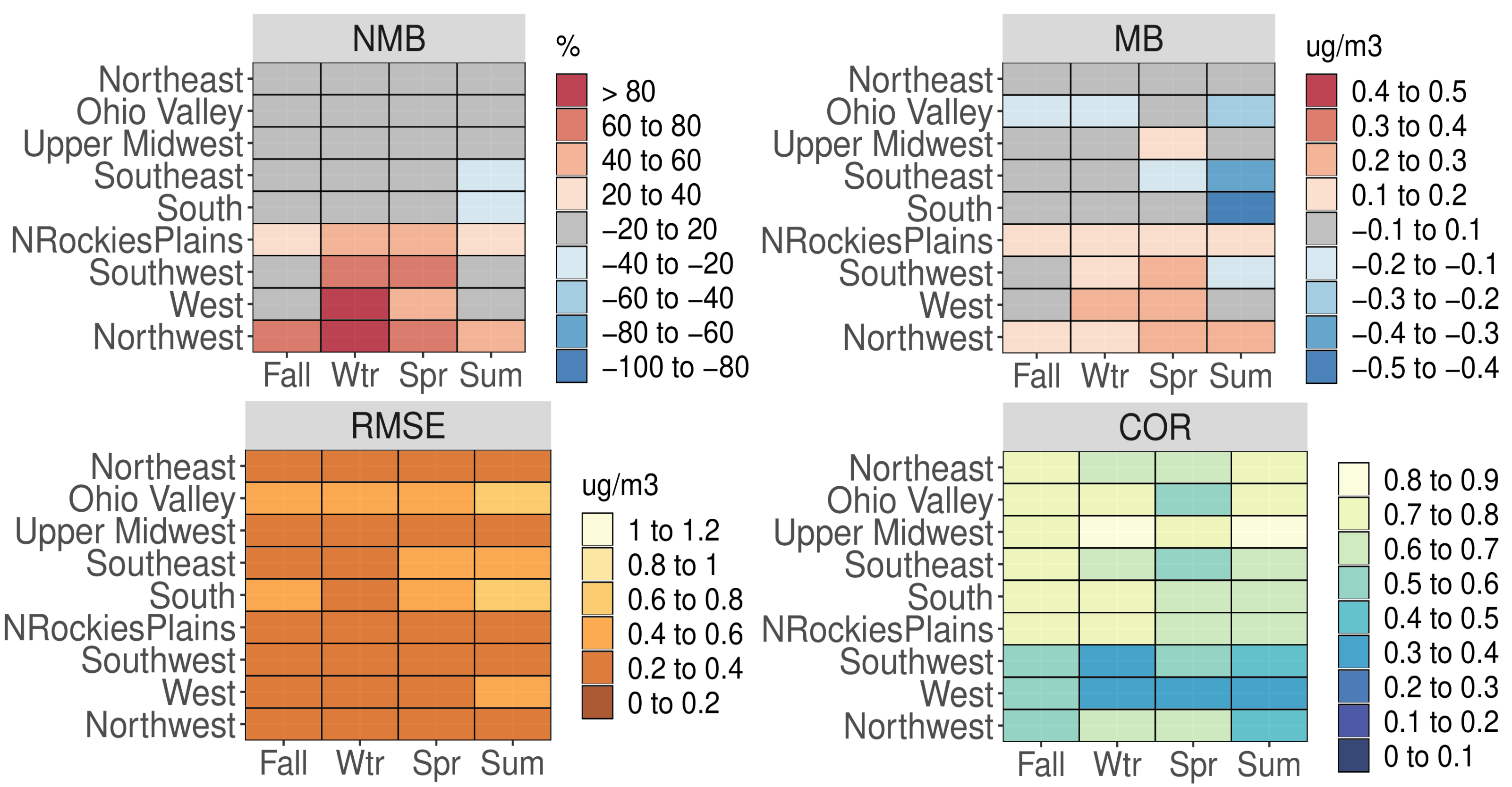

Figure S40. Categorical NMB (\%), MB ( $\left.\mu \mathrm{g} \mathrm{m}^{-3}\right)$, RMSE $\left(\mu \mathrm{g} \mathrm{m}^{-3}\right)$, and Pearson correlation values for $\mathrm{SO}_{4}{ }^{2-}$ for all IMPROVE sites based on season and NOAA climate region for the CMAQ531_WRF411_M3Dry_BiDi simulation. 


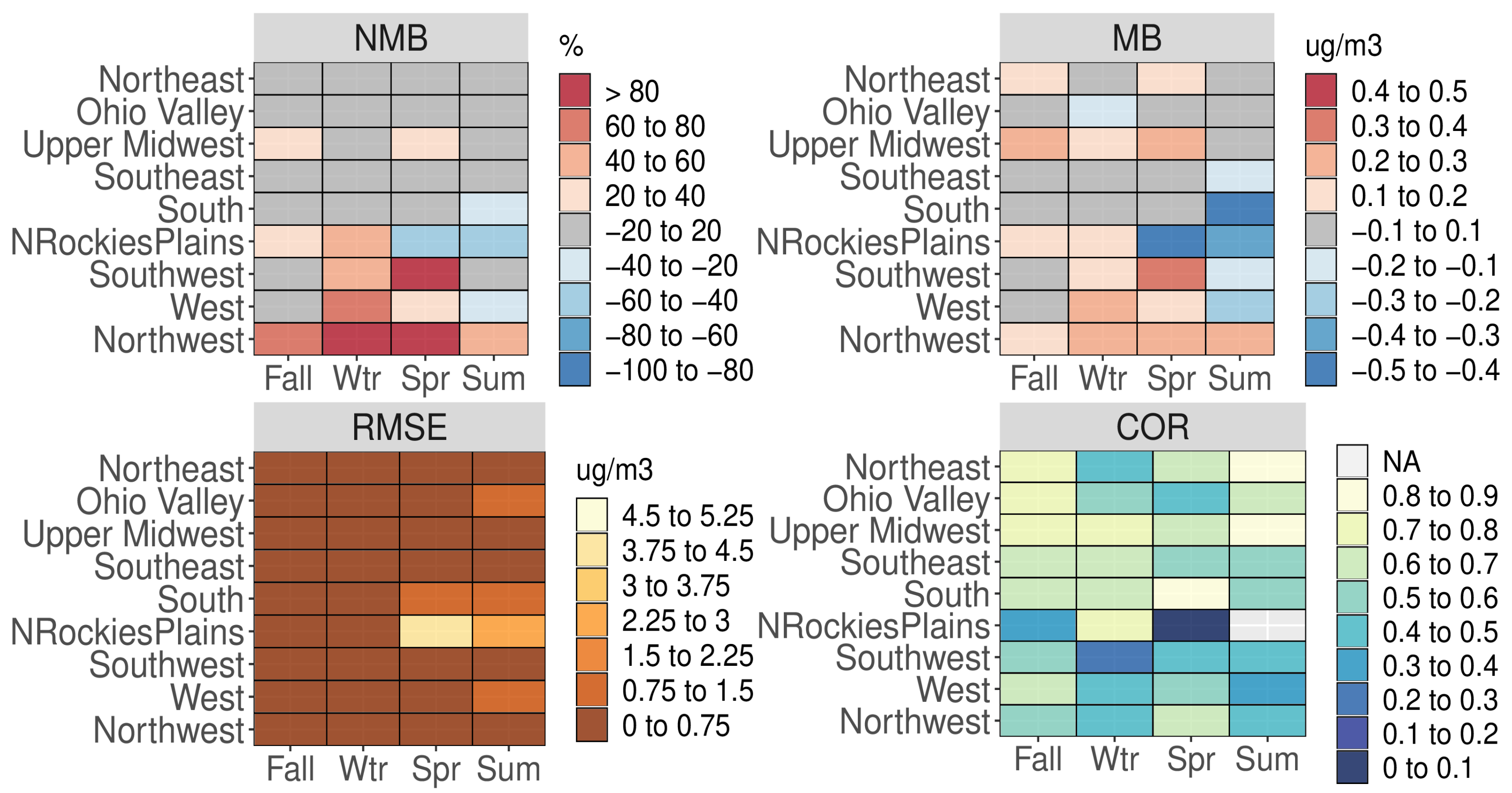

Figure S42. Categorical NMB (\%), MB $\left(\mu \mathrm{g} \mathrm{m}^{-3}\right)$, RMSE $\left(\mu \mathrm{g} \mathrm{m}^{-3}\right)$, and Pearson correlation values for $\mathrm{SO}_{4}{ }^{2-}$ for all AQS sites based on season and NOAA climate region for the CMAQ531_WRF411_M3Dry_BiDi simulation. 


\section{NMB}

Ohio Valley Upper Midwest

Southeast South

NRockiesPlains

Southwest West

Northwest
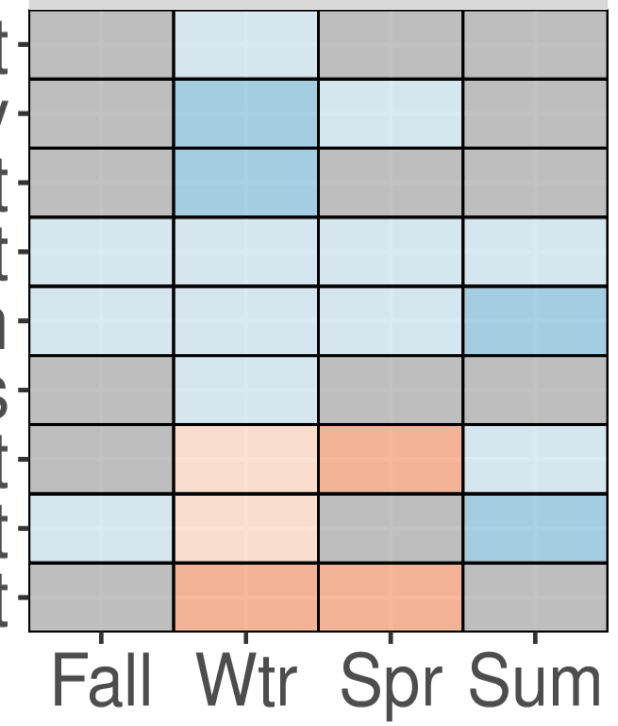

$\%$

RMSE

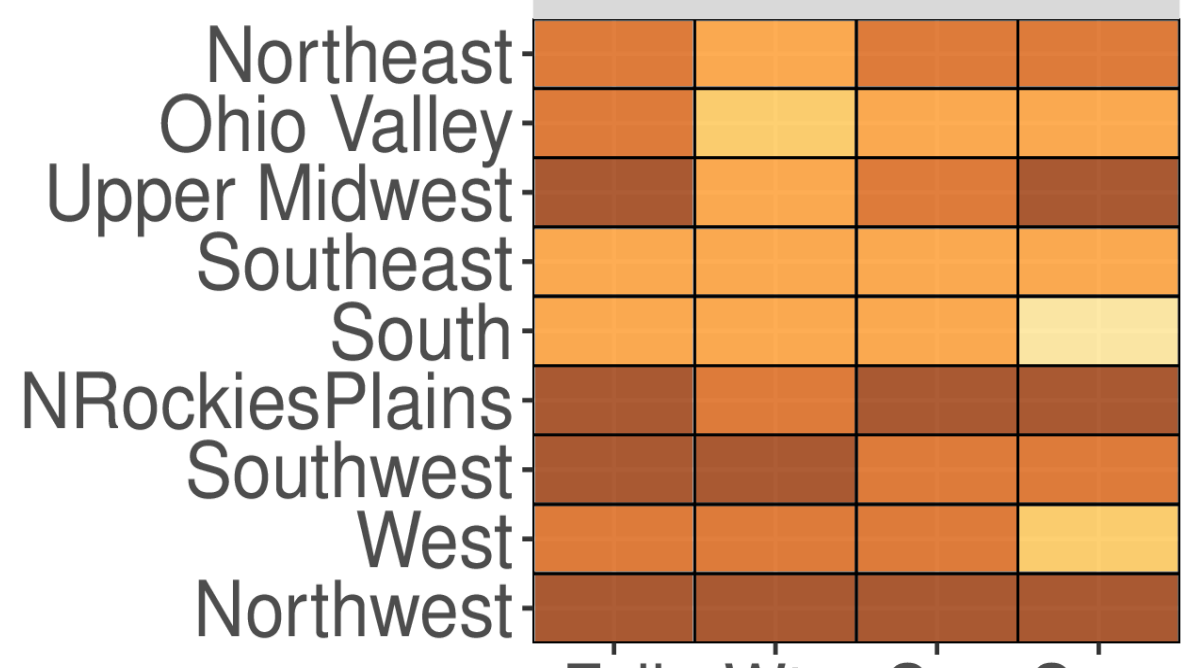

Fall Wtr Spr Sum $\mathrm{ug} / \mathrm{m} 3$

\begin{tabular}{|l|l|}
\hline & 1 to 1.2 \\
0.8 to 1 \\
0.6 to 0.8 \\
0.4 to 0.6 \\
0.2 to 0.4 \\
0 to 0.2
\end{tabular}

\section{MB}

80 to 100

60 to 80

40 to 60

20 to 40

-20 to 20

-40 to -20

-60 to -40

-80 to -60

-100 to -80

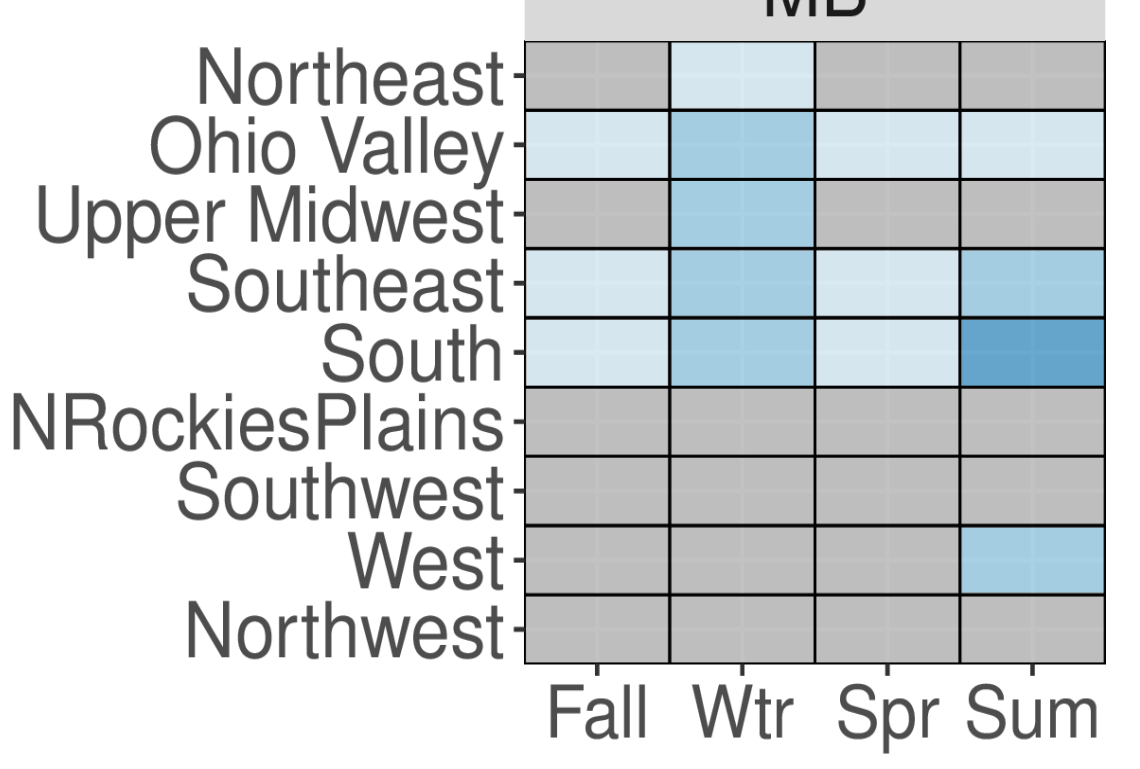

$\mathrm{ug} / \mathrm{m} 3$
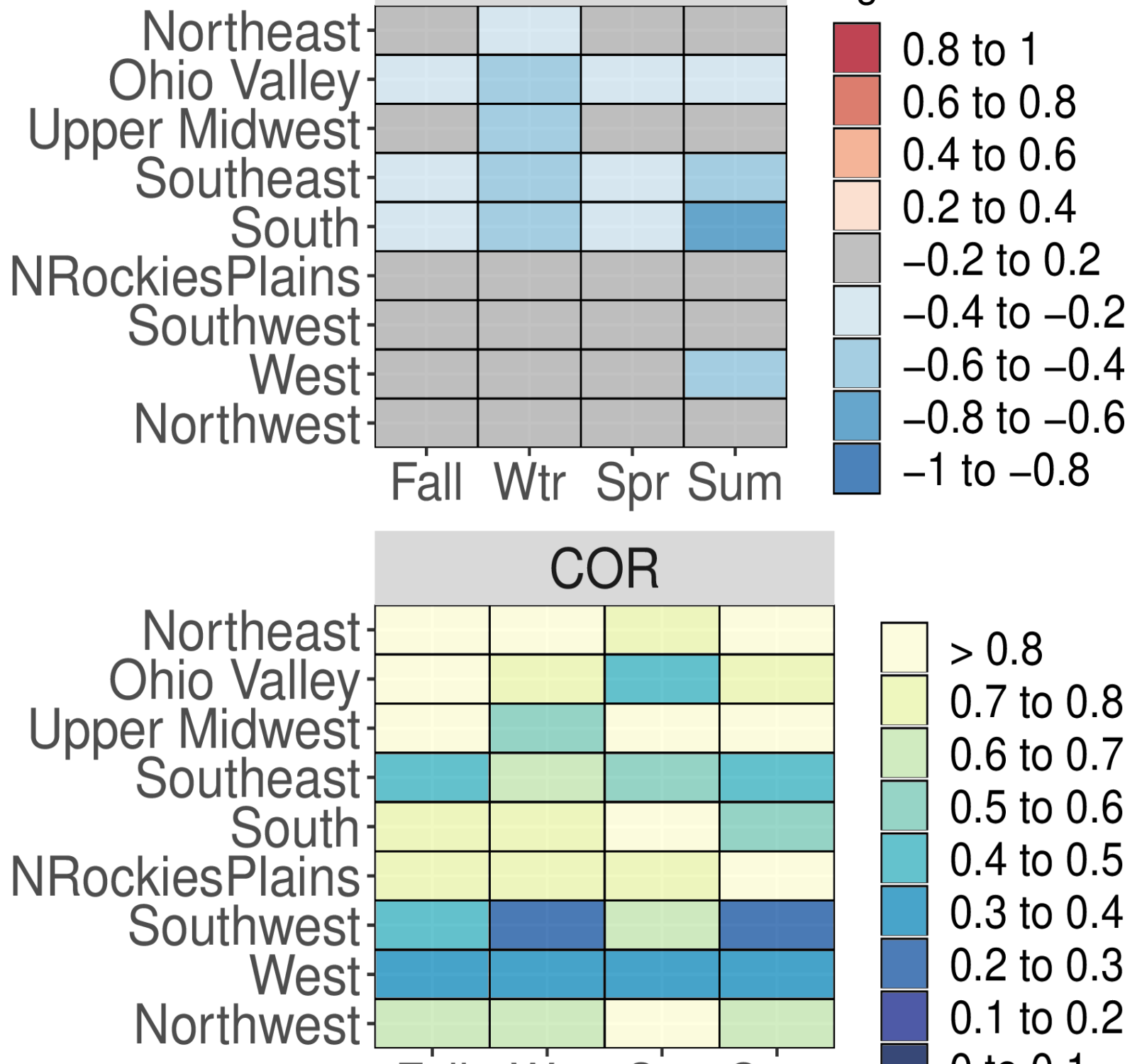

Fall Wtr Spr Sum

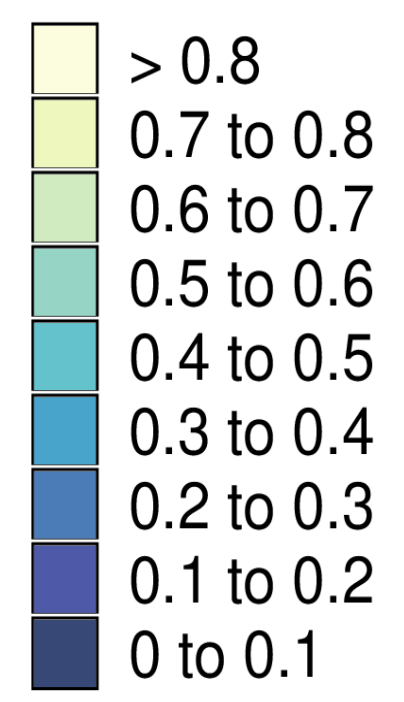

Figure S43. Categorical NMB (\%), MB $\left(\mu \mathrm{g} \mathrm{m}^{-3}\right)$, RMSE $\left(\mu \mathrm{g} \mathrm{m}^{-3}\right)$, and Pearson correlation values for $\mathrm{SO}_{4}{ }^{2-}$ for all CASTNet sites based on season and NOAA climate region for the CMAQ521 simulation. 


\section{NMB}

Ohio Valley

Upper Midwest

Southeast

South

NRockiesPlains

Southwest West

Northwest

Fall Wtr Spr Sum

\section{RMSE}

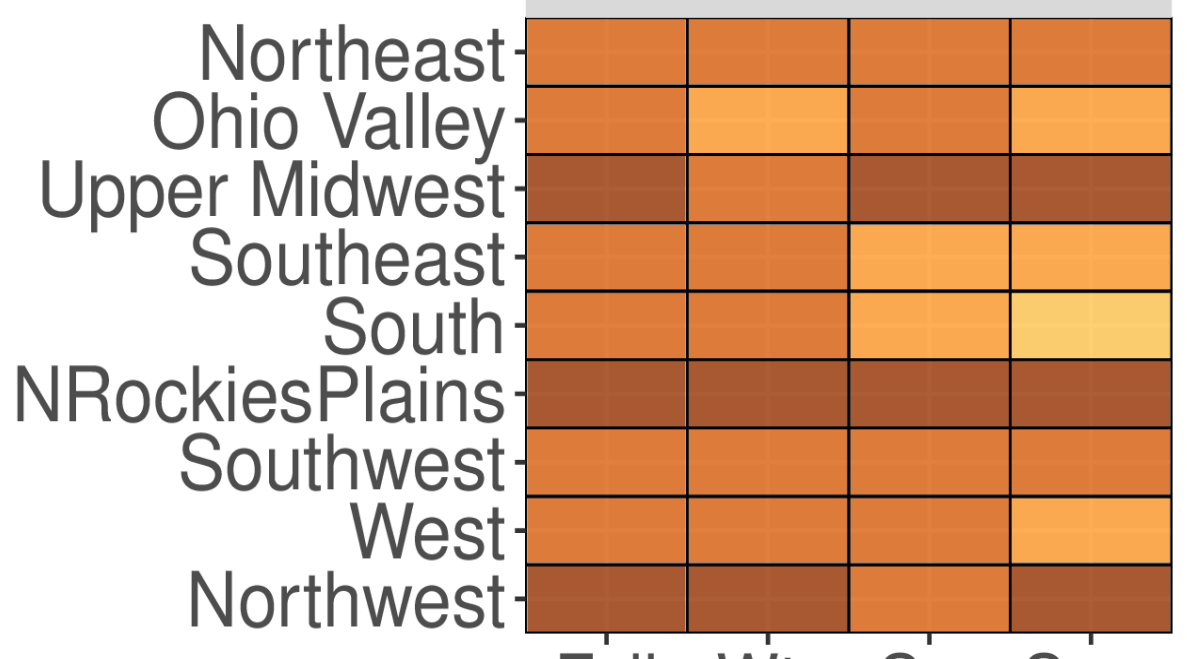

Fall Wtr Spr Sum
$\%$

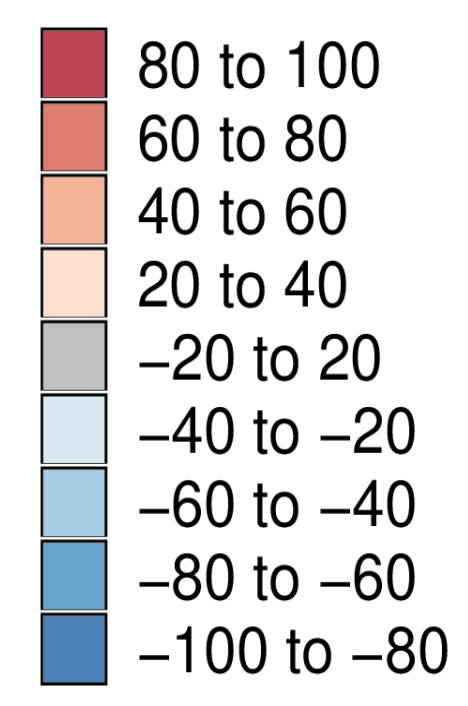

$\mathrm{ug} / \mathrm{m} 3$

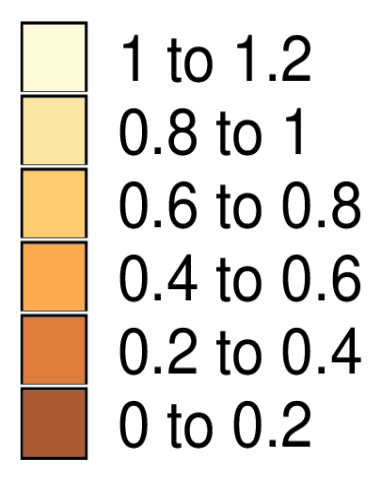

MB

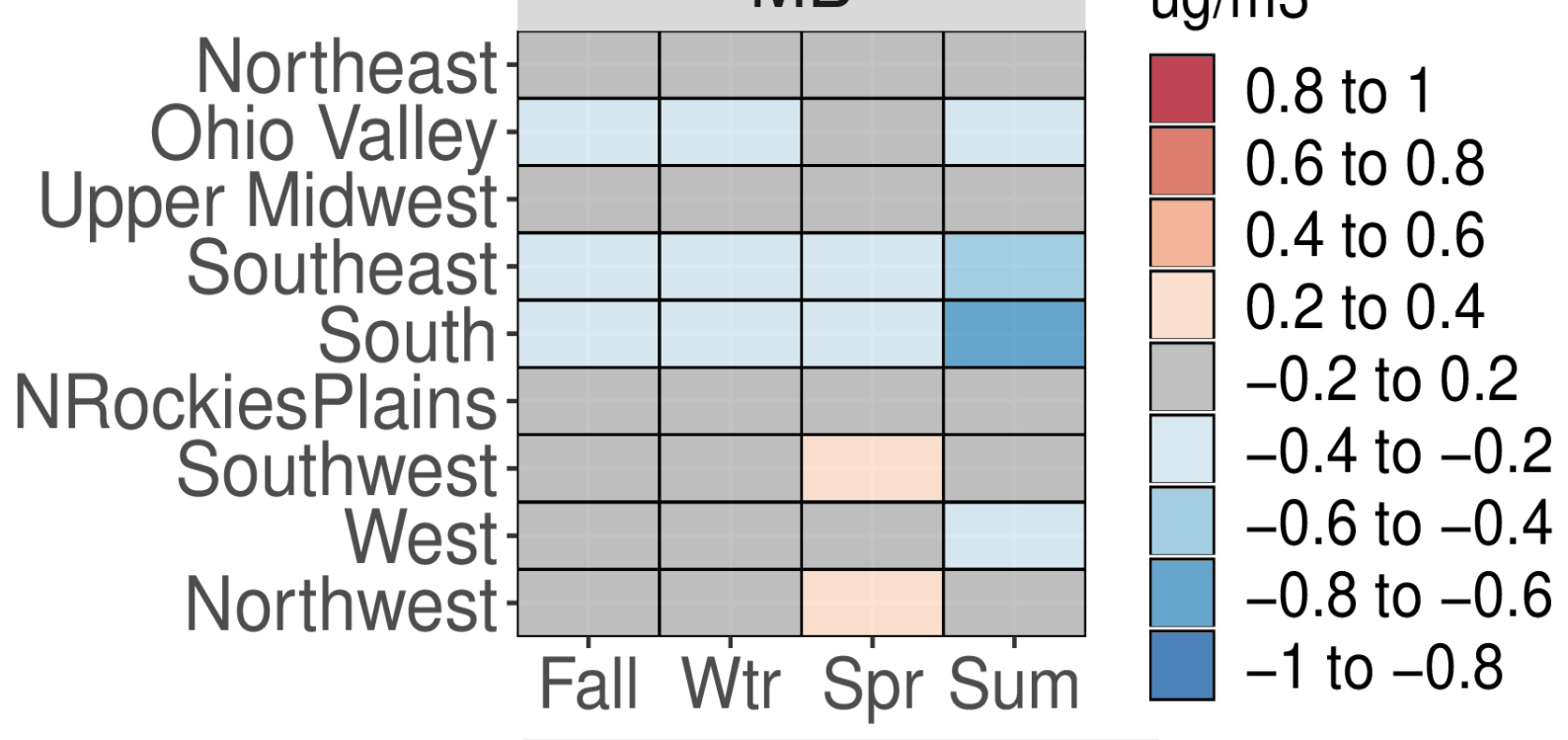

COR

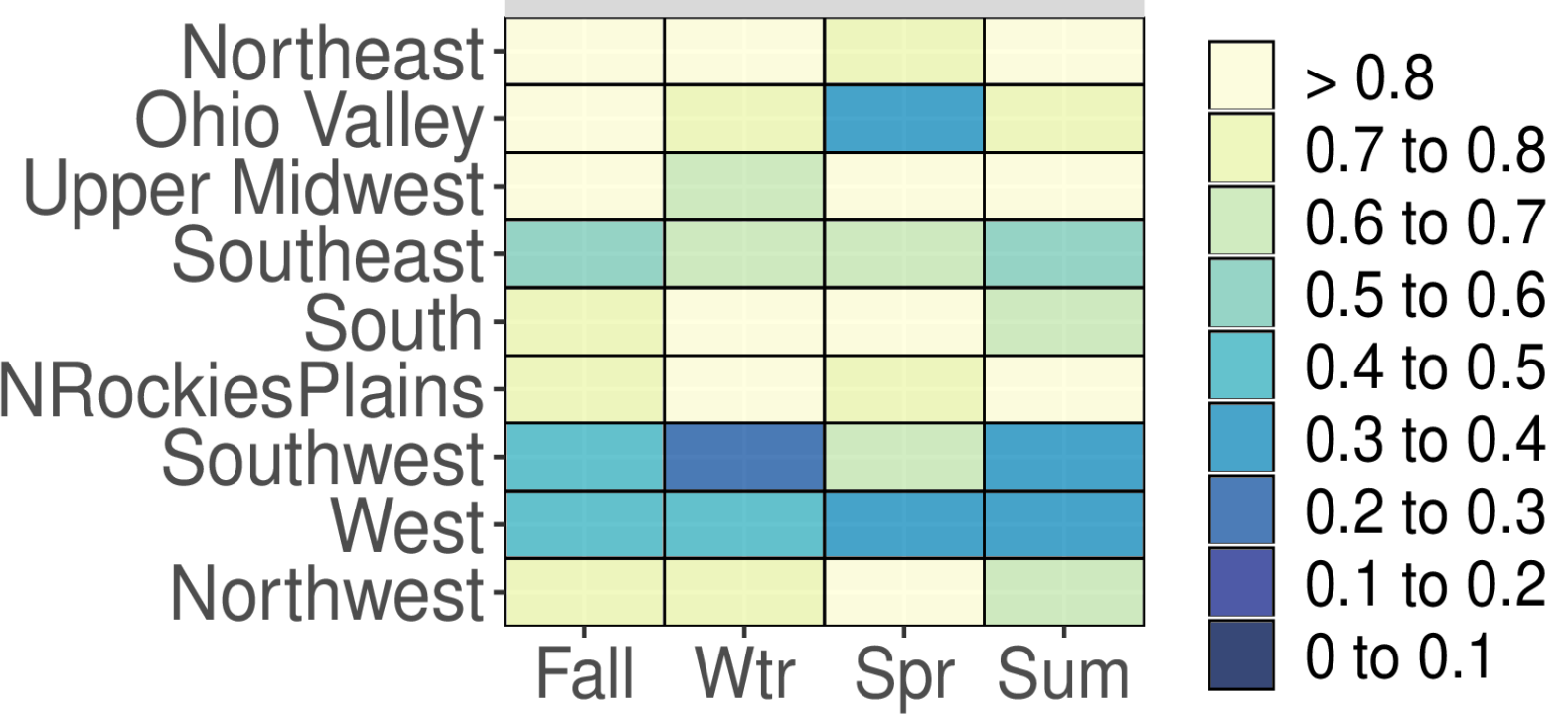

Figure S44. Categorical NMB (\%), MB $\left(\mu \mathrm{g} \mathrm{m}^{-3}\right)$, RMSE $\left(\mu \mathrm{g} \mathrm{m}^{-3}\right)$, and Pearson correlation values for $\mathrm{SO}_{4}{ }^{2-}$ for all CASTNet sites based on season and NOAA climate region for the CMAQ531_WRF411_M3Dry_BiDi simulation. 


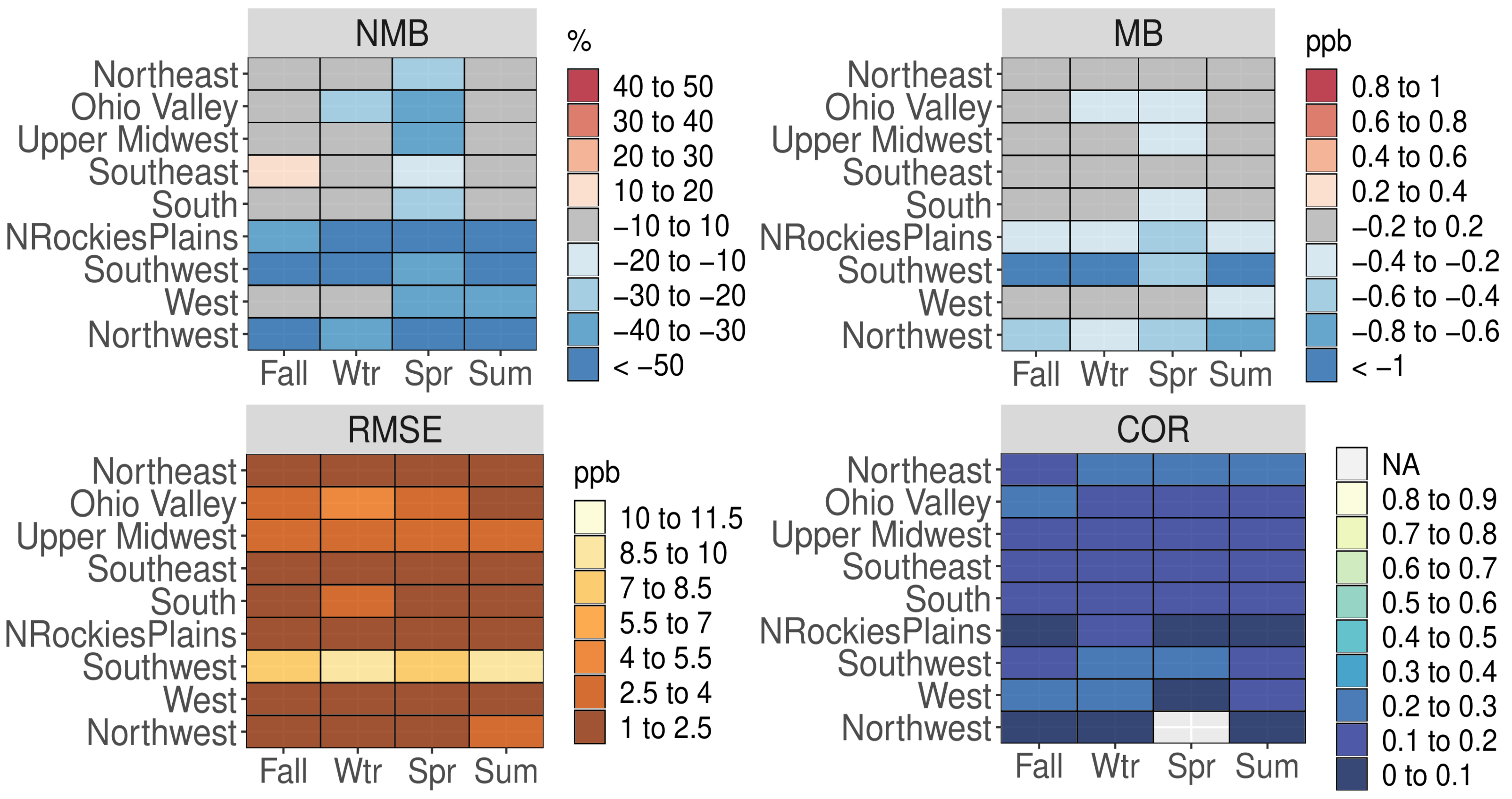

Figure S45. Categorical NMB (\%), MB (ppbv), RMSE (ppbv), and Pearson correlation values for $\mathrm{SO}_{2}$ (hourly) for all AQS sites based on season and NOAA climate region for the CMAQ521 simulation. 


\section{NMB}

Northeast

Ohio Valley

Upper Midwest

Southeast

South

NRockiesPlains

Southwest

West

Northwest-

\section{Fall Wtr Spr Sum}

\section{RMSE}

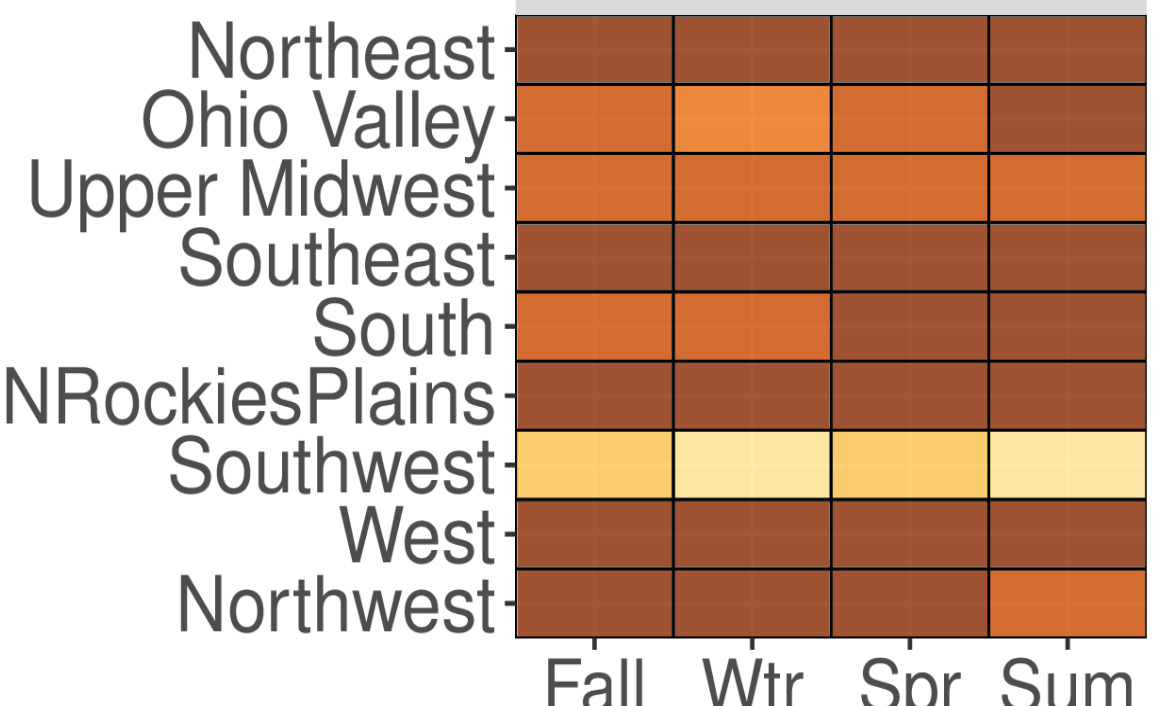

$\%$

\section{MB}

40 to 50

30 to 40

20 to 30

10 to 20

-10 to 10

-20 to -10

-30 to -20

-40 to -30

$<-50$ ppb

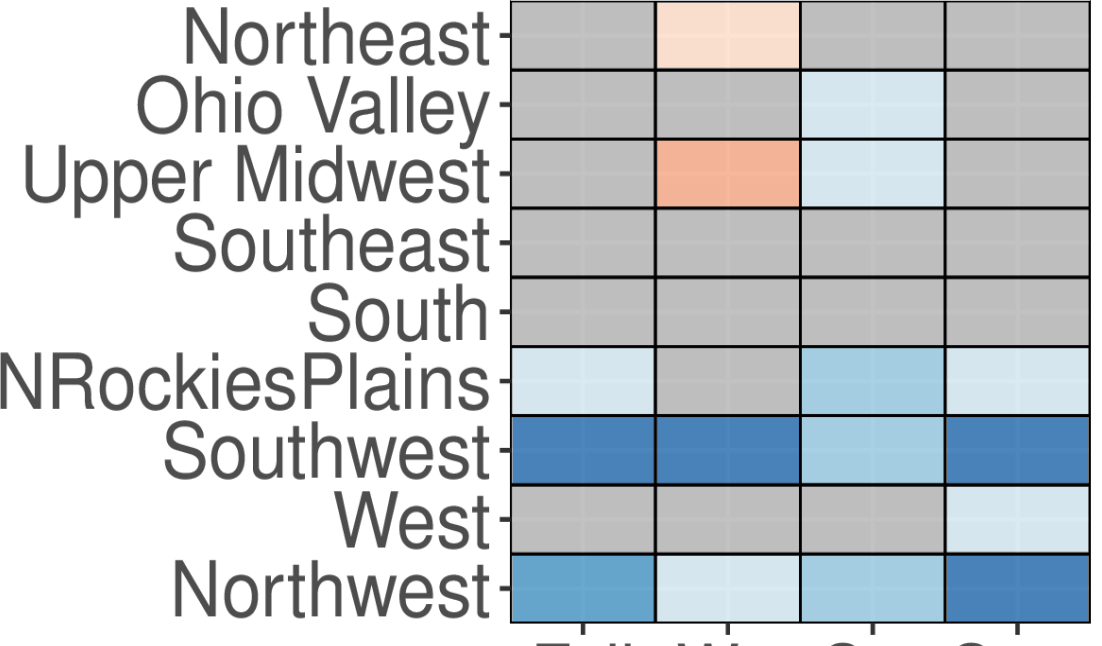

Fall Wtr Spr Sum

\section{COR}

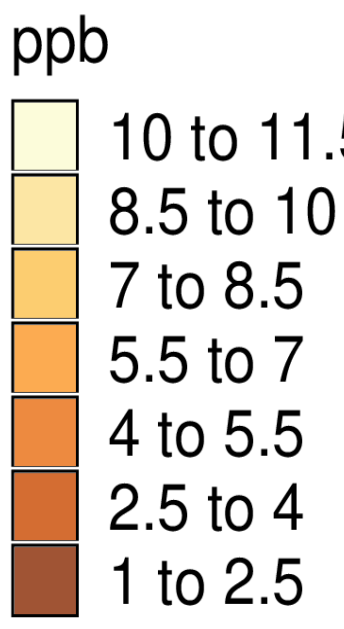

Northeast-

Ohio Valley

Upper Midwest

SoutheastSouth

NRockiesPlains

Southwest-

West

Northwest

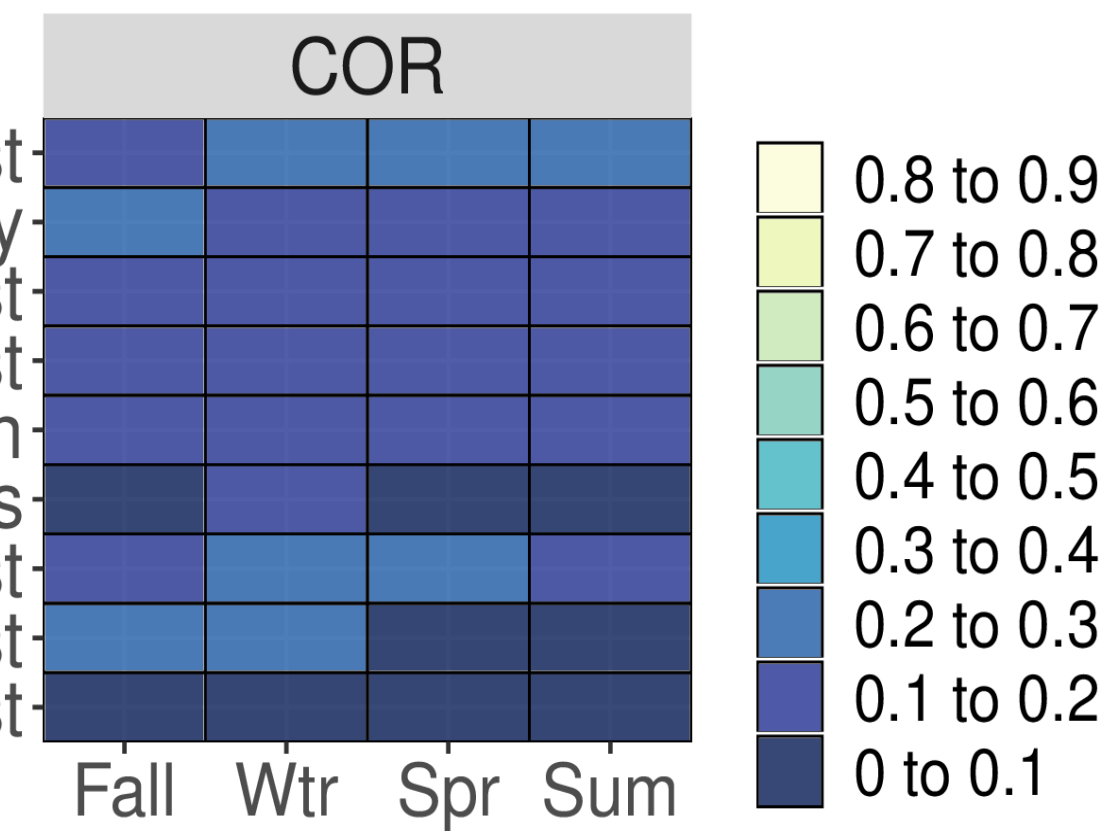

Figure S46. Categorical NMB (\%), MB (ppbv), RMSE (ppbv), and Pearson correlation values for $\mathrm{SO}_{2}$ (hourly) for all AQS sites based on season and NOAA climate region for the CMAQ531_WRF411_M3Dry_BiDi simulation. 


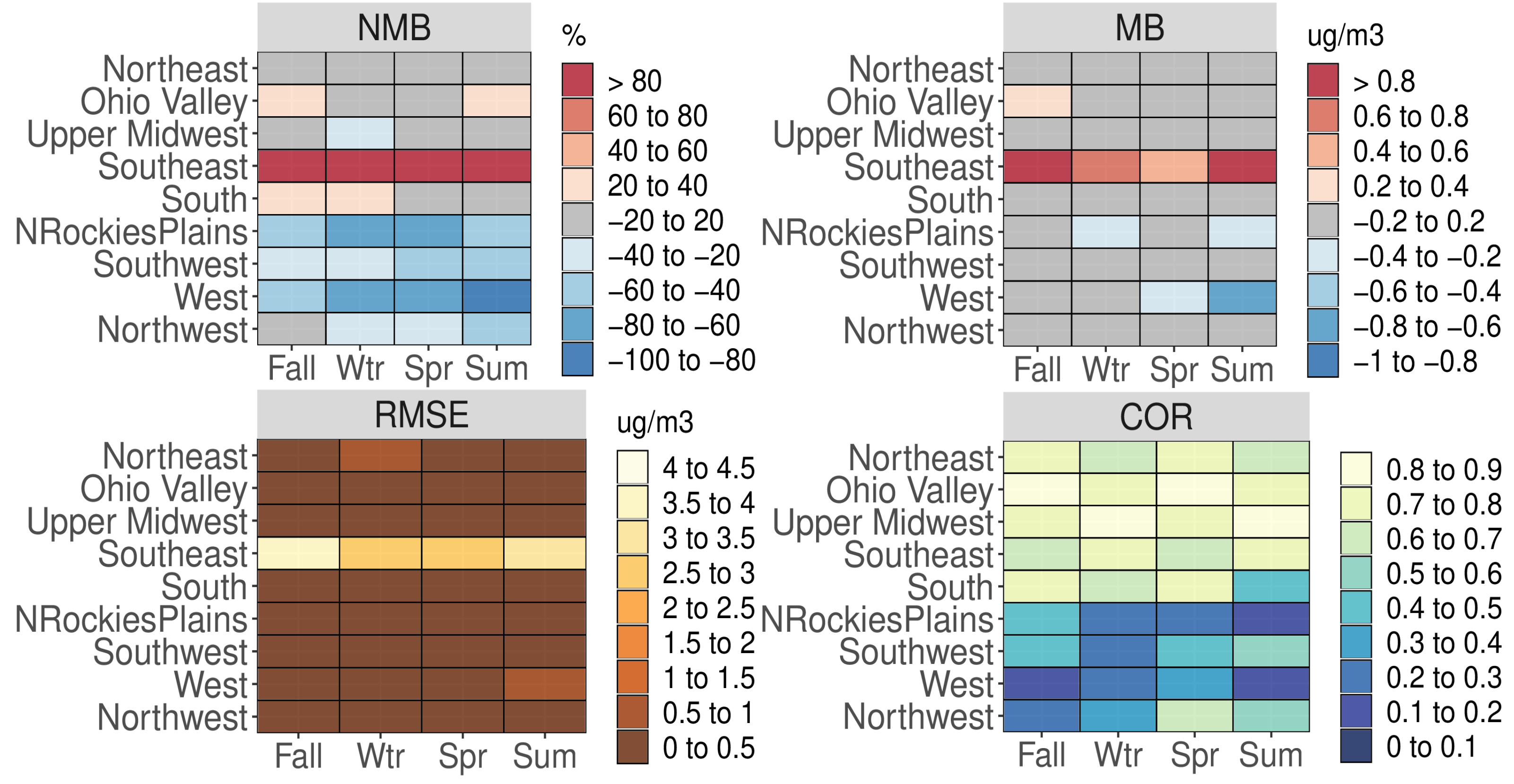

Figure S47. Categorical NMB (\%), MB $\left(\mu \mathrm{g} \mathrm{m}^{-3}\right)$, RMSE $\left(\mu \mathrm{g} \mathrm{m}^{-3}\right)$, and Pearson correlation values for $\mathrm{SO}_{2}$ (weekly) for all CASTNET sites based on season and NOAA climate region for the CMAQ521 simulation. 


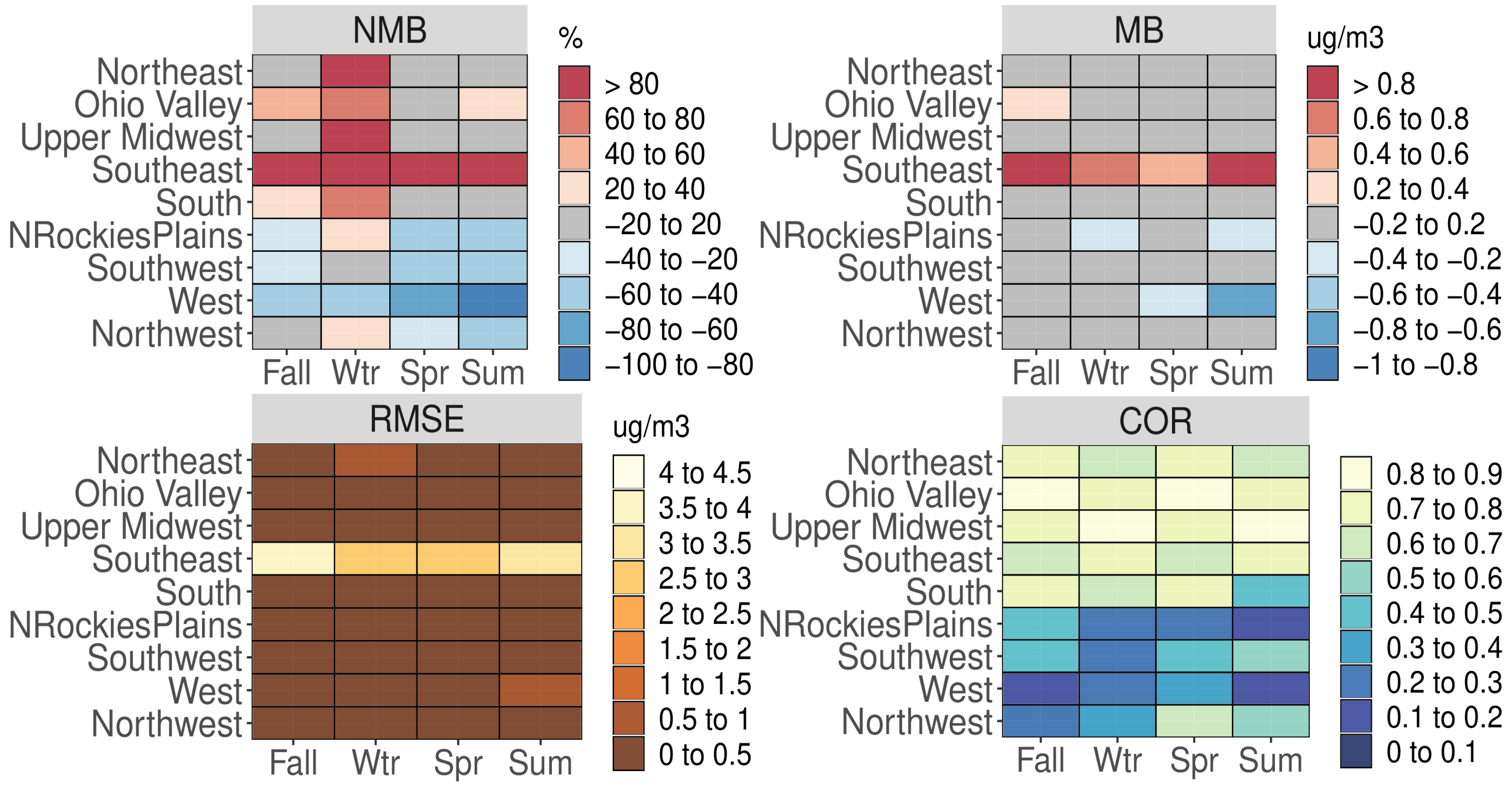

Figure S48. Categorical NMB (\%), MB $\left(\mu \mathrm{g} \mathrm{m}^{-3}\right)$, RMSE $\left(\mu \mathrm{g} \mathrm{m}^{-3}\right)$, and Pearson correlation values for $\mathrm{SO}_{2}$ (weekly) for all CASTNET sites based on season and NOAA climate region for the CMAQ531_WRF411_M3Dry_BiDi simulation. 


\section{NMB}



Fall Wtr Spr Sum

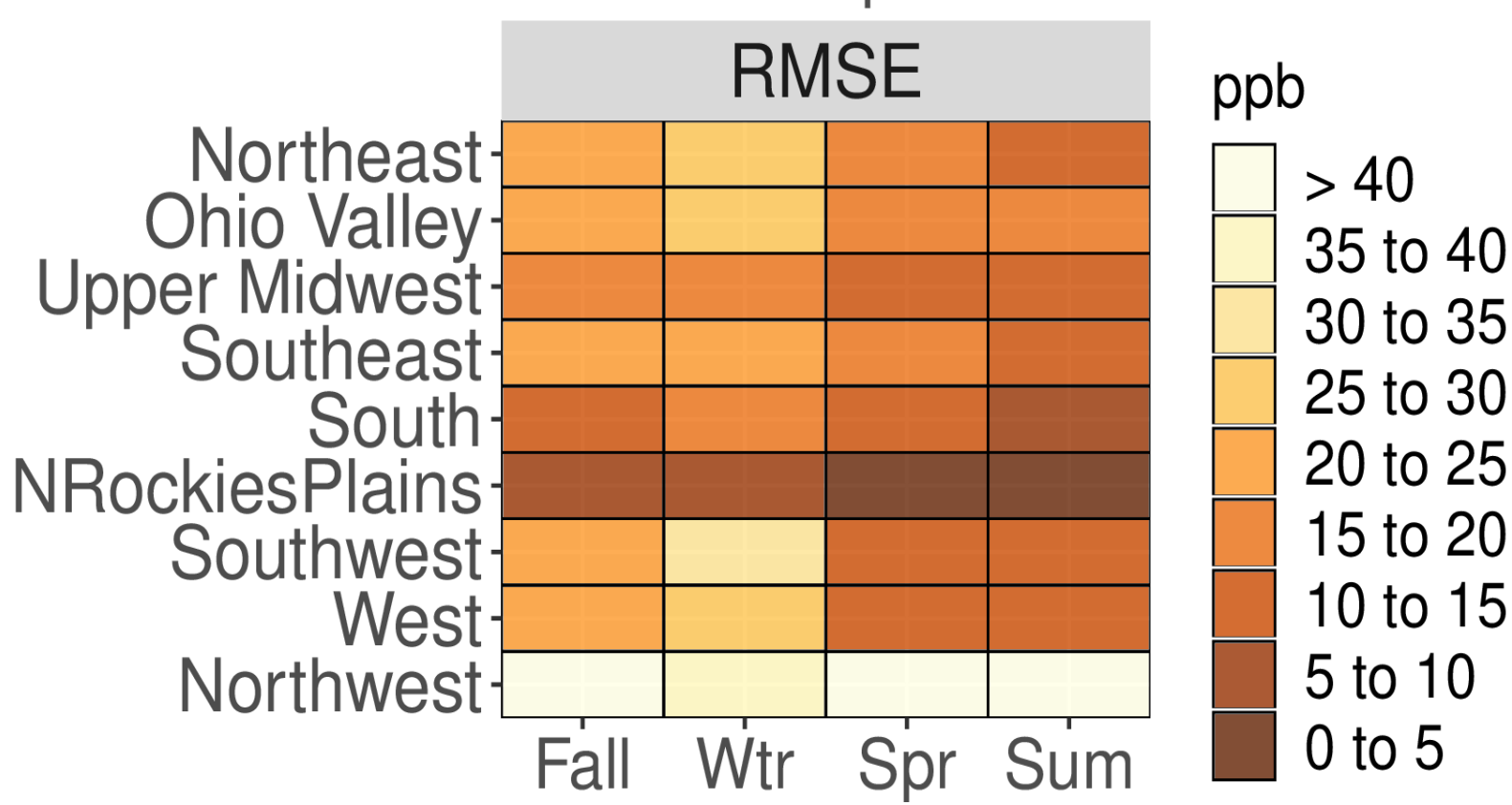

$\%$

40 to 50

30 to 40

20 to 30

10 to 20

-10 to 10

-20 to -10

-30 to -20

-40 to -30

$<-50$
NRockiesPlains

Southwest West

Northwest Ohio Valley Upper Midwest SoutheastSouth

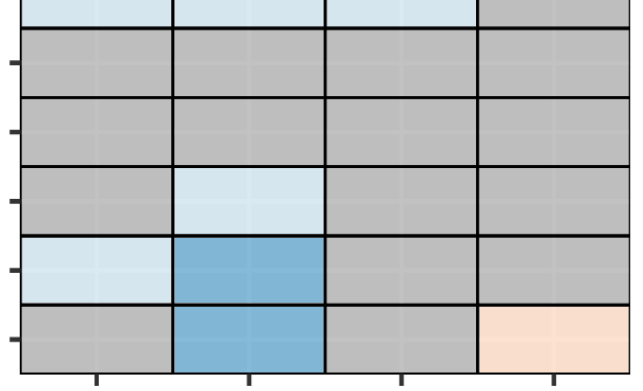

Fall Wtr Spr Sum

COR

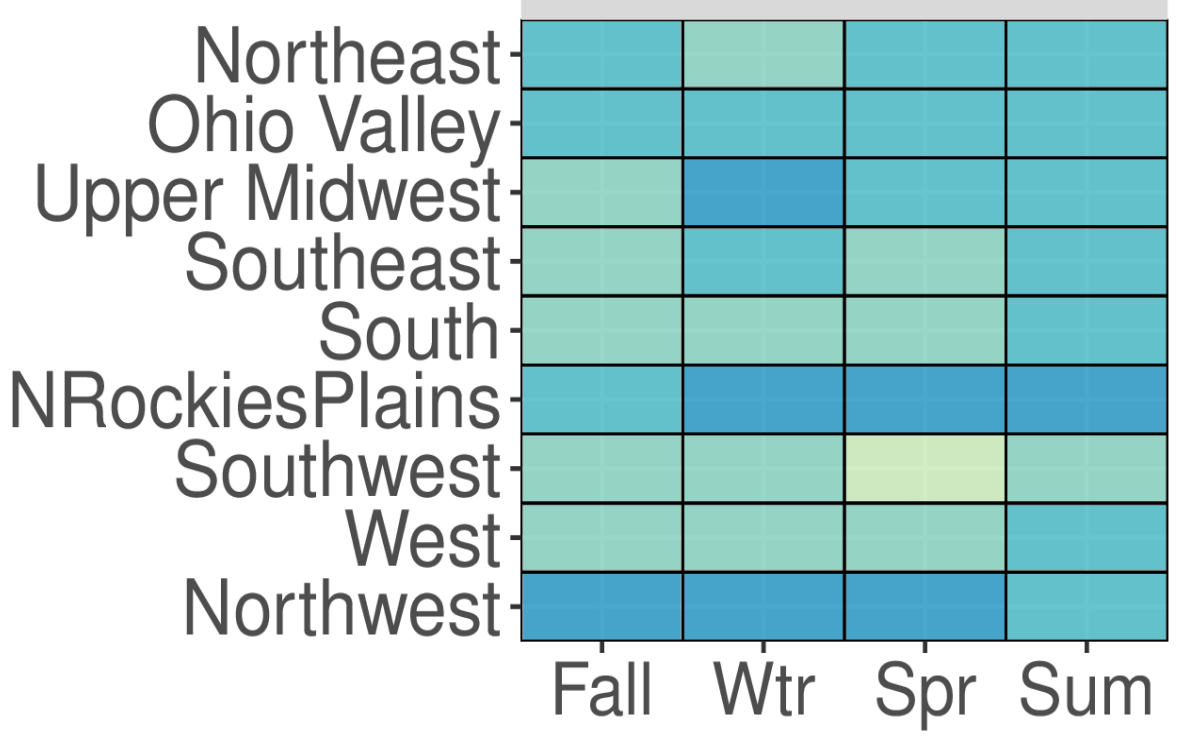

ppb

15 to 20

10 to 15

5 to 10

-5 to 5

-10 to -5

-15 to -10

-20 to -15

Figure S49. Categorical NMB (\%), MB (ppbv), RMSE (ppbv), and Pearson correlation values for $\mathrm{NO}_{\mathrm{X}}$ for all AQS sites based on season and NOAA climate region for the CMAQ521 simulation. 


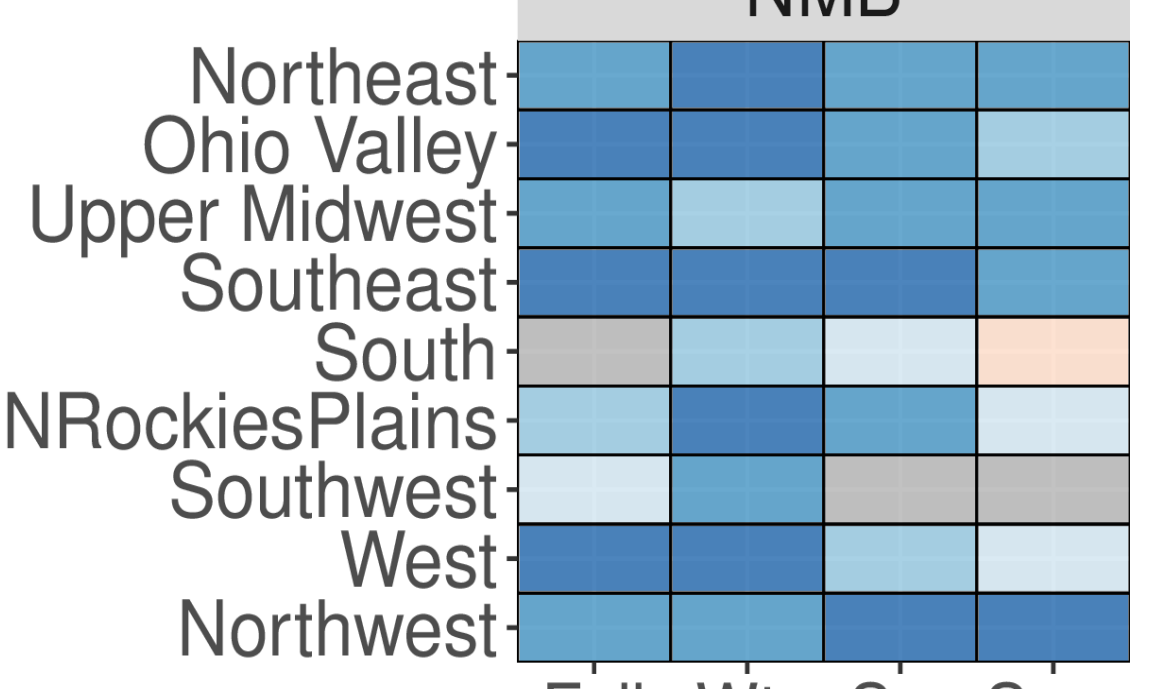

Fall Wtr Spr Sum

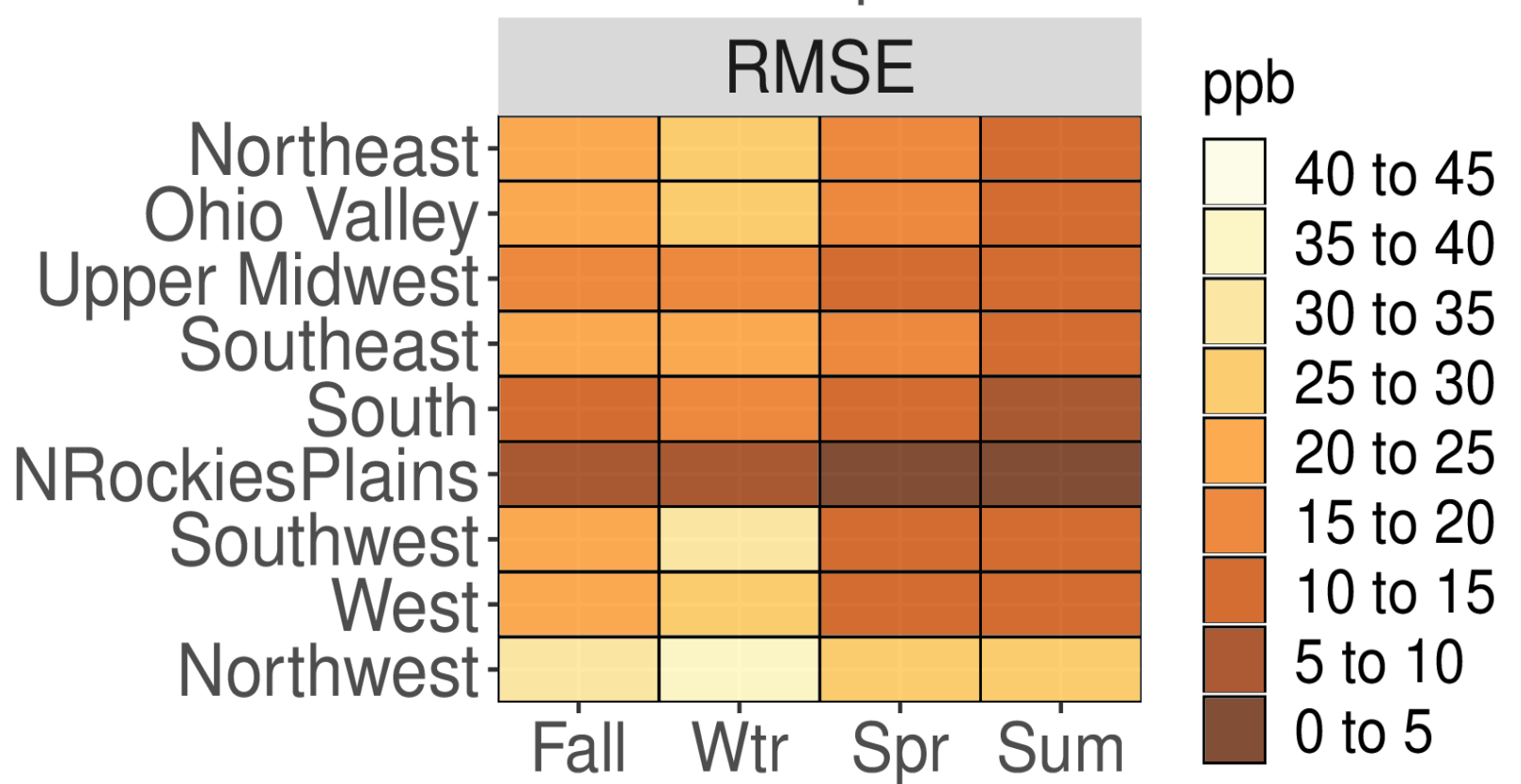

MB

40 to 50

30 to 40

20 to 30

10 to 20

-10 to 10

-20 to -10

-30 to -20

-40 to -30

$<-50$

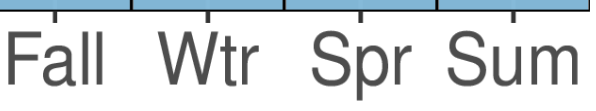

NRockiesPlains

Southwest

West

Northwest

Northeas
Ohio Valley

Upper Midwest

Southeast

South

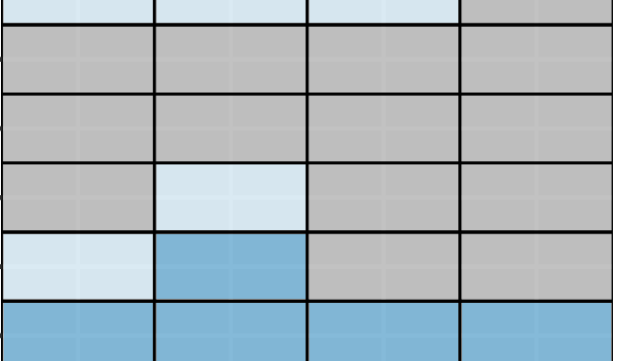

COR

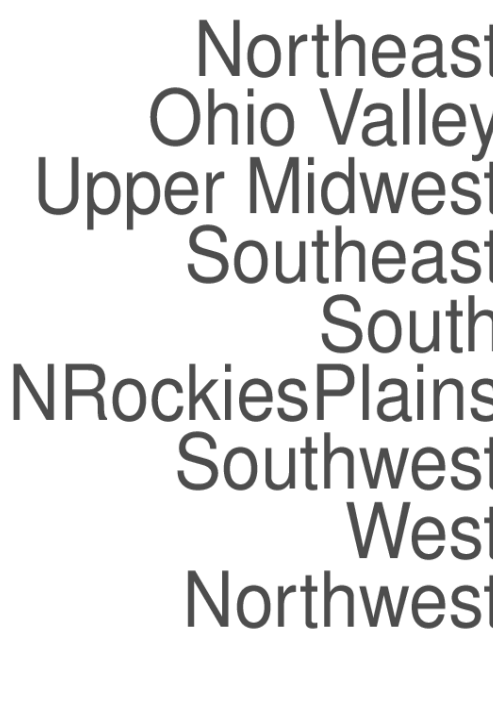

Figure S50. Categorical NMB (\%), MB (ppbv), RMSE (ppbv), and Pearson correlation values for $\mathrm{NO}_{\mathrm{X}}$ for all AQS sites based on season and NOAA climate region for the CMAQ531_WRF411_M3Dry_BiDi simulation. 


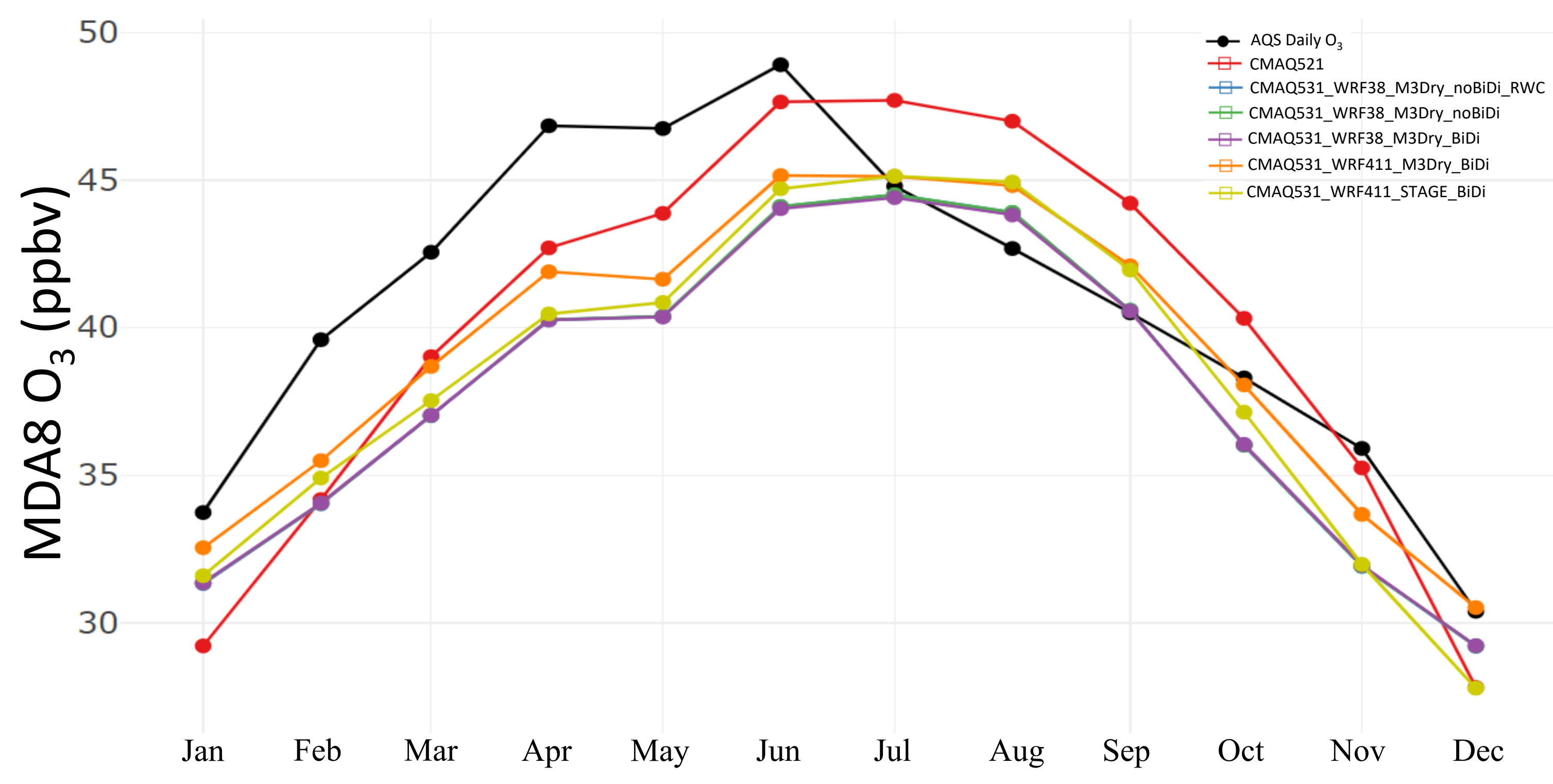

Figure S51. Time series of monthly average MDA8 $\mathrm{O}_{3}$ mixing ratio (ppbv) for all AQS sites (black), CMAQ521 (red),

CMAQ531_WRF38_M3Dry_noBiDi_RWC (blue), CMAQ531_WRF38_M3Dry_noBiDi (green), CMAQ531_WRF38_M3Dry_BiDi (purple), CMAQ531_WRF411_M3Dry_BiDi (orange), and CMAQ531_WRF411_STAGE_BiDi (yellow). 


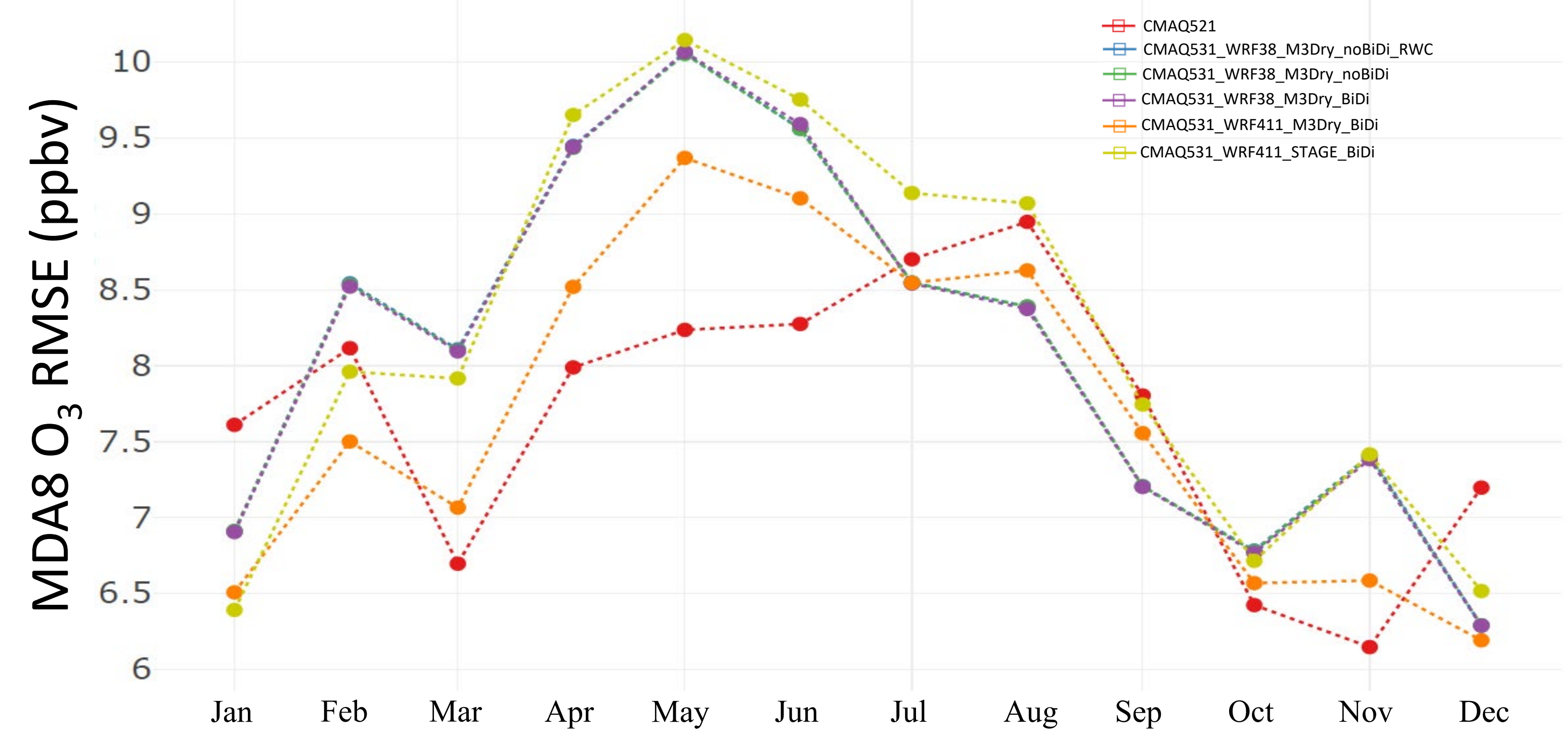

Figure S52. Time series of monthly average MDA8 $\mathrm{O}_{3}$ RMSE (ppbv) for all AQS sites for CMAQ521 (red), CMAQ531_WRF38_M3Dry_noBiDi_RWC (blue), CMAQ531_WRF38_M3Dry_noBiDi (green), CMAQ531_WRF38_M3Dry_BiDi (purple), CMAQ531_WRF411_M3Dry_BiDi (orange), and CMAQ531_WRF411_STAGE_BiDi (yellow). 


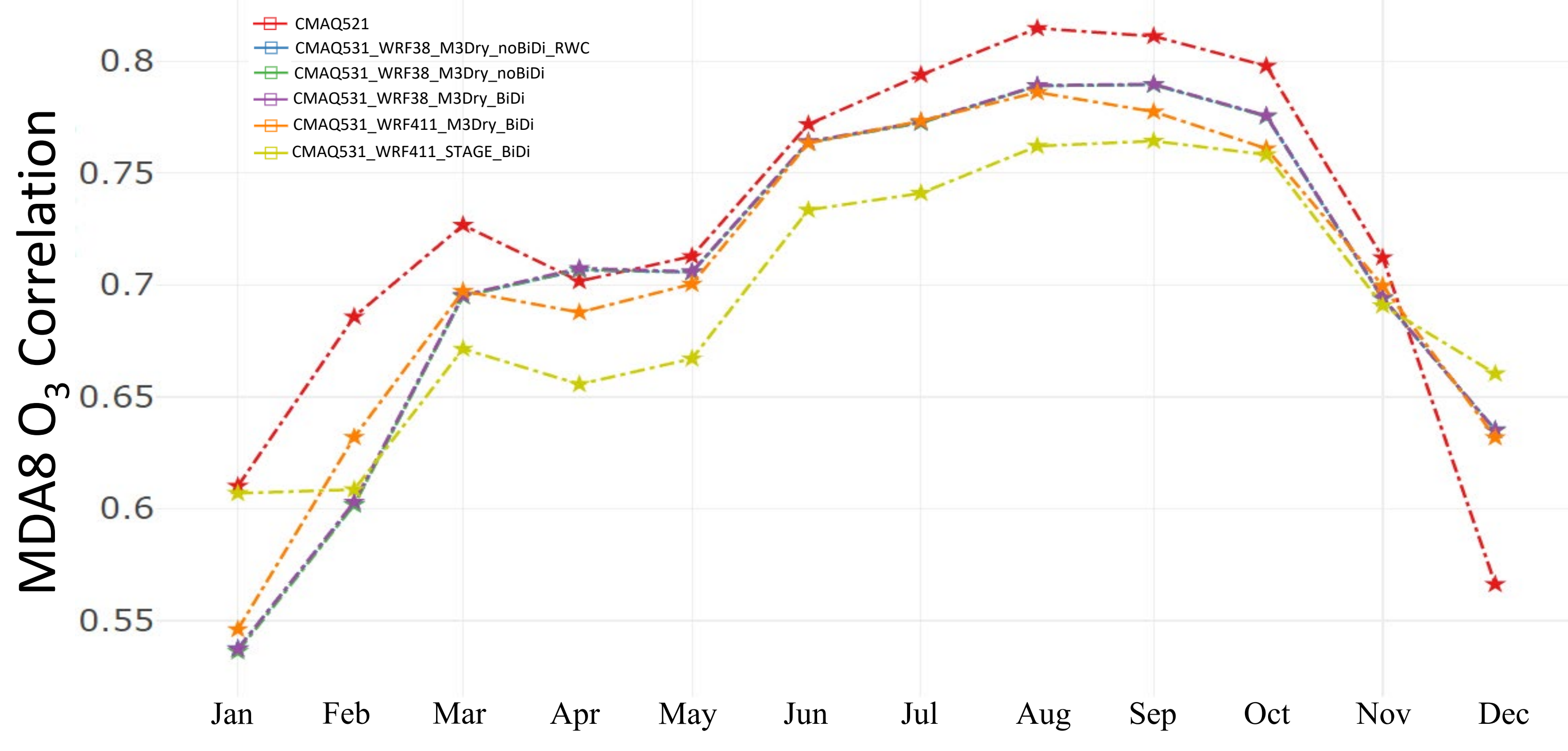

Figure S53. Time series of monthly average MDA8 $\mathrm{O}_{3}$ Pearson correlation for all AQS sites for CMAQ521 (red),

CMAQ531_WRF38_M3Dry_noBiDi_RWC (blue), CMAQ531_WRF38_M3Dry_noBiDi (green), CMAQ531_WRF38_M3Dry_BiDi (purple), CMAQ531_WRF411_M3Dry_BiDi (orange), and CMAQ531_WRF411_STAGE_BiDi (yellow). 


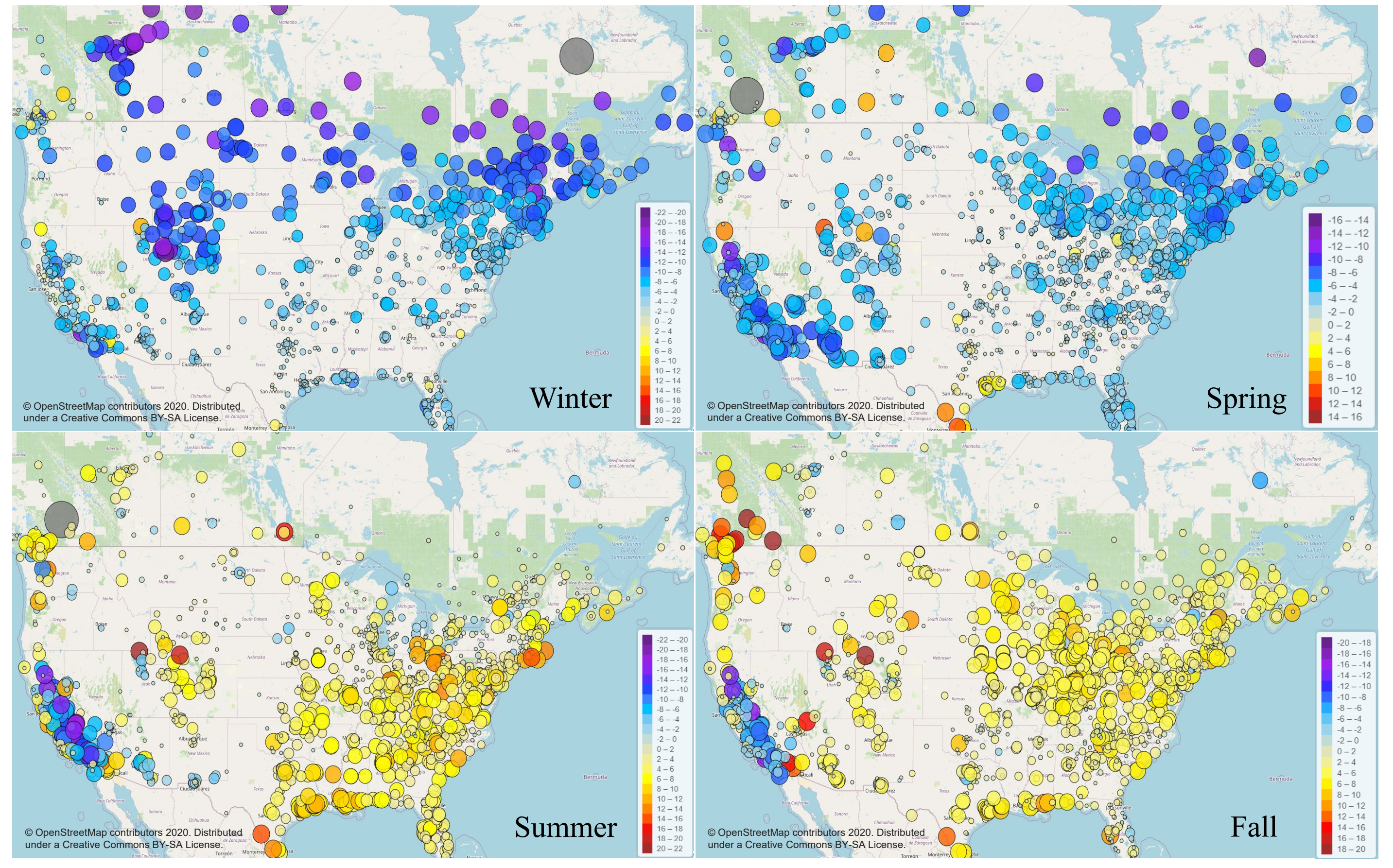

Figure S54. Seasonal average MDA8 $\mathrm{O}_{3}$ bias (ppbv) for AQS and NAPS sites for the CMAQ521 simulation. 


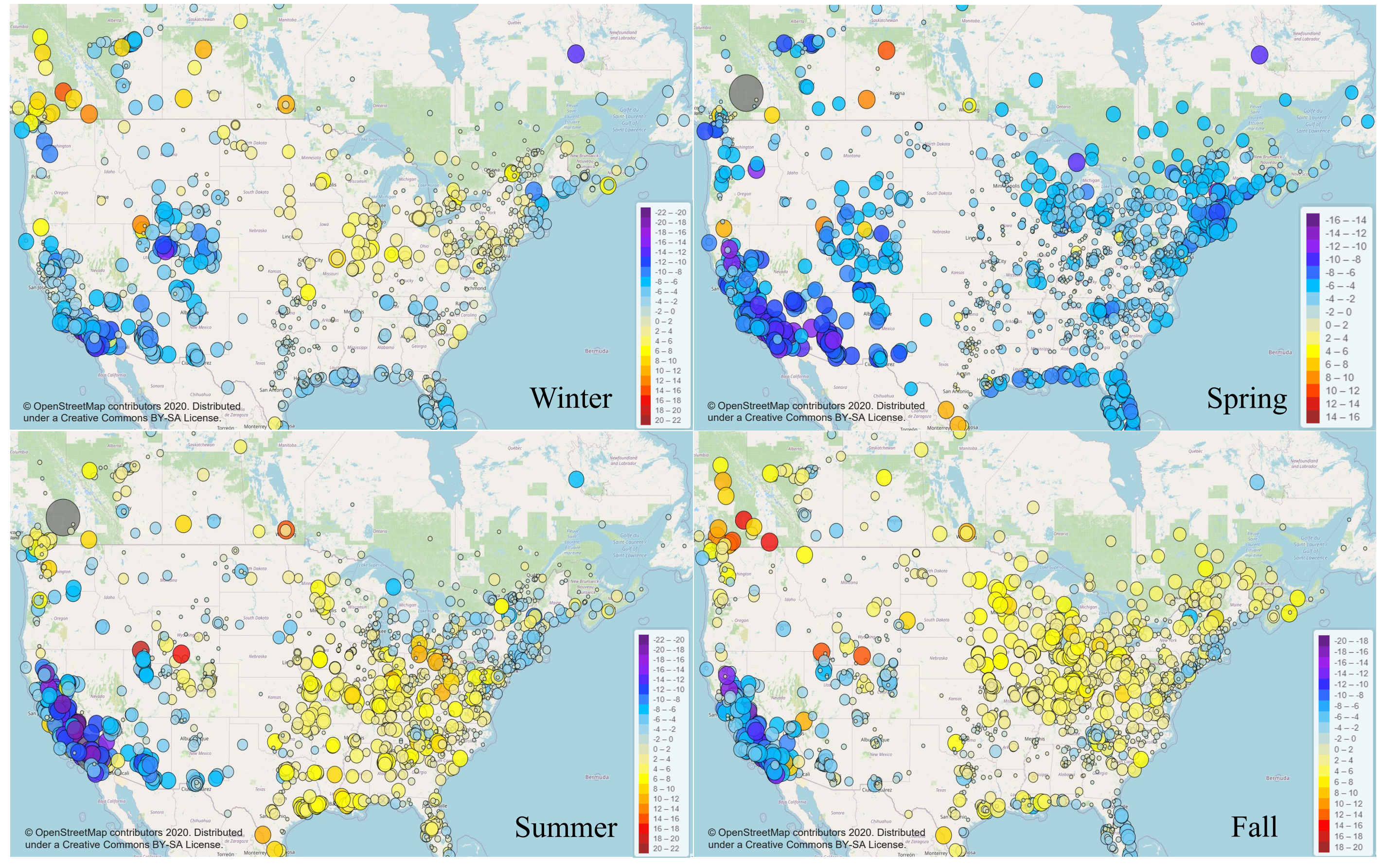

Figure S55. Seasonal average MDA8 $\mathrm{O}_{3}$ bias (ppbv) for AQS and NAPS sites for the CMAQ531_WRF411_M3Dry_BiDi simulation. 


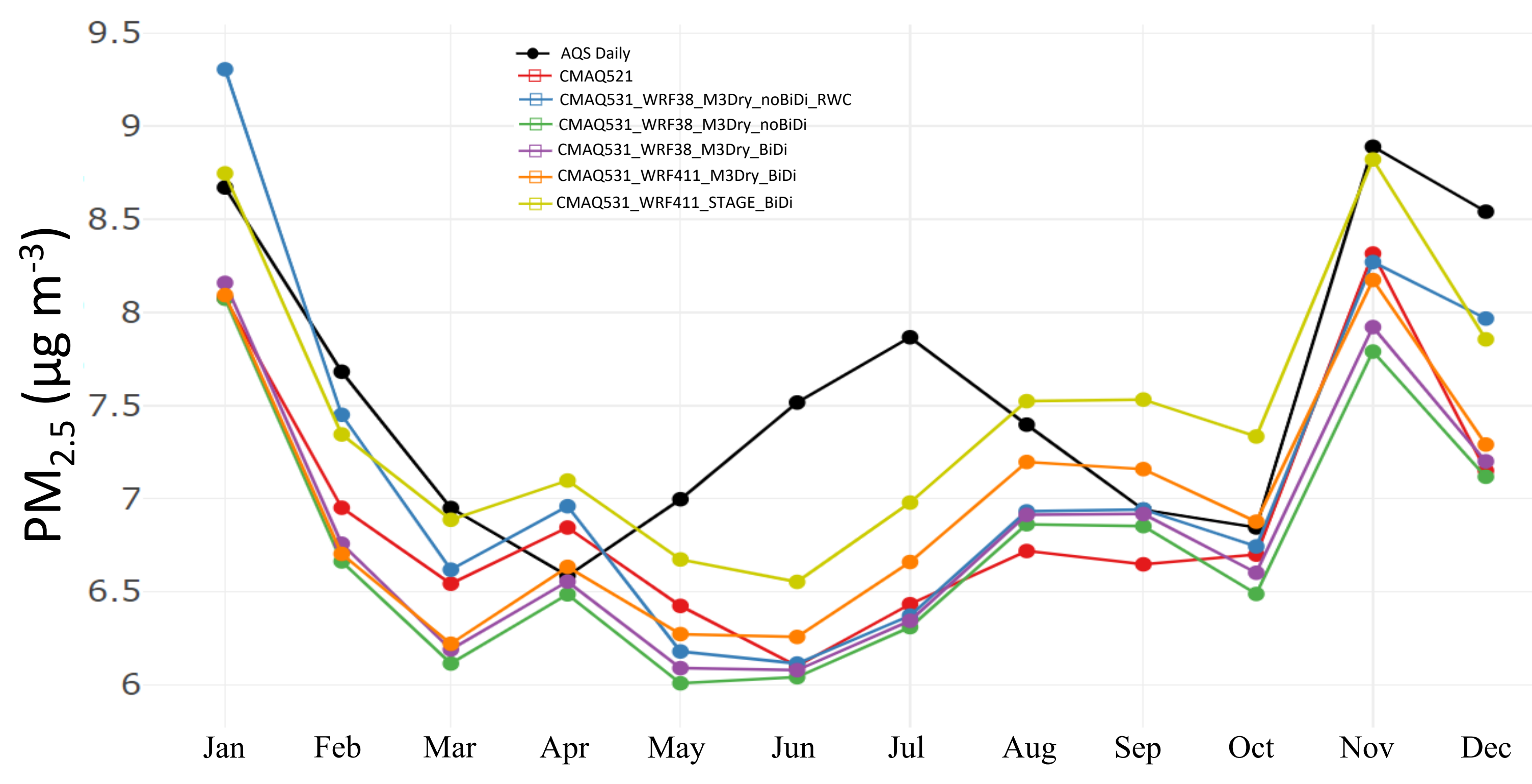

Figure S56. Time series of monthly average $\mathrm{PM}_{2.5}\left(\mu \mathrm{g} \mathrm{m}^{-3}\right)$ for all AQS sites (black), CMAQ521 (red), CMAQ531_WRF38_M3Dry_noBiDi_RWC (blue), CMAQ531_WRF38_M3Dry_noBiDi (green), CMAQ531_WRF38_M3Dry_BiDi (purple), CMAQ531_WRF411_M3Dry_BiDi (orange), and CMAQ531_WRF411_STAGE_BiDi (yellow). 


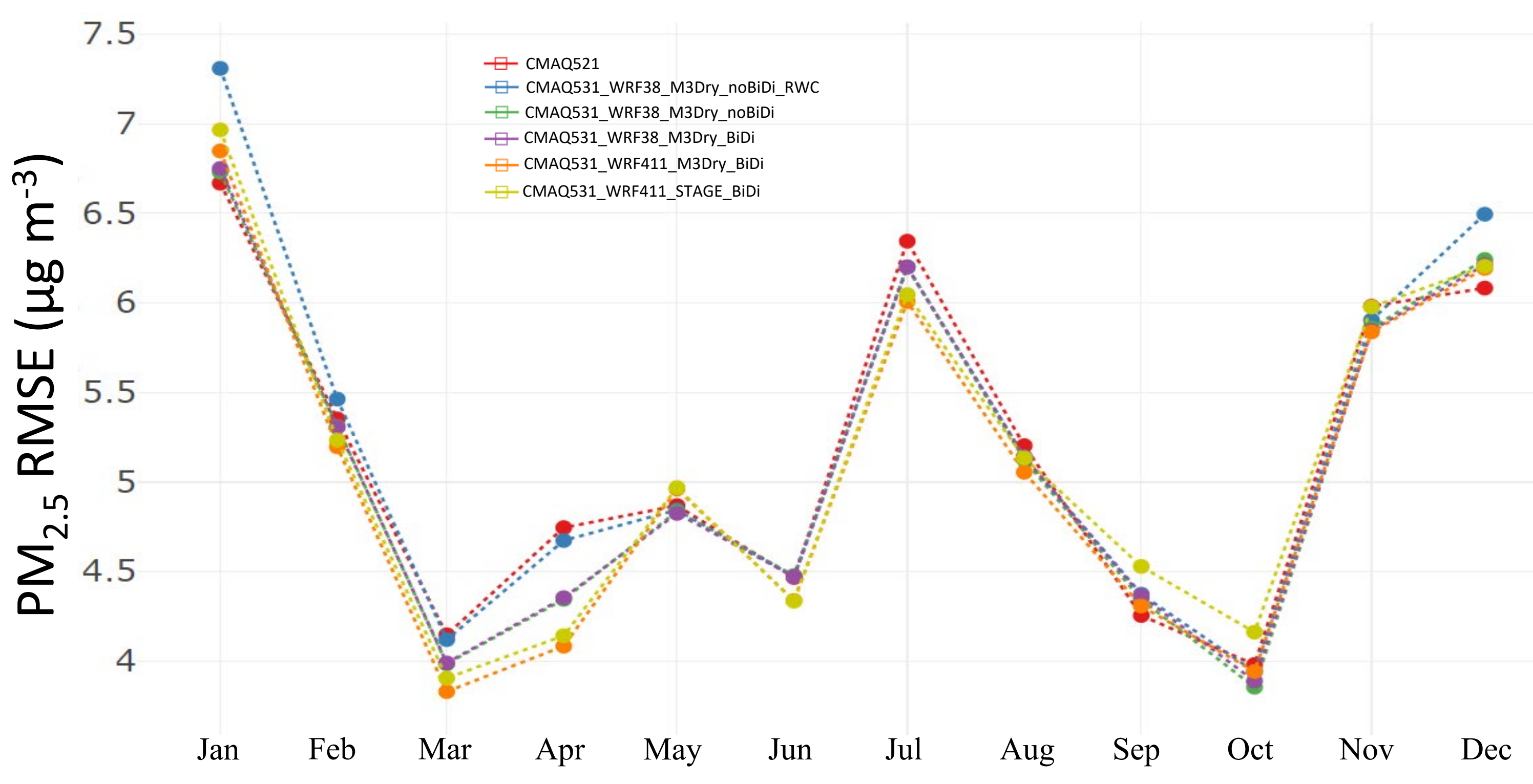

Figure S57. Time series of monthly average $\mathrm{PM}_{2.5}$ RMSE $\left(\mu \mathrm{g} \mathrm{m}^{-3}\right.$ ) for all AQS sites for CMAQ521 (red), CMAQ531_WRF38_M3Dry_noBiDi_RWC (blue), CMAQ531_WRF38_M3Dry_noBiDi (green), CMAQ531_WRF38_M3Dry_BiDi (purple), CMAQ531_WRF411_M3Dry_BiDi (orange), and CMAQ531_WRF411_STAGE_BiDi (yellow). 


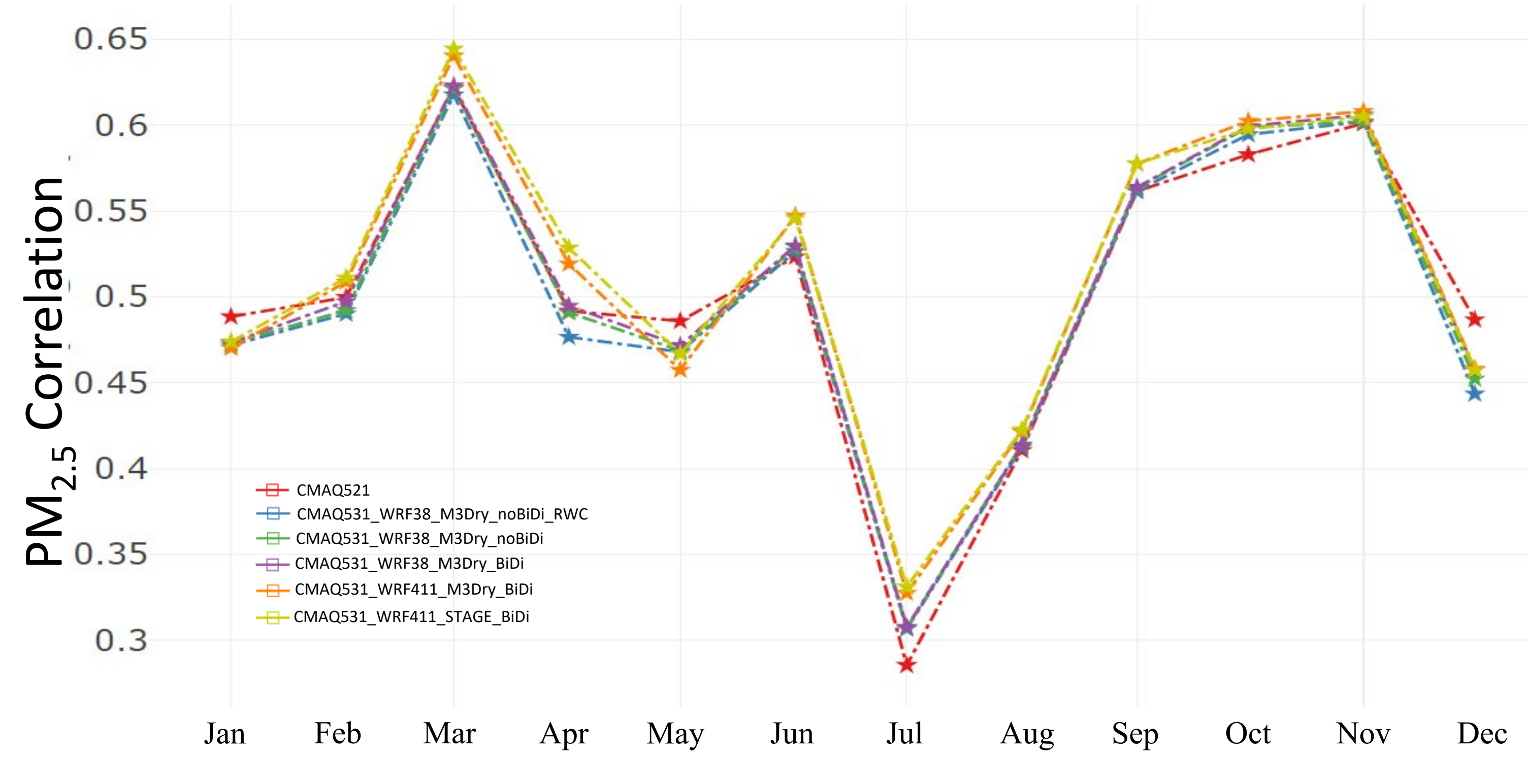

Figure S58. Time series of monthly average $\mathrm{PM}_{2.5}$ Pearson correlation for all AQS sites for CMAQ521 (red), CMAQ531_WRF38_M3Dry_noBiDi_RWC (blue), CMAQ531_WRF38_M3Dry_noBiDi (green), CMAQ531_WRF38_M3Dry_BiDi (purple), CMAQ531_WRF411_M3Dry_BiDi (orange), and CMAQ531_WRF411_STAGE_BiDi (yellow). 


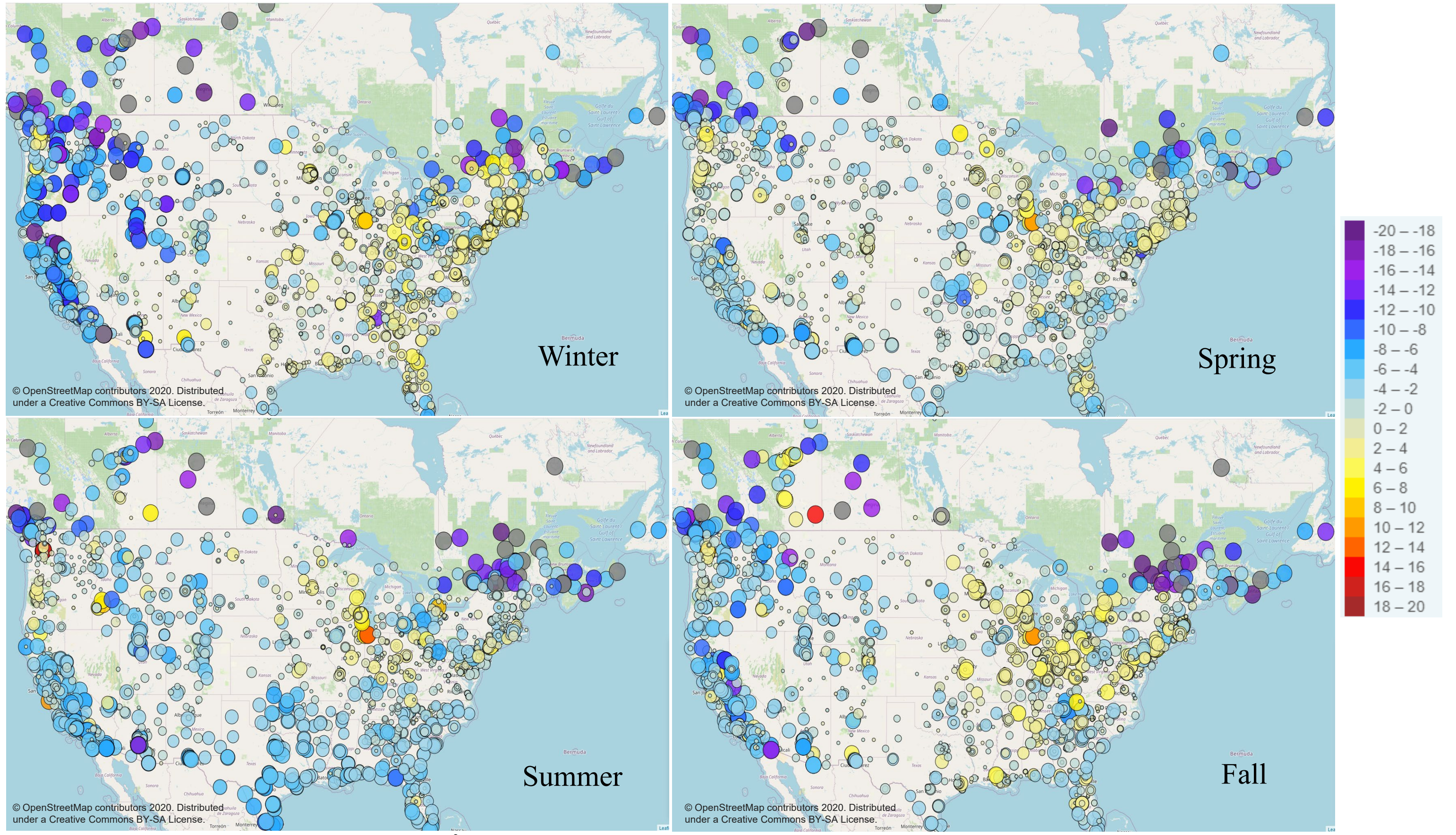

Figure S59. Seasonal average $\mathrm{PM}_{2.5}$ bias $\left(\mu \mathrm{g} \mathrm{m}^{-3}\right)$ for AQS and NAPS sites for the CMAQ521 simulation. The symbol size is commensurate with the absolute value of the bias. Gray symbols indicate values outside the color scale (i.e. outliers). 


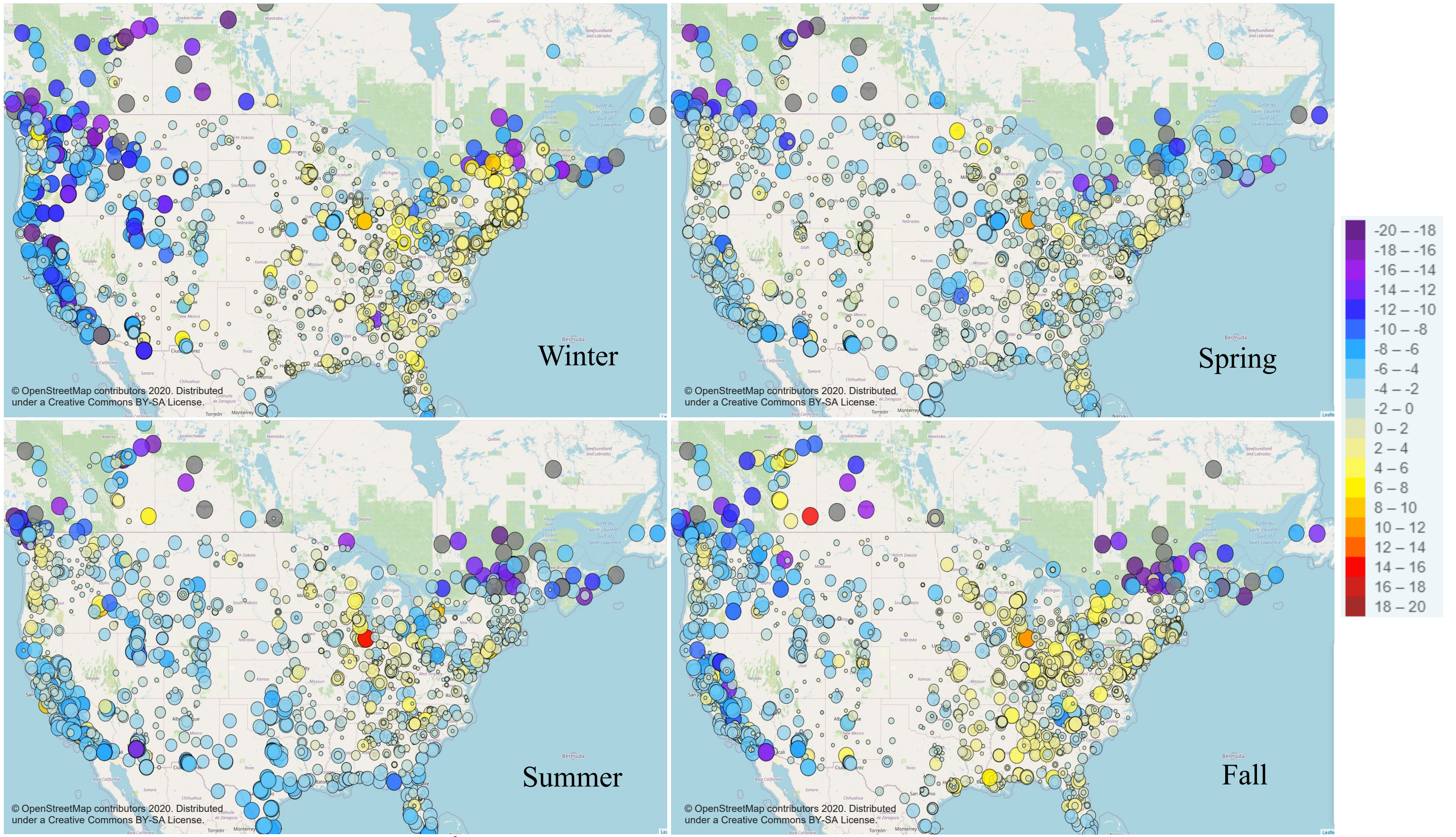

Figure S60. Seasonal average $\mathrm{PM}_{2.5}$ bias $\left(\mu \mathrm{g} \mathrm{m}^{-3}\right)$ for AQS and NAPS sites for the CMAQ531_WRF411_M3Dry_BiDi simulation. The symbol size is commensurate with the absolute value of the bias. Gray symbols indicate values outside the color scale (i.e. outliers). 
2016 WRFv411CMAQv531 vs. WRFv38CMAQv531 Seasonal Mean,VD_O 2016 WRFv411CMAQv531 vs. WRFv38CMAQv531 Seasonal Mean,O3
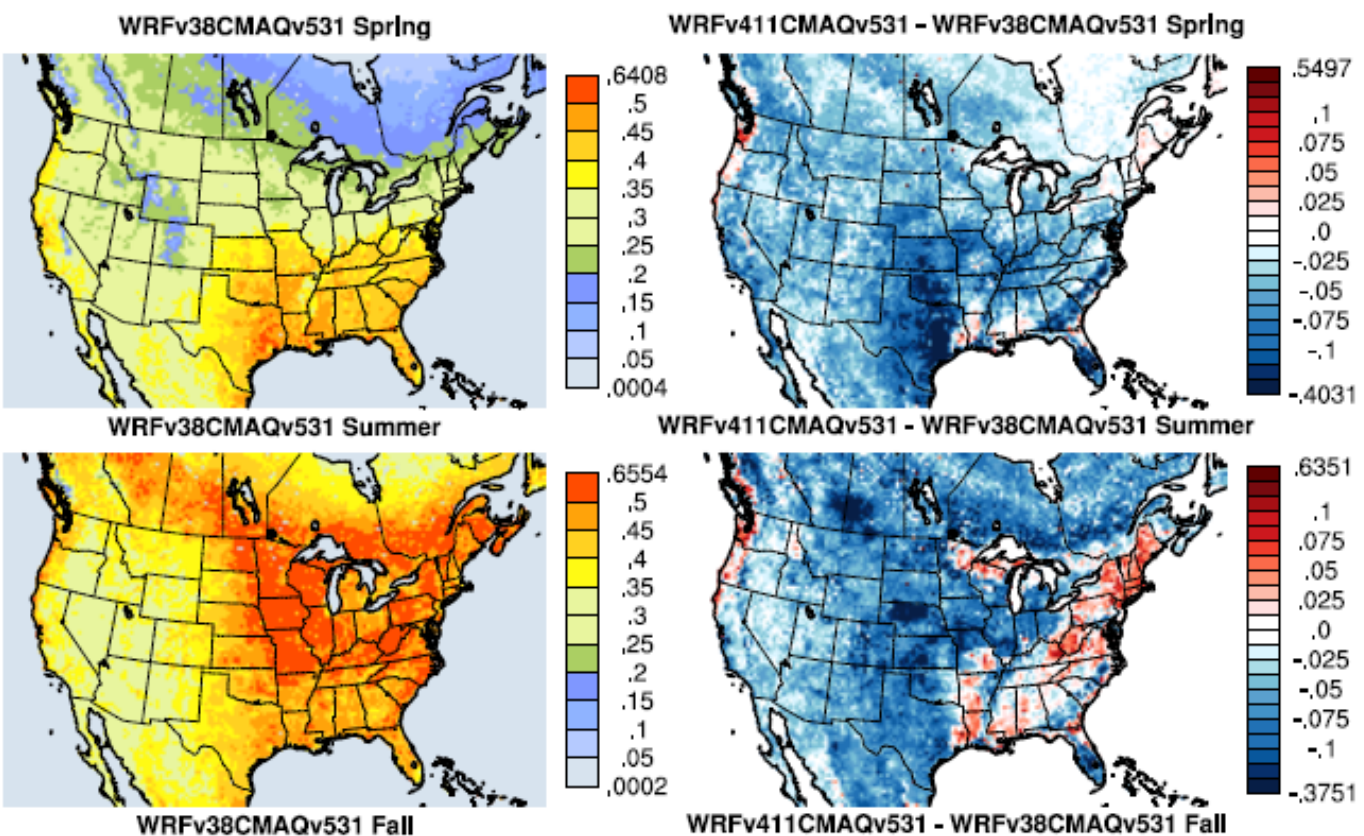

WRFv11CMAOv531- WRFv38CMAOV531 Summer
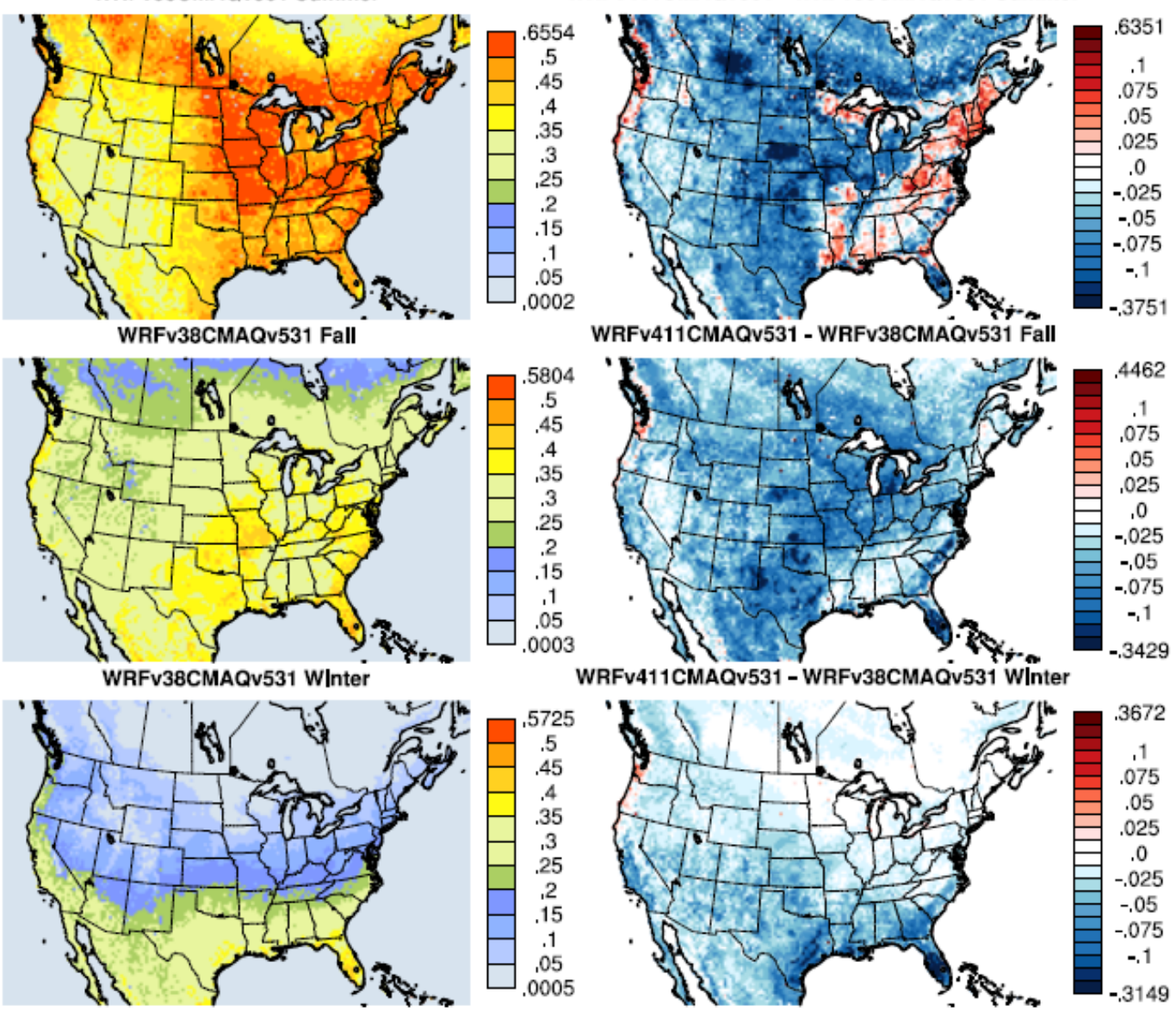

WRFv38CMAQv531 Sprlng

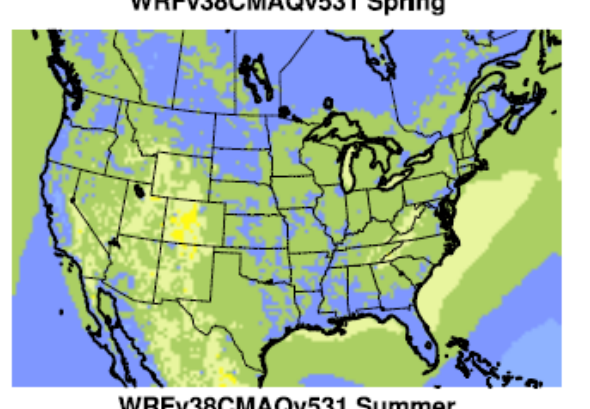

MAQv531 Summer

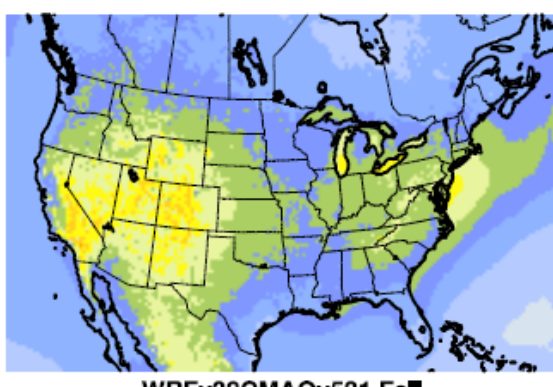

WRFv38CMAQv531 Fall
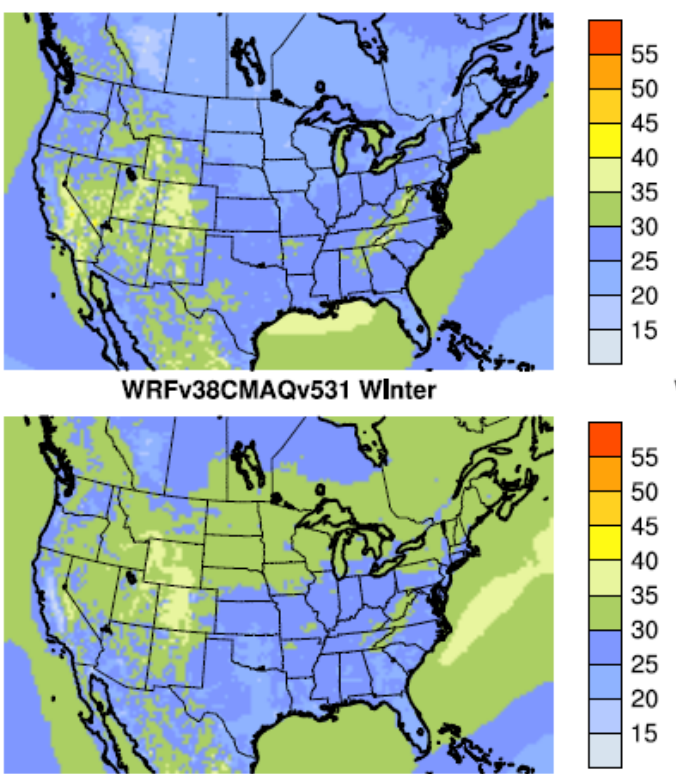

WRFv411CMAQv531 - WRFv38CMAQv531 Spring

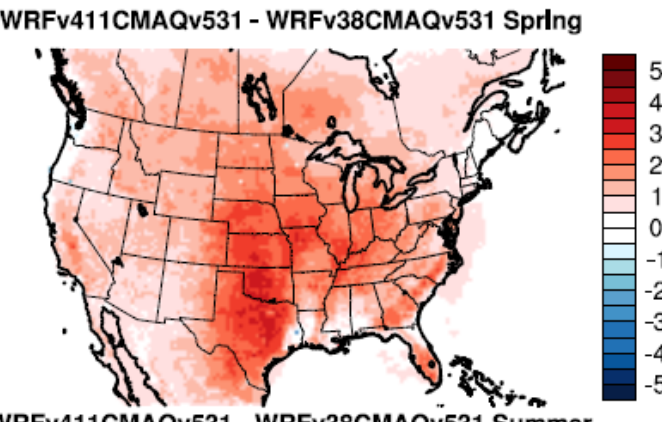

WRFv411CMAQv531 - WRFv38CMAQV531 Summer

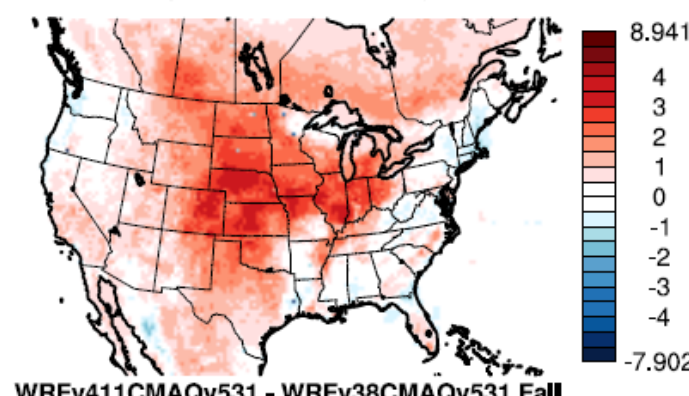

WRFv411CMAQv531 - WRFv38CMAQv531 Fall
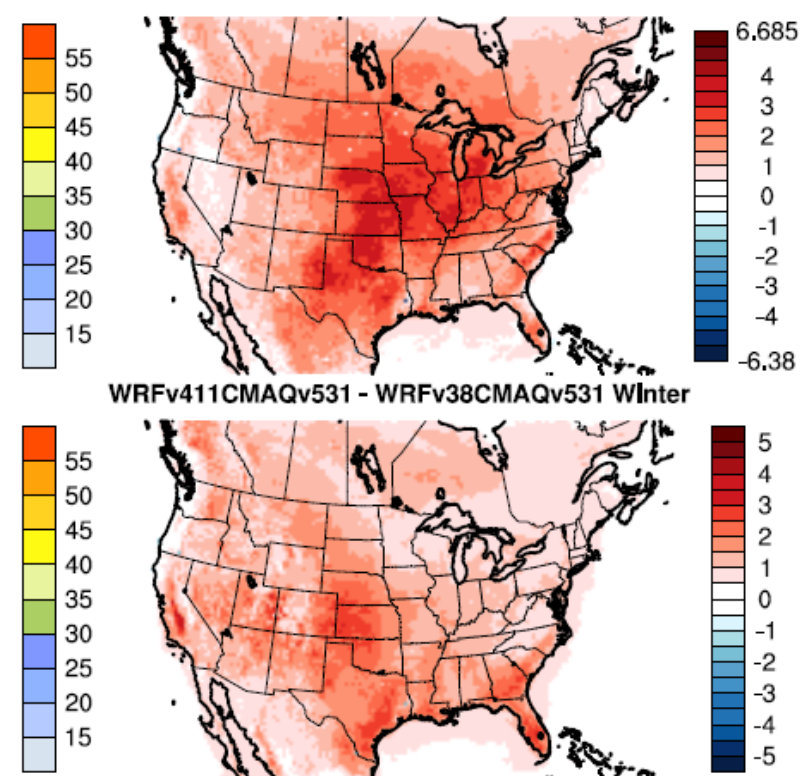

Figure S61. Seasonal $\mathrm{O}_{3}$ deposition velocity $\left(\mathrm{VD}_{-} \mathrm{O}_{3} ; \mathrm{cm} \mathrm{s}^{-1}\right.$; left) and $\mathrm{O}_{3}$ mixing ratio (ppbv; right) for the CMAQ531_WRF38_M3Dry_BiDi simulation along with the difference in VD_O $\mathrm{O}_{3}$ and mixing ratio between the CMAQ531_WRF38_M3Dry_Bidi and CMAQ531_WRF411_M3Dry_BiDi simulations (WRF411 - WRF38). 
2016 WRFv411CMAQv531 vs. WRFv38CMAQv531 Seasonal Mean,VMASSJ 2016 WRFv411CMAQv531 vs. WRFv38CMAQv531 Seasonal Mean,ATOTIJ

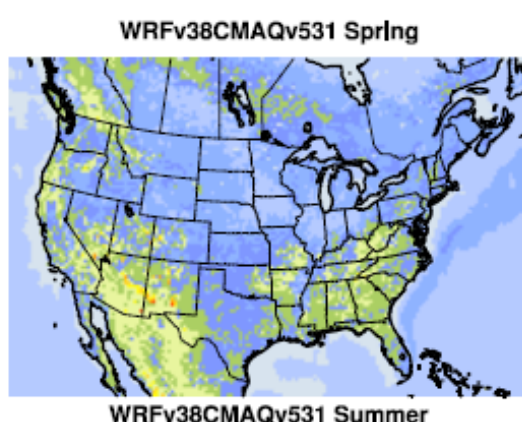

WRFv411CMAQv531 - WRFv38CMAQv531 Spring

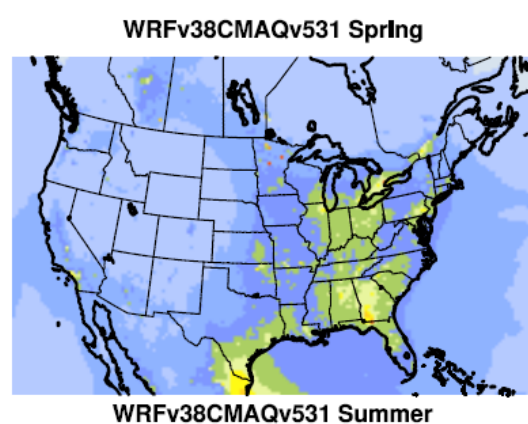

WRFv411CMAQv531 - WRFv38CMAQv531 Sprlng
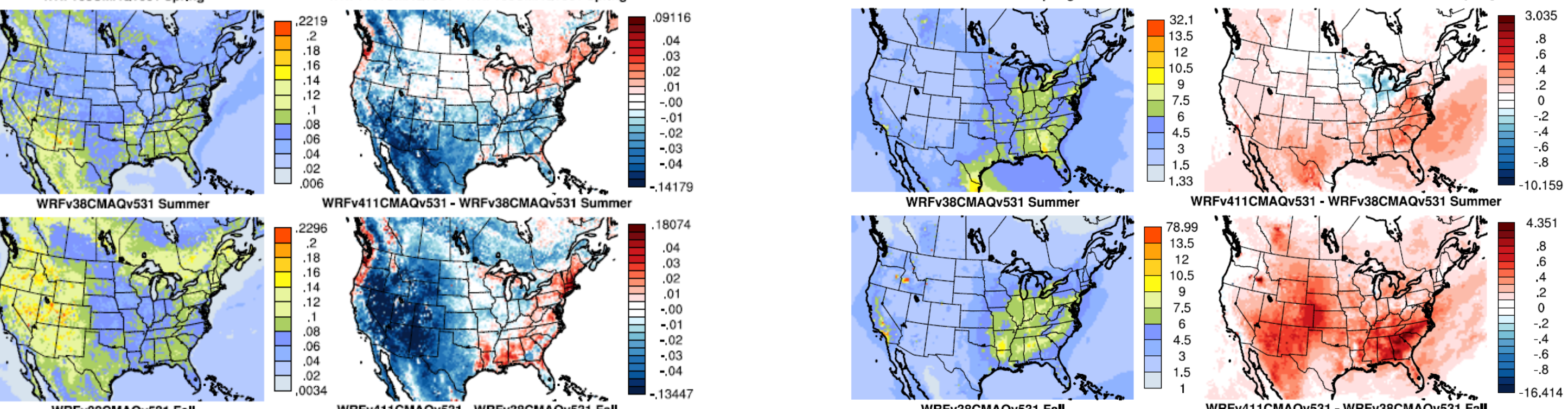

WRFV38CMAQv531 Fall
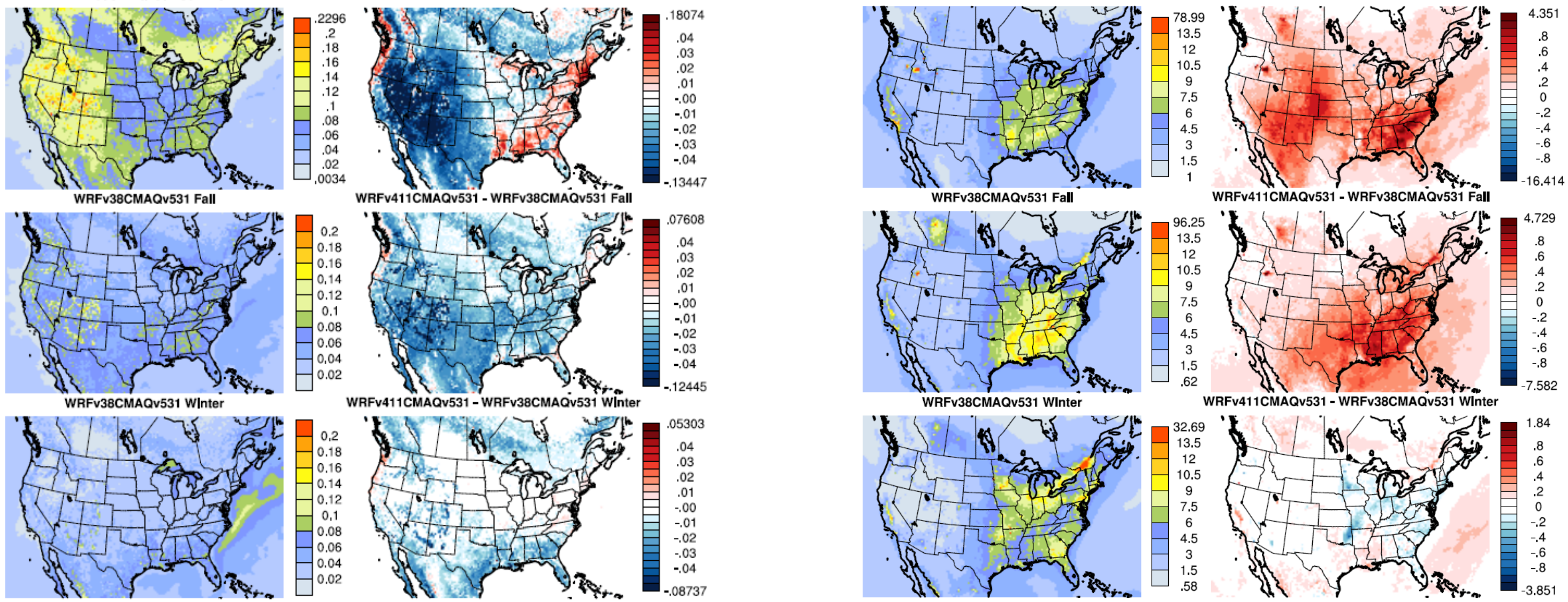

Figure S62. Seasonal accumulation mode deposition velocity (VMASSJ; $\mathrm{cm} \mathrm{s}^{-1}$; left) and $\mathrm{PM}_{2.5}$ concentration $\left(\mu \mathrm{g} \mathrm{m}^{-3}\right)$ for the CMAQ531_WRF38_M3Dry_BiDi simulation along with the difference in VMASSJ and $\mathrm{PM}_{2.5}$ concentration between the CMAQ531_WRF38_M3Dry_Bidi and CMAQ531_WRF411_M3Dry_BiDi simulations (WRF411 - WRF38). 


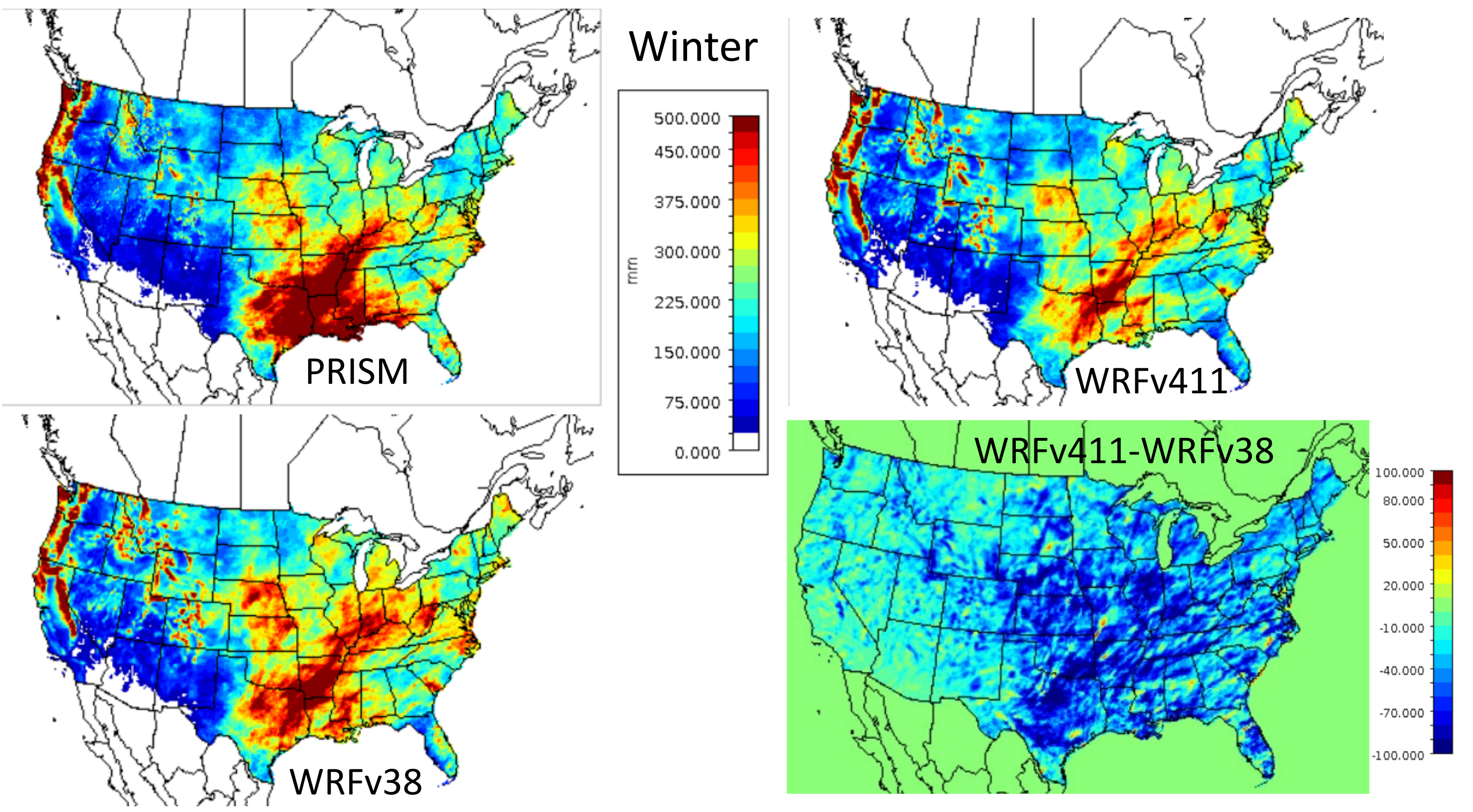

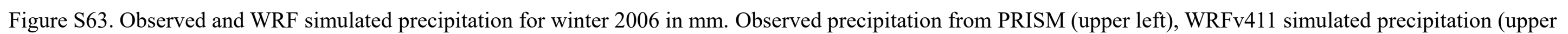
right), WRFv38 simulated precipitation (lower left), and the difference between WRFv411 and WRFv38 (WRFv411 - WRFv38) precipitation (lower right). 


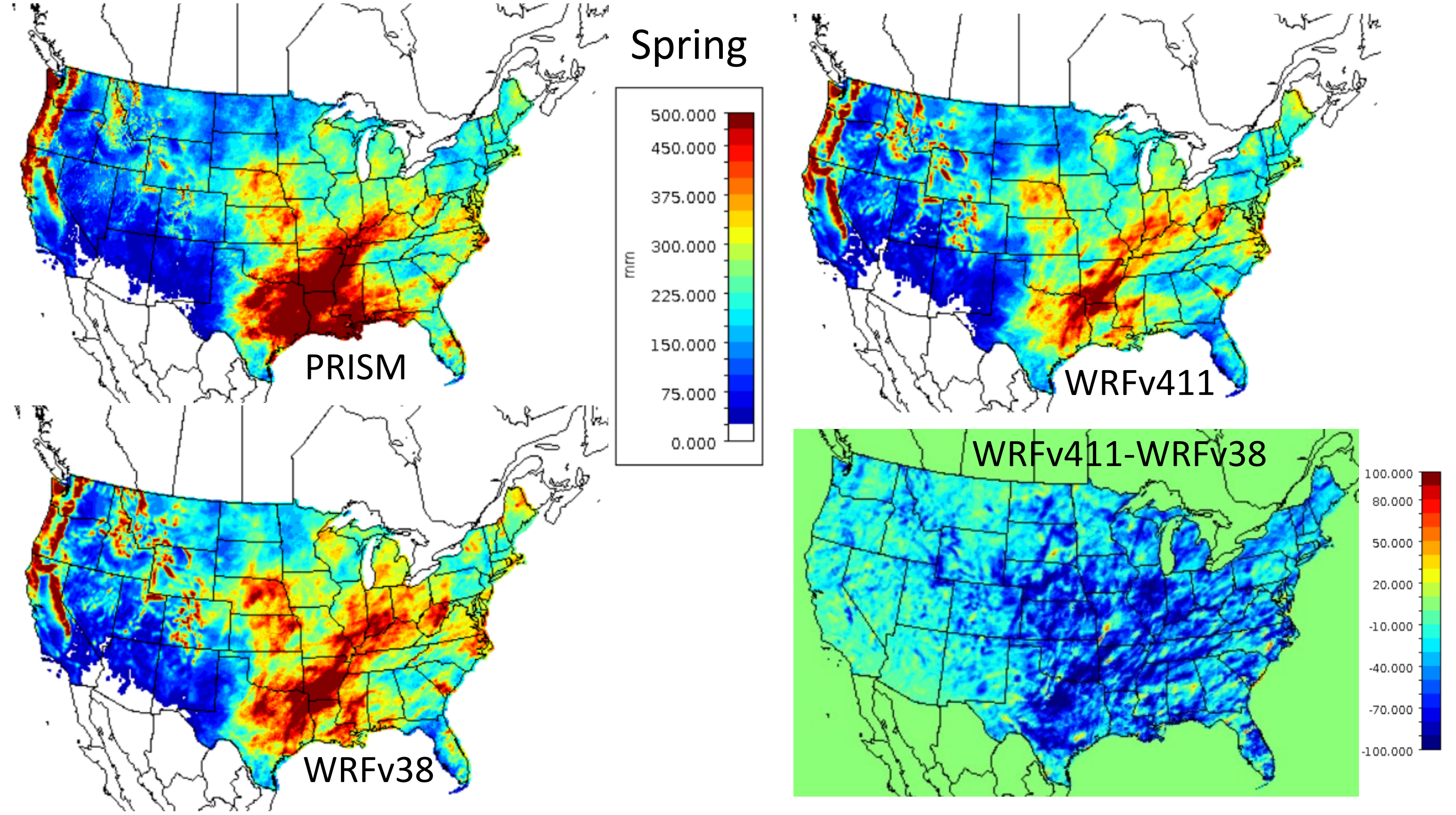

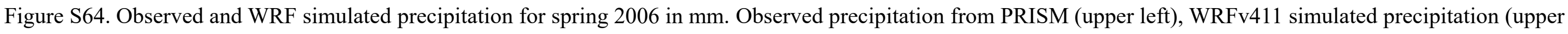
right), WRFv38 simulated precipitation (lower left), and the difference between WRFv411 and WRFv38 (WRFv411 - WRFv38) precipitation (lower right). 


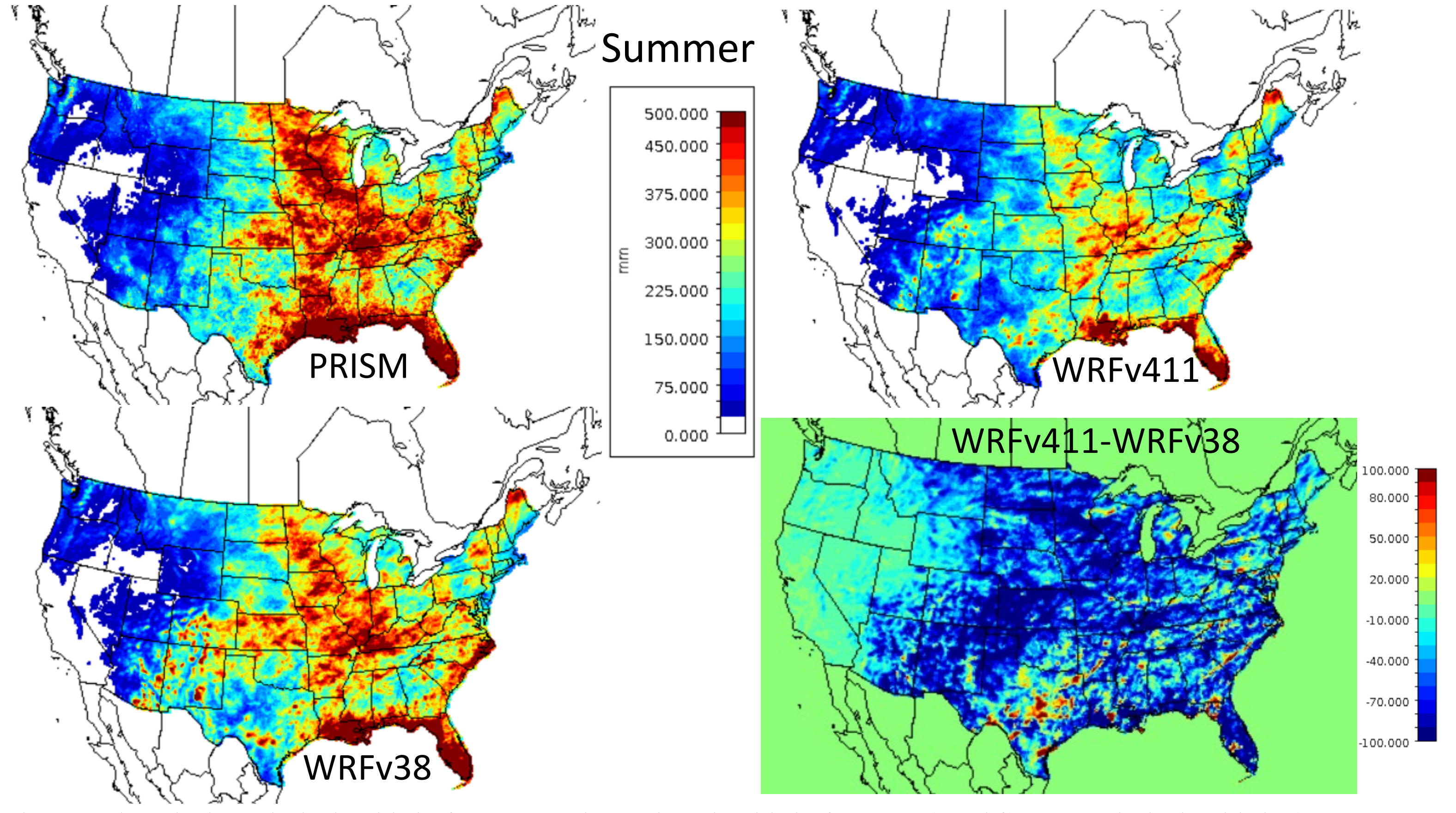

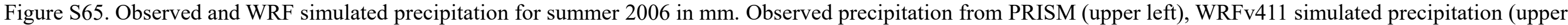
right), WRFv38 simulated precipitation (lower left), and the difference between WRFv411 and WRFv38 (WRFv411 - WRFv38) precipitation (lower right). 


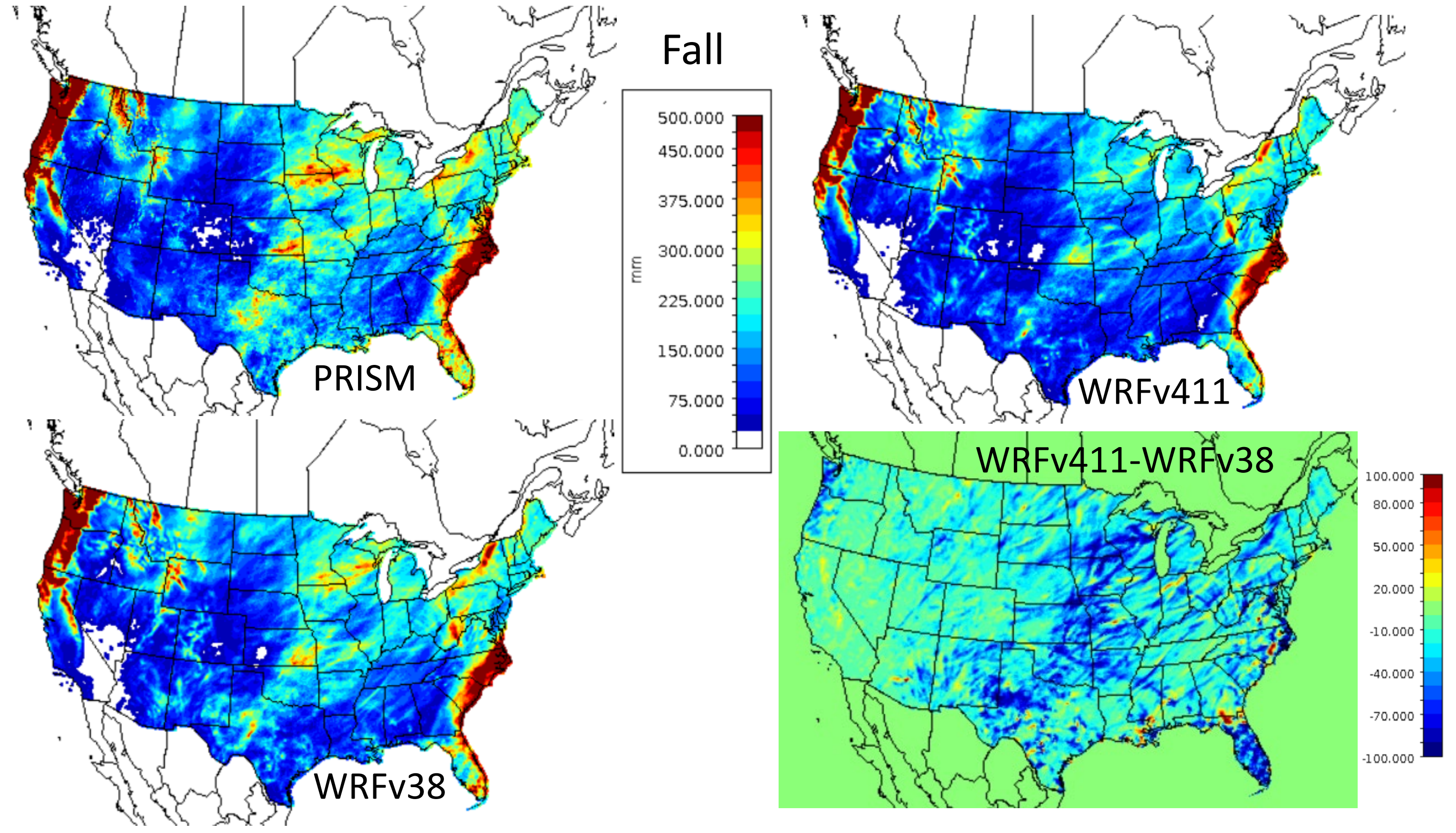

Figure S66. Observed and WRF simulated precipitation for fall 2006 in mm. Observed precipitation from PRISM (upper left), WRFv411 simulated precipitation (upper right), WRFv38 simulated precipitation (lower left), and the difference between WRFv411 and WRFv38 (WRFv411 - WRFv38) precipitation (lower right). 